\title{
O CUIDADO EM FAMÍLIA SOB O OLHAR DO IDOSO
}

\section{MÁRCIA MARIA PORTO ROSSETTO MAZZA}

Tese apresentada ao Programa de Pós Graduação em Saúde Pública da Faculdade de Saúde Pública da Universidade de São Paulo, para a obtenção do título de Doutor em Saúde Pública

Área de Concentração: Serviços de Saúde Pública

Orientador: Prof. Dr. Fernando Lefèvre

\section{SÃO PAULO}


È expressamente proibida a comercialização deste documento tanto na sua forma impressa como eletrônica. Sua reprodução total ou parcial é permitida exclusivamente para fins acadêmicos e científicos, desde que na reprodução figure a identificação do autor, título, instituição e ano da tese/dissertação. 
Aos meus pais, que me permitiram conhecer o verdadeiro significado de Cuidar em Família.

Ao meu amor, Renato, amigo de todas as horas e momentos difíceis, que torce por mim e muitas vezes me ajuda a superar os obstáculos.

Aos meus filhos tão queridos: Marcelo, Henrique e Renato que sempre em silêncio me entenderam e me apoiaram nos momentos de angústia e tensão.

... E a Deus e à Nossa Senhora, que sem Eles nada seria possível... 


\section{AGRADECIMENTOS}

Ao meu orientador Prof. titular Fernando Lefèvre, por me estimular a ousar e a acreditar que sempre é possível realizar os sonhos que julgamos impossíveis.

À minha amiga tão querida Dra. Neusa Guaraciaba dos Santos, presente nas horas de tensão e aflição me amparando e estimulando.

À Profa. Dra. Alice Moreira Derntl, solícita e questionadora a favorecer sempre a reflexão sobre as questões do envelhecimento e da velhice.

Ao meu filho Henrique, que com muita paciência e disposição me auxiliou na formatação deste trabalho.

Às amigas Luciana X. Junqueira, Maria Cristina Bernat e Maria de Fátima e Souza, que ao longo destes anos como parceiras de profissão me auxiliaram em assuntos da nossa prática cotidiana de cuidados.

À Maria Lúcia E. de Faria Ferraz, pela delicadeza e precisão no auxílio da correção das Referências Bibliográficas.

À Liliane Alexandra da Costa e Gisele Luiza Cano de Oliveira que com muita disposição e presteza me auxiliaram na busca das Referências Bibliográficas.

À Profa. Mel amiga de longa data e responsável pela tradução deste trabalho a minha gratidão.

À direção do Centro de Saúde na figura da Profa. titular Ana Cristina D`Tanaka, que sempre nos estimula a sonhar e a realizar nossos sonhos.

À Dra. Sueli M. P. B. R. Silva, tão paciente e acolhedora nos meus questionamentos. 
Aos geriatras do Centro de Saúde, Dra. Ana Catarina R. Quadrante, Dr. João Paulo N. Ribeiro e Dr. Marcel Hiratsuka que muito contribuíram nos meus infindáveis questionamentos junto aos idosos e seus familiares.

À querida Nolinha, que nos seus 92 anos é prova verídica do envelhecimento saudável e digno.

A todos os funcionários do Centro de Saúde, pela paciência e torcida por mim.

E, por fim a todos os idosos e seus familiares, atores principais deste trabalho, meu agradecimento especial e minha eterna gratidão e respeito. 


\section{RESUMO}

Rossetto Mazza, MMP. O Cuidado em Família sob o Olhar do Idoso. [Tese de Doutorado]. São Paulo: Faculdade de Saúde Pública da USP; 2008.

Esta tese é uma continuação da investigação iniciada em meu trabalho de mestrado desenvolvido em 2002, cujo foco dirigiu-se ao cuidador familiar, figura central de atenção ao idoso no domicílio. Este estudo se propôs a estudar como se estabeleceram as relações de cuidado entre o cuidador familiar e o idoso, desviando o olhar deste cuidador e focalizando o olhar no idoso, podendo, com isto, estabelecer a contrapartida para o entendimento desta dinâmica. O objetivo foi identificar o significado, para a pessoa idosa, portadora de alguma incapacidade funcional, que caracterize alguma forma de dependência, sobre o cuidado que a ela é prestado pelo seu cuidador familiar, e identificar a representação social desta pessoa idosa, com referência ao seu cuidador familiar. Foram entrevistados 31 idosos na faixa etária de 65 a 95 anos, matriculados no Centro de Saúde Escola Geraldo de Paula Souza, da Faculdade de Saúde Pública - USP, pertencentes à região de Pinheiros, cidade de São Paulo. A metodologia utilizada foi a qualitativa, usando a teoria da representação social, e a estratégia metodológica para a análise das entrevistas foi o discurso do sujeito coletivo-DSC. Diferentes representações sociais foram extraídas dos depoimentos. Quanto ao significado do cuidado foram referidos: o afeto que recebiam do seu cuidador; a vocação do cuidador para executar o cuidado; a solidão que sentiam; a obrigação/retribuição; o desgaste/tensão, e a troca de papéis. As representações quanto ao julgamento do cuidador e do cuidado foram tanto atributos exclusivos do cuidador quando se referiram à sua competência e eficiência, como atributos dos próprios idosos quando justificaram ser independentes e fáceis de cuidar. Em contraposição, ao reconhecimento de sua dependência do cuidador ao enumerar suas fragilidades; à importância deste cuidador quando asseguraram não terem mais ninguém, só ele; e outras alternativas de cuidado como: contar com a família como provedora de auxílio; procurar outro cuidador; ir para instituição de longa permanência, 
como asilo/casa de repouso; contar com a ajuda de Deus; importância do empregado doméstico na ajuda do cuidado; morar sozinho, apesar das fragilidades; contar com o amparo dos amigos e do serviço de saúde. Para tais idosos a família é a instituição mais valorizada para executar o cuidado, na hipótese de não haver mais o cuidador principal. Reconhecem a dificuldade da prestação do cuidado para a vida de seu familiar e a dificuldade de encontrar outro cuidador para se responsabilizar por eles. A preservação da sua autonomia e independência são buscas contínuas no cotidiano de suas vidas. Através dos discursos dos idosos foi possível compreender suas necessidades, anseios, desejos, possibilitando uma reflexão sobre o envelhecimento e suas implicações.

Descritores: idoso; cuidador familiar; família; promoção de saúde; envelhecimento. 


\begin{abstract}
Rossetto Mazza, MMP. O Cuidado em Família sob o Olhar do Idoso./ Caretaking in the family from the perspective of the elder. [Thesis]. São Paulo (BR): Faculdade de Saúde Pública da USP; 2007.

This thesis is a sequence of the investigation started in my M.A. dissertation developed in 2002, which focus was directed to the caregiver, the central element in the attention to the elders in the household. This study aimed at the study of the way the care relations family caregiver-elder take place shifting the focus to the elder so as to make possible the establishment of the counterpart for the understanding of such dynamics. The objective was twofold: the identification of the meaning, for an elder bearing one or more functional handicaps that characterize some form of dependence, of the care given to him by his family caregiver and also the identification of the social representation of this aging person concerning this caregiver. 31 elders aged 65 to 95 enrolled in the Centro de Saúde Escola Paula Souza of the School of Public Health - USP, residents in the Pinheiros Region of São Paulo were interviewed. A qualitative methodology based on the theory of social representation was used and the methodological strategy utilized for the analysis of the interviews was the Collective Subject Discourse Analysis CSDA. Different social representations were drawn from the statements. Concerning to the meaning of the care were mentioned: affection they received from their caregiver; the vocation of the caregiver to deliver the attention; the loneliness they felt; the obligation/retribution; the wearing out/tension and the role exchange. The representations relating to the judgment of the caregiver and care were both exclusive attributes of the caregiver with regard to his competence and efficiency, as their own attributes when they referred being independent and easy to be taken care of. In contraposition, to the recognition of their dependence of the caregiver when they enumerated their fragilities; the importance of this caregiver; when they assures having no one but him; and other alternatives of care such as: counting on the family as care
\end{abstract}


provider; seek another caretaker; go to long term stay institution, like a nursing home/rest home; counting on God's help; importance of the house maid for the help in the care; living alone, despite the frailties; confiding on the help of friends and health service. For these elders the family is the most valued institution to carry out the assistance, in case of the absence of the main care caregiver. They recognize the difficulty of care giving in the life of his relative and also the difficulty in finding another caregiver to take responsibility over them. The preservation of their own autonomy and independence are continually sought in their daily lives. From the discourse of the elders it was possible to understand their needs, wishes and desires, which make possible a reflection on aging and its implications.

Descriptors: elder; family caregiver; family; health promotion; aging. 


\section{ÍNDICE}

1. INTRODUÇÃOO 12

1.1. O ENVELHECIMENTO 12

1.2. A CAPACIDADE FUNCIONAL COMO DETERMINANTE DO CUIDADO17

1.2.1 Dependência Funcional 19

1.3. A FAMÍLIA DO IDOSO: O CUIDADOR 23

2. JUSTIFICATIVA 29

3. OBJETIVOS 32

4. MÉTODO 33

4.1 DEFINIÇÕES 33

4.2. TEORIA DA REPRESENTAÇÃO SOCIAL 34

4.2.1. Conceito de Representação Social para Alguns Pesquisadores 37

4.3. TÉCNICA DE ANÁLISE DOS DADOS - DISCURSO DO SUJEITO COLETIVO -DSC - $\quad 39$

4.3.1. Figuras Metodológicas $\quad 41$

4.3.2. Atributos Quantitativos do DSC 42

4.4. PROCEDIMENTOS METODOLÓGICOS 42

4.4.1. População de Estudo $\quad 42$

4.4.2. Local do Estudo $\quad 44$

4.4.3. Coleta de Dados $\quad 44$

4.4.3.1. Pré-Teste, Elaboração do Instrumento Definitivo 44

4.4.3.2. Instrumento Definitivo 45

4.4.3.3. Realização das Entrevistas $\quad 45$

4.4.3.4. Organização e Análise dos Dados 46

5. RESULTADOS 48

5.1. CARACTERIZAÇÃO DA REGIÃO 48

5.2. CARACTERIZAÇÕES DOS IDOSOS DO ESTUDO

5.3. DISCURSOS DO SUJEITO COLETIVO 63

5.4. ANCORAGENS DOS DISCURSOS 93 
$\begin{array}{ll}\text { 6. DISCUSSÃO } & 96\end{array}$

6.1. ALGUMAS CONSIDERAÇÕES PRELIMINARES 98

6.2. DISCUSSÃO PROPRIAMENTE DITA 100

6.2.1. Ancoragens 137

6.3. OBSERVAÇÕES SOBRE A EXPERIÊNCIA DE ABORDAGEM COM OS IDOSOS ENTREVISTADOS 142

7. CONCLUSÕES 146

8. CONSIDERAÇÕES FINAIS 149

9. REFERÊNCIAS 158

$\begin{array}{lr}\text { ANEXOS } & 170\end{array}$

$\begin{array}{ll}\text { Anexo } 1 \text { - Termo de Consentimento Livre e Esclarecido } & 170\end{array}$

$\begin{array}{ll}\text { Anexo } 2 \text { - Roteiro de Entrevista } & 171\end{array}$

$\begin{array}{ll}\text { Anexo } 3 \text { - Teste O`Clock } & 172\end{array}$

$\begin{array}{ll}\text { Anexo } 4 \text { - Ficha de Identificação do Idoso } & 173\end{array}$

Anexo 5 - Instrumento de Avaliação da Capacidade Funcional do Idoso 174 


\section{Lista de Tabelas}

Tabela 1 - Indicadores educacionais dos chefes de família da Região de Pinheiros e do Município de São Paulo, 2004

Tabela 2 - Equipamentos municipais de assistência social da Região de Pinheiros e do Município São Paulo, 2004.

Tabela 3 - Indicadores socioeconômicos dos chefes de família da Região de Pinheiros e do Município de São Paulo, 2004.

Tabela 4 - Número e proporção de idosos entrevistados e matriculados no CSEGPS, segundo sexo, Região de Pinheiros, São Paulo, 2005.

Tabela 5 - Número e proporção de idosos entrevistados e matriculados no CSEGPS, segundo faixa etária, Região de Pinheiros, São Paulo, 2005

Tabela 6 - Número e proporção de idosos entrevistados e matriculados no CSEGPS, segundo grau de instrução, Região de Pinheiros, São Paulo, 2005

Tabela 7 - Distribuição dos recursos financeiros dos idosos entrevistados e matriculados no CSEGPS, Região de Pinheiros, São Paulo, 2005

Tabela 8 - Demonstração do grau de parentesco dos idosos, entrevistados e matriculados no CSEGPS, com seus cuidadores familiares, Região de Pinheiros, São Paulo, 200559

Tabela 9 - Avaliação da capacidade funcional dos idosos entrevistados e matriculados no CSEGPS, Região de Pinheiros, São Paulo, 2005 


\section{Lista de Figuras}

Figura 1 - Mapa do Município de São Paulo, destaque para a região oeste, Pinheiros, São Paulo, 2004

Figura 2 - Distritos administrativos de Pinheiros, região oeste, Pinheiros, São Paulo 2004

Figura 3 - Empregos por tipo de atividade, região oeste, Pinheiros, São Paulo, 200451

Figura 4 - Principais causas de morte região oeste, Pinheiros, São Paulo, 2004

Figura 5 - Pirâmide populacional da região oeste, Pinheiros, São Paulo, 2004 


\section{INTRODUÇÃO}

\subsection{O ENVELHECIMENTO}

Melhor qualidade para o envelhecimento populacional é uma das principais conquistas sociais do século XX, e seguramente foi neste século que se deu o estudo da velhice e do processo de envelhecimento (PAPALÉO-NETO 2002), com a ocorrência de várias transformações na sua experiência (DEBERT 1999), mas “...é sempre percebido e entendido de várias maneiras diferentes levando sempre em conta as variações culturais, podendo se referir a processos biológicos, aparência física, eventos de desengajamento da vida social dentre outros" (CAMARANO, 2002, p.5).

Para tratar do envelhecimento como preocupação social será necessário, como bem acentua DEBERT 1999, “...buscar acessos privilegiados para dar conta de mudanças culturais nas formas de pensar e de gerir a experiência cotidiana, o tempo e o espaço, as idades e os gêneros, o trabalho e o lazer, analisando, de uma ótica específica, como uma sociedade projeta sua própria reprodução" (p.13). Neste sentido é pertinente a observação de ERIKSON 1999 quando adverte que "sem um ideal culturalmente viável da velhice, a nossa civilização realmente não possui um conceito da totalidade da vida" (p.96).

É sabido que o envelhecimento traz vulnerabilidades, perdas sociais importantes, aparecimento de novos papéis (como ser avós), agravamento das doenças crônicas e degenerativas, perdas de entes queridos. Sabe-se também que este processo difere de sexo, grupo social, cor, raça, localização geográfica e que pode ser minimizado com políticas públicas eficazes e eficientes. (CAMARANO e PASINATO, 2004).

RAMOS 2003 é mais enfático quando salienta que "a velhice é um período da vida com uma alta prevalência de doenças crônicas não transmissíveis - DCNT, limitações físicas, perdas cognitivas, sintomas depressivos, declínio sensorial, acidentes e isolamento social” (p.796). 
Para DUARTE 2001, “o envelhecimento é considerado uma das crises no ciclo vital... é uma situação de mudança que requer adaptações do próprio indivíduo que envelhece e do seu sistema familiar que igualmente envelhece" (p.16).

BALTES e SILVERBERG 1995 acreditam que estas mudanças “...diferem em ritmo, intensidade e escopo..."(p.100) e constituem as principais tarefas - chamadas de tarefas evolutivas da quarta fase da vida - com que os idosos se deparam. São elas: "o ajustamento à aposentadoria e a perda de papéis, o aumento dos problemas de saúde e das incapacidades físicas, e por fim, a admissão da própria finitude” (p.101).

O estudo do envelhecimento e da velhice ficou por muito tempo restrito apenas aos aspectos biológicos e individuais, restringindo-se à esfera familiar.

No princípio foi considerado como um processo homogêneo, porque as doenças crônicas advindas do envelhecimento são comuns na maioria das pessoas desta faixa etária (FONTE, 2002).

CAMARANO e PASINATO 2004 esclarecem que ainda na década de 1990 do século XX, nos países em desenvolvimento, o envelhecimento era visto como processo homogêneo com necessidades e experiências comuns, tendo como visão predominante da sociedade associar o envelhecimento à dependência e aos problemas sociais, chegando a considerá-lo uma ameaça ao futuro das economias, e da própria democracia.

As autoras complementam que gradualmente durante essa década houve uma mudança de visão de um subgrupo vulnerável e dependente para um segmento ativo e atuante, que deve ser incorporado na busca do bem-estar de toda a sociedade (p. 257).

Na visão de DEBERT 1999 “a transformação do envelhecimento em objeto de saber científico põe em jogo múltiplas dimensões como o desgaste fisiológico e o prolongamento da vida, o desequilíbrio demográfico e o custo financeiro das políticas sociais" (p.32).

Em contraposição, atualmente o que se preconiza é "o fenômeno do envelhecimento é multifacetado e multifatorial" (PAPALEO-NETO, 2002), não podendo mais ser considerado como um fenômeno homogêneo onde as histórias de vida, estilos próprios de sobrevivência e necessidades distintas fazem de cada idoso um ser 
diferente, com tipos diferentes de relações familiares e de enxergar a vida e o próprio envelhecimento.

Ele não pode ter uma conotação de homogeneidade de sua representação, pois a importância e o status do idoso dependem da posição que ele assumiu perante a sua família e no meio em que viveu. (DEBERT 1999).

PASCHOAL 2002 frisa que "como o envelhecimento é uma experiência heterogênea, cada indivíduo pautará sua vida de acordo com padrões, normas, expectativas, desejos, valores e princípios diferentes" (p. 82).

RAUTH e RODRIGUES 2002 referem-se que "cada pessoa e cada geração experimentam a velhice de forma diferente dependendo de uma constelação de fatores biológicos e ambientais" (p. 107).

Além destas opiniões sobre o fenômeno do envelhecimento, é necessário também fazer o deslocamento do enfoque da velhice centrado nos aspectos biológico e individual para os enfoques social e político, quando será exigida do Brasil uma reestruturação total de suas políticas econômica, social, cultural, educacional, de previdência social (FONTE, 2002).

As diretrizes internacionais da Organização das Nações Unidas - ONU - para o envelhecimento, em 2002, que ocorreram em Madri, na 2a Assembléia Mundial sobre o Envelhecimento, conceberam uma nova idéia de velhice implícita no conceito de envelhecimento ativo ou produtivo associado à inclusão social, ou seja, à inserção social do idoso na comunidade.

A Organização Mundial da Saúde - OMS - definiu como envelhecimento ativo “o processo de otimização das oportunidades para a saúde, a participação e a segurança, a fim de realçar a qualidade de vida à medida que as pessoas envelhecem”. Os agentes que promovem o envelhecimento ativo são: o indivíduo, os familiares e amigos, os serviços comunitários e o Estado (OPAS, 2002 p. 8).

Para a ONU, "a estratégia é a garantia de um envelhecimento com segurança e dignidade, considerando as pessoas idosas como cidadãos com plenos direitos” “...será 
necessário buscar novos espaços nas estruturas sociais e reforçar o debate sobre as atribuições do Estado" (FONTE, 2002 pp. 3 e 5).

Os avanços do Plano de Madri foram: a importância da contribuição dos idosos na sociedade; os governos nacionais deverão insistir nas parcerias com membros da sociedade civil e do setor privado para a execução de medidas que visem ao bem estar da população idosa, cabendo a eles indicar as parcerias, estabelecer as responsabilidades de cada parte, sem deixar de considerar a parte que lhes cabe, a consideração da dimensão de gênero com a preocupação, em particular, com as mulheres (CAMARANO e PASINATO, 2004).

No Brasil, o grande avanço das políticas de proteção social à população idosa deveu-se à promulgação da Constituição de 1988, a qual especificou o papel do Estado na proteção ao idoso, mas também elegeu a família como a principal responsável pela execução dos cuidados, podendo ser criminalizada caso não os execute.

O Estado, através do reconhecimento do seu papel de protetor, criou em 1994 a Política Nacional do Idoso - PNI - cujo princípio fundamental era: “O idoso é um sujeito de direitos e deve ser atendido de maneira diferenciada em cada uma das suas necessidades: físicas, sociais, econômicas e políticas" (idem, 2004, p. 269). Seguindo essa linha de proteção, em 1999 o Ministério da Saúde elaborou a Política Nacional de Saúde do Idoso - PNSI - que apresentou dois eixos norteadores: medidas preventivas, com especial destaque para a promoção de saúde; e atendimento multidisciplinar específico para este contingente populacional. Em 2003, início do século XXI, o Congresso Nacional aprovou o Estatuto do Idoso, documento que contém 118 artigos versando sobre diversas áreas dos direitos fundamentais e das necessidades de proteção dos idosos, reforçando as diretrizes da Política Nacional do Idoso (idem, 270).

$\mathrm{O}$ avanço das medidas de proteção social referentes à população idosa, empreendidas pelo governo brasileiro, sofreu e sofre grande influência das políticas internacionais implementadas principalmente pela ONU, OMS e OPAS pondo em prática este novo paradigma do envelhecimento ativo e produtivo, assimilando o seu Plano de Ação e executando seus três princípios, a saber: participação ativa dos idosos 
na comunidade; fomento da saúde e bem-estar na velhice, com promoção do envelhecimento saudável; e criação de um entorno propício e saudável ao envelhecimento.

Faz-se necessário também ressaltar a importância das diferenças regionais brasileiras no que se refere aos níveis de saúde, de educação, de oportunidades, e mesmo de expectativa de vida, que são muito diferentes, o que é reafirmado por RODRIGUES e RAUTH 2002, quando reconhecem: "Não existe uma velhice, mas velhices distintas no Brasil".

$\mathrm{O}$ adequado atendimento deste segmento populacional tão heterogêneo é difícil nas condições em que se encontra o País, que apresenta um sistema social de amparo muito deficiente e obsoleto. O que verificamos na prática é que os idosos brasileiros são carentes do setor saúde, mas muito mais carentes do amparo social do Estado, pois a maioria desta população possui um nível socioeconômico aquém do desejado. Confirmando isto, CAMARANO e PASINATO 2004 advogam: que "as políticas públicas são importantes pilares na constituição do bem-estar da população idosa" (p.16).

Com a ausência de políticas de igualdade de oportunidades sociais adaptadas a cada localidade geográfica, o atendimento à população idosa no Brasil corre sérios riscos de ter êxito. RAMOS 2002 destaca: "o grande desafio para o século XXI é o de cuidar de mais de 32 milhões de idosos, a maioria com baixo nível socioeconômico e educacional ao lado de uma alta prevalência de doenças crônicas não transmissíveis e incapacitantes" (p. 77).

Este desafio não é só do Estado, mas também de toda a sociedade e dos profissionais e estudiosos do envelhecimento, que ao se engajarem nesta tarefa estarão contribuindo para uma melhor qualidade de vida e dignidade para todos os cidadãos brasileiros.

A situação da velhice e do envelhecimento no Brasil não pode mais ser ignorada pela nossa sociedade e pelo Estado. RAMOS 2002 pondera que "para corrigir o descompasso entre a realidade demográfico-epidemiológica e o sistema de saúde em 
médio prazo será necessário estabelecer indicadores de saúde capazes de identificar idosos de alto risco e orientar ações concentradas de promoção de saúde e manutenção da capacidade funcional. Estas medidas deverão contar com as ações práticas dos profissionais que atuam no nível primário de atenção com um custo-benefício aceitável para os administradores da saúde" (p. 77).

No estabelecimento dos programas de atenção primária e de promoção à saúde para os idosos, o objetivo principal deverá ser a manutenção da sua capacidade funcional a fim de prevenir e/ou retardar sua dependência, propiciando deste modo a sua independência e permanência pelo maior tempo possível na comunidade.

Dados do Instituto Brasileiro de Geografia Estatística - IBGE - referentes ao censo demográfico de 2000, possibilitaram mensurar o grau de autonomia das pessoas, e foi constatado que $26,8 \%$ dos idosos brasileiros declararam ter alguma dificuldade em caminhar e subir escadas, sendo as mulheres as mais afetadas por estas dificuldades (CAMARANO, KANSO, MELLO, 2004).

\subsection{A CAPACIDADE FUNCIONAL COMO DETERMINANTE DO CUIDADO}

A Política Nacional do Idoso prescreve que a capacidade funcional é um novo conceito de saúde para instrumentalizar e operacionalizar a atenção de saúde do idoso. É através dela que os profissionais que trabalham com os idosos têm condições de medir e determinar o grau de independência e de autonomia desses idosos. A perda dessas habilidades físicas e mentais necessárias para a realização das atividades vida diárias AVDs - e das atividades instrumentais de vida diária - AIVDs - constitui o principal problema dos idosos.

No dizer de RAMOS 2002 "a capacidade funcional surge, portanto, como um novo paradigma de saúde, particularmente relevante para o idoso," entendendo que "saúde dentro dessa nova ótica é a resultante da interação multidimensional entre saúde 
física, mental, independência nas atividades de vida diária (AVD), integração social, suporte familiar e independência econômica" (p. 75).

O mesmo autor admite que para o idoso a saúde não é mais medida pela presença ou ausência de doença, mas sim pela preservação de sua capacidade funcional (idem, 2003, p. 793).

NERI (2001) explica que a definição operacional de capacidade funcional "diz respeito ao grau de preservação da capacidade de realizar as atividades básicas de vida diária ou de autocuidado (AVD), e ao grau de capacidade para desempenhar as atividades instrumentais de vida diária (AIVD), apresentadas pelo indivíduo.” (p. 17)

Cerca de $40 \%$ dos indivíduos com mais de 65 anos necessitam de algum tipo de ajuda para realizar pelo menos uma atividade instrumental de vida diária (AIVD), como fazer compras, cuidar das finanças, preparar refeições, arrumar a casa, e 10\% necessitam de ajuda na realização de atividades de vida diária (AVD), como tomar banho, alimentar-se, vestir-se, ir ao banheiro, sentar-se e levantar-se de cadeiras e camas (MPAS, 2000; LITVOC e DERNTL, 2002).

Para CHAIMOWICZ (1997), “as questões da capacidade funcional e autonomia do idoso podem ser mais importantes que a própria questão da morbidade, pois se relacionam diretamente à qualidade de vida.” (p. 191).

O envelhecimento saudável está pautado tanto na manutenção e preservação da capacidade funcional como na qualidade de vida de que dispõem estes indivíduos.

PASCHOAL 2002 diz: "Se os indivíduos envelhecerem com autonomia e independência, com boa saúde física desempenhando papéis sociais, permanecendo ativos, desfrutando de senso de significado pessoal, a qualidade de sua vida pode ser muito boa" (p. 79).

A tarefa mais importante para todos os profissionais que trabalham com os idosos é a preservação da capacidade funcional. O conhecimento real desta capacidade funcional permitirá traçar o plano de cuidados de que necessitará o idoso e sua família. Sabemos através da literatura que quanto mais dependente for o idoso de cuidados, 
maior será o ônus para a família, para os cuidadores, para os profissionais e para o Estado.

\subsubsection{A Dependência Funcional}

Anita L. Néri é a pesquisadora do envelhecimento que, a nosso ver, melhor traduziu e resumiu os vários aspectos da dependência do idoso.

O artigo de BALTES e SILVERBEG 1995, de tradução desta pesquisadora, confirma que "as dependências da velhice resultam tanto de mudanças biológicas quanto de mudanças nas exigências sociais," havendo, portanto, "uma interação entre os fatores biológicos e os ambientais" (p. 102).

Com o envelhecimento há o aumento das perdas físicas e sociais e o aparecimento de incapacidades, acarretando uma ameaça à autonomia do idoso, e com isto "a segurança propiciada por um ambiente acolhedor assim como a autonomia permitida por um ambiente estimulador são necessárias ao bem-estar do idoso" (idem p.102). Não podemos deixar de considerar como referem os autores que "a segurança e a autonomia propiciadas pelo ambiente são em grande parte determinadas pelas competências e recursos da pessoa, sendo esta autonomia desafiada pelas limitações físicas, sociais, psicológicas e econômicas impostas por um corpo mais vulnerável e cansado" (idem p. 102).

A seguir de maneira bem resumida assinalaremos, de conformidade com essas autoras, as principais dependências do ser humano.

Dependência Estruturada: segundo as teorias funcionalistas sobre o controle social, a dependência estruturada é determinada primariamente pela participação do ser humano no processo produtivo. "A perda do trabalho e/ou da aposentadoria gera a dependência estruturada. A cultura, na sua essência, estabelece as bases para a dependência, na medida em que sua estrutura social requer dependência de certos grupos da população para poder funcionar" (idem p. 102). Alguns autores atribuem à sociedade 
a responsabilidade pela dependência do idoso quando lembram que os serviços sociais existentes são fragmentados, conduzindo-o a menor autonomia e escolha e tornando-o dependente do sistema.

Dependência Física: este tipo de dependência possui várias definições de diferentes autores, podendo ser denominado de incapacidade funcional, desamparo prático, ou incapacidade individual para realizar atividades da vida diária.

Para medir o grau desta dependência ela pode ser avaliada, dependendo do número de incapacidades apresentadas pelo idoso e pela escolha das variáveis como, por exemplo: idade, gênero, classe social, etc.

O idoso acometido por transtornos degenerativos cerebrais, por derrame cerebral ou outra doença incapacitante possui uma dependência física mais exacerbada, porém as autoras ponderam que nem sempre a incapacidade orgânica é condição necessária e suficiente para a dependência, embora na percepção social o idoso com dependência física seja considerado incompetente para o sistema. "Existe uma ligação direta entre competência e autonomia e entre incompetência e dependência, sem se considerar a possibilidade de variações entre seus extremos" (idem, p. 103).

Dependência Comportamental: é uma das dependências mais temidas pelo idoso, pois ao contrário da dependência física, que tem uma real incompetência física, a dependência comportamental é socialmente induzida independentemente do nível de competência do idoso. Ela é medida pelo ambiente onde vive o idoso, que poderá ser negligente ou superprotetor, levando em ambos os casos à sua dependência comportamental. Para as autoras, “o ambiente espera incompetência e dá ajuda, mesmo que isso seja desnecessário ou indesejável, sob pena de ser considerado como irresponsável e negligente... Em contraste, um ambiente de baixa exigência é um ambiente caracterizado por superproteção, que também resulta em dependência" (idem, p. 104). Freqüentemente a dependência comportamental é precedida pela dependência física. 
A expectativa é de que há necessidade de se construir mudanças nas condições ambientais que possam encorajar e incentivar as competências dos idosos, e não estimular a incompetência gerando dependência.

Como conclusão, as autoras comentam que "de modo geral, a dependência é socialmente induzida na velhice e não faz justiça às capacidades que o idoso ainda possui. Por outro lado, há a associação de dependência com envelhecimento bemsucedido onde há a exigência de adaptação do equilíbrio entre as perdas e ganhos que se tornam cada vez mais negativas," levando o idoso a criar estratégias compensatórias para melhor adaptar-se a elas. ( idem, p. 108).

O exposto acima pode ser confirmado pela pesquisa realizada por SANCHES 2000 sobre a dependência e suas implicações para a autonomia dos idosos, quando estes falam "haver conflito nas relações familiares, embora sejam dependentes para realizar algumas AVDs ou AIVDs, podem sim tomar decisões sobre a sua vida. Referem não haver diálogo e muito menos possibilidade de escolha tendo como conseqüência um cerceamento de ações seja no campo afetivo, intelectual, social e religioso” (p. 50) ...’há um profundo pesar não pela perda funcional, mas pela perda de liberdade de escolha, do poder decisório, do real sentido de viver" (idem, p. 50)

Para tanto a autora adverte que "...a convivência satisfatória e o bem-estar da pessoa que envelhece em condição de fragilidade demandam que os arranjos familiares se constituam por meio de um processo de respeito aos valores construídos por seus integrantes entre os quais se inclui o idoso"(idem, p. 51).

MEDEIROS e DINIZ 2004 vão mais além quando abordam o termo "deficiência e o envelhecimento" ao apontarem a importância da discussão referente ao modelo social da deficiência, corrente teórica e política iniciada no Reino Unido em 1960, que no Brasil, a partir da década de 1990, vem sendo adotada através dos levantamentos demográficos das pesquisas governamentais onde esta nova corrente muda a forma tradicional de compreensão da questão, ao transferir do indivíduo para a sociedade a responsabilidade pelas desvantagens relacionadas à deficiência. 
A deficiência é entendida como a resultante da combinação de limitações impostas pelo corpo a uma organização social pouco sensível à diversidade corporal. $\mathrm{O}$ principal argumento é que tendo em vista a interseção entre deficiência e envelhecimento, as perspectivas teóricas e políticas do modelo social da deficiência são uma fonte rica de diálogo e inspiração para políticas de bem-estar e de justiça social para os idosos. (p. 7).

Os autores pontuam que numa sociedade ajustada uma pessoa com limitações funcionais pode perfeitamente experimentar a inclusão social. Eles constatam que “...a acumulação de limitações leves de funcionalidade corporal, típica entre os idosos, pode resultar na experiência de grandes deficiências, caso estes vivam em uma sociedade que se organiza de maneira hostil às pessoas com essas limitações" (idem, p. 16).

O envelhecimento da população brasileira, em curto prazo, trará uma grande quantidade de pessoas com diferentes tipos de dependência: leves, moderados ou graves, onde estas condições certamente reduzirão a capacidade desses indivíduos de superar os desafios ambientais, tornando-os idosos deficientes.

BALTES e SILVERBERG 1995 asseveram: “...Na velhice a dependência física é com muita freqüência confundida com dependência para tomada de decisão, o que dá origem a um paternalismo social de perigosas consequiências que justifica fazer tudo em lugar do idoso e negar sua liberdade, autonomia e capacidade de escolha” (p. 109).

RAMOS 2003 também acrescenta que “...na velhice o que está em jogo é a autonomia, ou seja, a capacidade de determinar e executar seus próprios desígnios" (p.794). 


\subsection{A FAMÍLIA DO IDOSO: O CUIDADOR}

A família no Brasil é ainda a principal fonte de suporte principalmente para a população idosa de poder aquisitivo mais baixo, que apresenta mais problemas de saúde e maior dependência para as atividades do dia a dia.

Ao longo dos anos ela vem se modificando, passando de um modelo patriarcal e multigeracional para um modelo de família unigeracional.

Na perspectiva de AQUINO e CABRAL 2002 "por ser uma instituição está estreitamente vinculada às questões sociais, culturais, econômicas e históricas," (p.1056) podendo desta forma estar em constante transformação em sua composição e em seu papel na vida de seus membros.

O modelo antigo de família, composto de pai, mãe, muitos filhos, avós e parentes, tinha a função precípua de cuidar dos doentes, das crianças e dos idosos.

A modernidade trouxe consigo novas possibilidades de avanço tecnológico, e com isto foram aumentadas as possibilidades de acesso aos meios de cultura e de novas oportunidades para todos os membros da família. Desta forma, a estrutura familiar aos poucos vai se modificando. A saída da mulher do seio familiar para o mercado de trabalho, a diminuição da fecundidade, a migração da população para os centros urbanos, o surgimento de novos papéis de gênero e a maior longevidade de seus membros (todos estes fenômenos exaustivamente referidos pelos estudiosos) influenciaram e impulsionaram para o novo modelo de família.

CANO e FERRIANI (2000), em seu estudo bibliográfico sobre a família, citando Romanelli, 1986, caracterizam que "na sociedade brasileira atual, o modelo de família nuclear é hegemônico e visto como ideal a ser seguido pela maioria das pessoas, mas esse modelo tem sofrido fissuras e outros arranjos familiares têm surgido, com o aumento do número de famílias matrifocais como resultado de diversas causas” (p. 31).

Estas modificações também são referidas por MEDEIROS e OSÓRIO 2002, num artigo sobre a composição dos arranjos domiciliares no período de 1978-1998 onde a principal mudança foi a diminuição do peso relativo do modelo de arranjo cujo núcleo é 
o casal, e o aumento do tipo núcleo simples constituído por mulheres, com predominância para mulher com filho com um crescimento de 1,6 vez neste período (idem, 2001).

O número cada vez maior de divórcios, e de segundos ou terceiros casamentos tem influenciado também a mudança desta estrutura nuclear e multigeracional (MIOTO, 1999; KARSCH, 2002), "alterando o perfil de poder e de tomada de decisões dentro das famílias que passam atualmente por uma construção de modelos alternativos de relações e papéis." (DUARTE, 1997, p. 228).

O conhecimento destas mudanças na estrutura familiar deve ser focalizado pois possibilita entender como as famílias que possuem a pessoa idosa na condição de necessitada de cuidados ou de provedor convivem com as dificuldades financeiras, e de saúde, e como os arranjos domiciliares estão se estruturando.

MEDEIROS e OSÓRIO 2001 realçam que "na sociedade brasileira, como em diversas outras, a coabitação tem um forte papel na integração dos membros da família, fazendo que a distribuição de direitos e obrigações entre os membros normalmente seja mais intensa entre aqueles que vivem no mesmo domicílio" (p. 34).

CAMARANO et al 2004 elucidam que na composição das famílias brasileiras nas últimas décadas, mais precisamente no período de 1980 a 2000, aumentou o número de famílias de idosos em relação a famílias com idosos tanto em termos absolutos quanto em termos relativos, apontando para uma redução da sua dependência. A denominação de co-residência é comum no Brasil e em outros países, ocorrendo mais por necessidades financeiras dos filhos, quando retardam sua saída da casa dos pais ou retornam na condição de dependentes. Os motivos apontados são: instabilidade no mercado de trabalho, maior número de anos passados na escola e a instabilidade das relações afetivas.

Do ponto de vista da população idosa, dois fatores são relevantes na determinação da necessidade de co-residência: as condições de saúde e autonomia do idoso e a sua renda sendo utilizada pela família, quando ele perde a sua capacidade laboral. O efeito desses dois fatores é afetado pelas políticas sociais. 
As famílias de idosos caracterizam-se por apresentá-los como chefes ou cônjuges dos domicílios. 1/3 dos seus membros é composto por filhos e 10\% por netos. Estes filhos ou não possuem rendimentos ou os rendimentos são inferiores aos de seus pais. As famílias com idosos distinguem-se por ter idosos mais velhos, com capacidade funcional comprometida, portanto necessitando de ajuda para as atividades cotidianas (idem, p.16).

As autoras enumeram alguns indicadores que evidenciam essas famílias de idosos e com idosos. Nas famílias de idosos houve uma proporção maior de crescimento; estes idosos são 3,6 anos mais jovens; participam mais do mercado de trabalho; houve aumento na proporção de beneficiários da seguridade social, e aumento da porcentagem de mulheres chefes de família. Nas famílias com idosos a proporção cresceu também; os idosos são mais velhos; aumentou a porcentagem de idosos do sexo feminino. Houve melhoria das condições econômicas em ambos os arranjos, onde as melhorias foram devido ao aumento do rendimento médio per capita e pela redução percentual de famílias que recebiam até meio salário mínimo.

Essas autoras observam que "as mudanças demográficas e sociais estão afetando as relações entre as gerações em várias partes do mundo, mas seu impacto não tem significado o enfraquecimento das relações familiares. As famílias têm se mostrado uma instituição resistente" (2003, p. 16). Talvez um dos motivos seja o que AQUINO e CABRAL (2002) resumem como: “...ela é o espaço da intimidade e do segredo, dificilmente compartilhada ou exposta ao olhar externo." Na família ... ainda continua a existir a expectativa de que os (filhos) cuidem dos pais na velhice. "Trata-se da norma de reciprocidade consagrada em todos os contextos sociais" (p. 1056).

FALCÃO et al 2006 também expressam que "o sentimento de pertencer a uma família envolve afeto, liberdade, reciprocidade, histórias compartilhadas, enfim, aspectos inerentes à condição do ser humano que abarcam questões conscientes e inconscientes" (p.62). 
Conforme NERI e LUCENA 2002 "em todo o mundo, a rede de apoio informal composta pela família, pela rede de amigos e por voluntários é a fonte primária de assistência aos idosos" (p. 779).

Podemos assim assegurar que é com ela (família) que os profissionais no cotidiano do cuidado prestado aos idosos contam para prestar assistência a este grupo vulnerável.

A dificuldade na atenção prestada é medida freqüentemente pela dificuldade de interação dos seus membros.

Em uma família onde o cuidador está presente e presta efetivamente o cuidado de que o idoso necessita, sanando suas necessidades fundamentais de sobrevivência, de afeto e de dignidade, os profissionais e os serviços de saúde encontram um parceiro para cuidar deste idoso. Podemos assegurar isto baseados em nossa experiência profissional cotidiana no trabalho com idosos. Verificamos que quando isto não ocorre o idoso está fadado ao abandono na própria família terminando invariavelmente em uma instituição asilar.

DUARTE, 2001 argumenta que "a família cumpre importantes papéis como assegurar bem-estar afetivo e material e absorver o impacto das tensões provocadas pelas próprias crises" (p. 11).

Compartilhamos com ÂNGELO (2000) quando comprova que pensar na família, "é um desafio para os profissionais de saúde. Sobretudo num contexto em que o cuidado está orientado primeiramente para atender às necessidades do indivíduo e não da unidade familiar... Pensar na família é tomá-la como perspectiva... é considerar o contexto familiar no processo de cuidar em saúde... onde todo o processo de viver a vida e as transições da vida está sendo construído a cada dia” (p. 27).

A família do idoso deve ser assistida e amparada para que tenha condições de atender de modo mais eficaz este seu membro vulnerável. A construção conjunta de um sistema de apoio e de uma rede de suporte, tanto de saúde como social, auxiliará esta família, diminuindo com isto os seus custos emocionais e também financeiros. 
Sem este amparo a família e o cuidador do idoso ficam impossibilitados de prestar-lhe o cuidado devido. Em nosso estudo com cuidadores familiares (ROSSETTOMAZZA 2002) constatamos que "sem o devido respaldo esses familiares, por incapacidade de prestar assistência deixam de assistir os idosos de uma forma digna, obrigando-se a lançar mão da institucionalização" (p. 94)

Este suporte deverá estar centrado na figura do cuidador, que é a pessoa que no seu cotidiano com o idoso divide a sua vida e suas dificuldades. Sabemos que na prática este cuidador e sua família estão sozinhos no desempenho das tarefas de cuidado do idoso.

Há muito tempo se fala desta figura tão imprescindível na vida do idoso; o que ela representa para ele, a grande necessidade dela para que o idoso permaneça na sua família e na sua comunidade, como é desgastante e sofrida a prestação do cuidado e, por fim, como esta dinâmica interfere no seu bem-estar.

NERI e LUCENA 2002 com propriedade conceituam: "o cuidador familiar ao prestar cuidados ao idoso frágil ou dependente atende a motivos culturais, familiares e pessoais em complexa interação" (p. 778). As autoras assinalam ainda que a literatura internacional há 30 anos investiga o fenômeno do bem-estar do cuidador familiar, onde se constata que o cuidar acarreta prejuízos físicos, sociais e emocionais para o cuidador.

Em nosso estudo obtivemos diferentes representações dos cuidadores familiares no que se refere aos sentimentos quanto ao cuidado dispensado aos idosos. As representações foram: de retribuição, de dedicação, de amor, de despojamento, de sofrimento, de devoção, de possessão, de respeito, de desgaste e de sobrecarga, entre outros. Estes cuidadores cuidavam de seus idosos com respeito e dignidade, embora sentiam-se muitas vezes desencorajados pelo desgaste e pelas dificuldades que cotidianamente tinham de enfrentar no seu trabalho, sem ajuda e respaldo, solitários e desprovidos de toda atenção (ROSSETTO MAZZA, 2002).

Consoante NERI e LUCENA 2002, foi desenvolvida pesquisa em 2001 por Yuaso, com cuidadores familiares no domicílio onde os profissionais prestavam 
atendimento aos idosos. O resultado foi uma melhora do seu conhecimento e de suas habilidades e atitudes, interferindo na qualidade de vida de ambos.

Nos discursos obtidos com cuidadores familiares, (ROSSETTO MAZZA 2002) também demonstrou que há uma necessidade premente de conhecimentos e de capacidade de adquirir habilidades para o cuidado. Para eles, "saber cuidar é contar com o suporte e respaldo médico; é ter conhecimento técnico para o cuidado; é o resultado da obtenção de informação, buscar ajuda e ter paciência”(p. 69).

Cuidar e ser cuidado, especialmente em situação de fragilidade e por muitas vezes de dependência, é uma condição estressante para ambos os atores desta dinâmica relacional. "O cuidado é um processo interacional e evolutivo" (NERI e LUCENA, p.782), é uma construção e reconstrução cotidiana dos afetos, do carinho, do vencer barreiras e fantasmas do passado. É estar todos os dias com o idoso, “apesar de". 


\section{JUSTIFICATIVA}

Este trabalho é uma continuação da investigação iniciada no nosso trabalho de mestrado, onde o foco da atenção foi dada ao cuidador familiar, que é a figura central de atenção ao idoso no domicílio.

Diferentes representações sociais emergiram dos discursos dos cuidadores, e pudemos verificar que a busca do equilíbrio desta relação é a meta que muitos almejam atingir.

Pudemos comprovar também que o cuidado é uma prática na maioria das vezes muito desgastante e penosa, mas muitas vezes gratificante.

O que se pretendeu investigar neste estudo foi como se estabelecem as relações de cuidado nesta díade (cuidador familiar - idoso), desviando o olhar do cuidador familiar e focalizando este olhar no idoso, podendo, com isto, estabelecer a contrapartida para o entendimento desta dinâmica.

Ao focalizar o idoso pudemos fazer alguns questionamentos: Essa situação de cuidado dentro da família que gera stress, desgaste, exige abnegação por parte de quem presta o cuidado, será que é vista da mesma forma pelo idoso? Será que o idoso, na sua condição de fragilidade, aproveita-se disto escravizando o cuidador familiar, obrigandoo a prestar o cuidado sem considerar suas limitações, fragilidades e desconhecimento para o cuidado como alguns parecem acreditar? Ou será que pelo medo da velhice e da consciência de sua finitude sentem necessidade de atenção, agarrando-se ao cuidador como último refúgio?

Outros questionamentos poderão ser feitos baseados em uma das representações encontradas nos discursos do nosso trabalho, a qual foi que os cuidadores prestavam os cuidados como forma de retribuição do que tinham recebido quando crianças. Será de fato esta a atitude das pessoas idosas diante dos cuidadores familiares? Ou será que estes idosos se sentem merecedores deste cuidado?

O Brasil, pelas suas características culturais e pela condição socioeconômica bastante vulnerável da grande maioria da população, tem na família a grande cuidadora 
de seus idosos. É na família que os cuidados aos idosos acontecem quando eles se tornam vulneráveis e/ou dependentes.

Os potenciais cuidadores familiares estão diminuindo pela inserção da mulher no mercado de trabalho, pela mudança da estrutura familiar, pela diminuição da fecundidade, entre outros motivos exaustivamente apontados pelos estudiosos.

Os investimentos nas áreas sociais de amparo informal às famílias, inexistentes no Brasil, são medidas que não fazem parte da pauta dos projetos governamentais, reforçando ainda mais a responsabilidade exclusiva da família no cuidado ao idoso.

Seria ingênuo supor que estes cuidados são sempre ideais e que os idosos são assistidos sem ônus para os cuidadores familiares. O fato é que eles estão em seus lares por diferentes razões: por falta de opção da família, por necessidades financeiras dos filhos, que muitas vezes estão desempregados, o que torna a aposentadoria dos idosos uma contribuição fundamental para a manutenção da família; e também, muitas vezes, pela posição de respeito que o idoso mantém com seus familiares. Inúmeras são as razões para que esta díade se encontre em cena.

No cotidiano de nosso trabalho profissional, tendo sistematicamente contato com esses idosos e cuidadores familiares, presenciamos a tensão dessa relação de cuidados. Ao trabalhar com o idoso, a necessidade de que os serviços tanto de saúde como sociais têm do respaldo familiar é tanta, que sem ele a prestação do cuidado profissional fica prejudicada e difícil de ser realizada.

Isto é fato, porquanto as instituições que prestam atendimento aos idosos, nos hospitais ou nos serviços de atenção básica, exigem a presença do cuidador como condição primordial para o atendimento.

Sendo o idoso objeto do cuidado e figura central das políticas voltadas para este segmento é essencial conhecer as relações interfamiliares entre as gerações, ouvir o idoso, tentar compreender o que o cuidador familiar representa para ele e começar a entender esse universo das relações humanas tão cheias de nuances e de surpresas. 
É um desafio, como diz DEBERT 1999 "a dificuldade central dos trabalhos que procuram avaliar o bem-estar na velhice em termos de relações, entre as gerações, na família, está na ausência de medidores eficazes e definitivos" (p.87).

Podemos citar também outra recomendação de autores cubanos, que sugerem: "é necessário levar a cabo estudos analíticos que permitam estabelecer que fatores influenciam na tendência ao aparecimento de relações familiares inadequadas" (GONZÁLEZ, et al., 2001 p. 422). 


\section{OBJETIVOS}

1. Identificar o significado para a pessoa idosa com dependência para uma ou mais incapacidades funcionais, sobre o cuidado a ela prestado pelo seu cuidador familiar.

2. Identificar as representações sociais da pessoa idosa com dependência, referente a seu cuidador familiar. 


\section{MÉTODO}

\subsection{DEFINIÇÕES}

Na acepção de MINAYO, 2002 "metodologia é o caminho do pensamento e a prática exercida na abordagem da realidade ...é a articulação entre os conteúdos, pensamentos e existência ...A metodologia inclui as concepções teóricas de abordagem, o conjunto de técnicas que possibilitam a construção da realidade e o sopro divino do potencial criativo do investigador" (p. 16).

A metodologia utilizada nesta pesquisa foi a Qualitativa que, segundo MAZZOTTI-ALVES et.al. (1999) apud Patton 1986 “a principal característica das pesquisas qualitativas é o fato de que estas seguem a tradição compreensiva ou interpretativa(...)estas pesquisas partem do pressuposto de que as pessoas agem em função de suas crenças, percepções, sentidos e valores e que seu comportamento tem sempre um sentido, um significado que não se dá a conhecer de modo imediato, precisando ser desvelado" (p. 131).

Para MINAYO, 2002 "a pesquisa qualitativa responde a questões muito particulares. Ela se preocupa, nas Ciências Sociais, com um nível de realidade que não pode ser quantificado... ela trabalha com o universo de significados, motivações, aspirações, crenças, valores e atitudes o que corresponde a um espaço mais profundo das relações, dos processos e dos fenômenos que não podem ser reduzidos à operacionalização de variáveis... ela aprofunda-se no mundo dos significados das ações e relações humanas, um lado não perceptível e não captável em equações, médias e estatísticas" (p. 22).

A teoria utilizada para desvendar a representação dos idosos sobre seus cuidadores familiares foi a da Representação Social de Moscovici. Para efeito didático, definiremos o conceito de Teoria segundo MINAYO 2002: "é o conhecimento anterior, construído por outros estudiosos e que lançam luz sobre a questão de nossa pesquisa... ela é construída para explicar ou compreender um fenômeno, um processo ou um 
conjunto de processos e fenômenos.... ela tem sempre um caráter abstrato" (p. 18). Através de seu conhecimento no processo de investigação podemos formar um sistema de proposições que nos orientam a obter os dados, a análise, expandindo os conceitos e veiculando seu sentido. (idem).

Para a obtenção dos dados da pesquisa foi utilizada a Técnica do Discurso do Sujeito Coletivo (LEFÈVRE e LEFÈVRE, 2002).

\subsection{TEORIA DA REPRESENTAÇÃO SOCIAL}

O conceito de Representação Social tem sido usado em muitas pesquisas de diversas áreas como da saúde, da educação, da didática, do meio ambiente, apresentando inclusive propostas teóricas diversificadas (ARRUDA, 2002, p. 128).

Moscovici foi o idealizador desta teoria, onde retoma o conceito de representação coletiva de Durkheim, amparado no interesse de um pequeno grupo de psicólogos sociais que queriam reviver este conceito. Este conceito "durkheiniano" "designava prioritariamente uma ampla classe de formas mentais (ciência, religiões, mitos, espaço, tempo), de opiniões e de saberes sem distinção, mas não estando suas características cognitivas especificadas... ela era partilhada e reproduzida de modo coletivo" (MOSCOVICI, 2001, p. 47). A abrangência deste conceito tornava a teoria pouco operacional. Para Durkhheim havia uma oposição do individual e do coletivo.

A obra de Moscovici que inaugurou a matriz da teoria foi La Psychanalyse, son image, son public, lançada na França em 1961, e causou polêmica no meio acadêmico. O impulso desta teoria se deu apenas nos anos 80, tendo um vácuo de mais de 20 anos.

A teoria proposta por Moscovici sofreu influência dos estudos de alguns pesquisadores da sociologia, antropologia, psicologia clínica, psicologia social.

Compuseram a teoria os conceitos de Levy-Bruhl que defendia o abandono do antagonismo entre o individual e o coletivo, focando luz nas relações entre a sociedade e 
suas representações. Levy-Bruhl descobriu a coerência dos sentimentos e dos raciocínios, os movimentos da vida mental coletiva. (MOSCOVICI, 2001, p. 51).

ARRUDA 2002 reitera: "Levy-Bruhl, por meio de estudos sobre o pensamento místico encontrado em povos distantes, aponta outras formas de lógica para pensar o mundo, baseadas em princípios diversos do pensamento ocidental, como o princípio de participação”. (p. 136). Ele dá outra feição ao conceito de representação coletiva.

Piaget, psicólogo suíço, teve muita influência ao contribuir com a descrição a respeito do desenvolvimento do pensamento infantil, a forma com se estruturava e se configurava (ARRUDA, 2002). "Lega-nos uma análise que estabelece a especificidade das representações em termos psíquicos(...) ele se defrontou com o difícil problema da natureza psíquica das representações.” Piaget desvela o modelo social e descobre os mecanismos psíquicos do fenômeno social. (MOSCOVICI, 2002, p. 55).

Outro teórico que ajudou a compor a teoria foi Freud em seus primeiros estudos sobre a paralisia histérica e o tratamento psíquico... onde destaca a força das representações. Com as teorias sexuais das crianças, mostra como elas elaboram e internalizam suas próprias teorias sobre questões fundamentais para a humanidade, teorias que carregam as marcas sociais da sua origem (ARRUDA, 2002, p. 136). Para Moscovici o estudo de Freud contribuiu na medida em que este trabalho de interiorização marca o caráter da pessoa mostrando o processo de passagem das representações do espaço coletivo para o individual; do consciente para o inconsciente. (MOSCOVICI, 2002).

A proposta de Moscovici com a Teoria da Representação era operacionalizar o conceito para poder trabalhar com o pensamento social em sua dinâmica e diversidade. Com esta sistematização reabilitou o senso comum, o saber popular, o conhecimento do cotidiano, questionando a racionalidade científica tão presente na época. Sua obra pôs em cheque os conceitos das ciências psicológicas, cujas premissas se baseavam "na fronteira entre razão e senso comum, razão e emoção, sujeito e objeto". Sua proposta era que a realidade é socialmente construída e o saber é uma construção do sujeito, mas não desligada da sua inscrição social. 
ABRIC 2000 preceitua que "o abandono da dicotomia sujeito-objeto confere um novo estatuto que se convencionou chamar de realidade objetiva, isto é, toda realidade é representada, quer dizer, reapropriada pelo indivíduo ou pelo grupo, reconstruída no seu sistema cognitivo, integrada no seu sistema de valores, dependente de sua história e do contexto social e ideológico que o cerca" (p. 27).

Com isto, Moscovici propõe "uma psicossociologia do conhecimento, com forte apoio sociológico sem desprezar os processos subjetivos e cognitivos" (ARRUDA, 2002, p. 131).

Denise Jodelet foi a pesquisadora que aprofundou e difundiu a teoria das representações sociais, sendo sua embaixadora no mundo.

Para ela, "as representações sociais são importantes em nossas vidas porque nos guiam no modo de nomear e definir conjuntamente os diferentes aspectos da realidade diária, no modo de interpretar esses aspectos, de tomar decisões e eventualmente nos posicionarmos frente a eles de forma defensiva". Elas são fenômenos complexos sempre ativados e em ação na vida social. Os diversos elementos que permeiam as representações (crenças, valores, atitudes, opiniões, imagens, ideológicos, cognitivos etc.) são organizados sempre sob a aparência de um saber que diz algo sobre o estado da realidade (JODELET, 2001, pp. 17, 21).

ARRUDA 2002 considera que "Jodelet lembra que a representação social deve ser estudada articulando elementos afetivos, mentais e sociais, e integrando, ao lado da cognição, da linguagem e da comunicação, as relações sociais que afetam as representações e a realidade material, social e ideal sobre a qual elas vão intervir" (p.138).

A teoria da representação social é alvo de muitas críticas, pois "sua conceituação é fluida, com múltiplos enunciados e propõe metodologias variadas e pouco amarradas(...) Perceber uma representação social é fácil, mas defini-la, nem tanto".(idem, p.138). Sá também confirma esta dificuldade, alertando que defini-la não é tarefa fácil dada sua composição polimorfa (DUARTE, 2007, p. 26). 
WAGNER 2000 reitera que o conceito de Representação Social "possui múltiplas facetas". Para alguns pesquisadores é entendido como um processo social de comunicação e discurso; para outros, como atributos individuais, como estruturas de conhecimento individualmente acessíveis embora compartilhadas... Este ponto dual do conceito torna-o versátil, dando margem a várias interpretações e práticas... (p. 3).

CARDOSO e GOMES 2000 também expõem o seu caráter controverso e diversificado, mas atestam sua importância quando verificam seu princípio norteador presente nas diversas pesquisas na área das ciências sociais.

\subsection{1 - Conceitos de Representação Social para Alguns Pesquisadores}

DUVEEN (2003) na Introdução da publicação de Moscovici 2003 exprime que as representações sociais emergem a partir de pontos duradouros de conflito (p. 16) ...elas são sempre um produto da interação e comunicação, tomam forma e configuração específica como conseqüência do equilíbrio do meio social (p. 21).

Moscovici, em 1976, definiu-as como "um sistema de valores, idéias e práticas com uma dupla função: primeiro, estabelecer uma ordem que possibilitará às pessoas orientar-se em seu mundo material e social e controlá-lo; segundo lugar, possibilitar que a comunicação seja possível entre os membros de uma comunidade, fornecendo-lhes códigos para nomear e classificar, sem ambigüidades, os vários aspectos de seu mundo e sua história individual e social" (DUVEEN, 2003, p. 21).

Pelo fato de a teoria gerar diversos questionamentos, Arruda informa que inúmeros pesquisadores propuseram sua própria definição de acordo com seu foco de interesse e sua posição teórica.

JODELET 2001 caracteriza a Representação Social como "uma forma de conhecimento, socialmente elaborada e partilhada, com um objetivo prático, e que contribui para a construção de uma realidade comum a um conjunto social. Igualmente designada como "saber do senso comum," "saber ingênuo," "natural," esta forma de 
conhecimento é diferenciada, entre outras, do conhecimento científico. Entretanto, é tida como um objeto de estudo tão legítimo, devido à sua importância na vida social e à elucidação possibilitadora dos processos cognitivos e das interações sociais” (p. 22).

ABRIC 2000 define-a "como uma visão funcional do mundo, que, por sua vez, permite ao indivíduo ou ao grupo, dar um sentido às condutas e compreender a realidade através de seu próprio sistema de referências; permitindo assim ao indivíduo de se adaptar e de encontrar um lugar nesta realidade... ela funciona como um sistema de interpretação da realidade que rege as relações dos indivíduos com o seu meio físico e social, ela vai determinar seus comportamentos e suas práticas" (p. 28).

Na lição de WAGNER 2000 "é um conteúdo mental estruturado, isto é, cognitivo, avaliativo, afetivo e simbólico sobre o fenômeno social relevante que toma a forma de imagens e metáforas e que é conscientemente compartilhado com outros membros do grupo social" (p. 3).

MOREIRA e OLIVEIRA, 2000 entendem-na “como idéias, imagens, concepções e visões de mundo que os atores sociais constroem sobre a realidade as quais estão vinculadas às práticas sociais, ou seja, cada grupo social elabora representações de acordo com a sua posição no conjunto da sociedade, representações essas que emergem de seus interesses específicos e da própria dinâmica da vida cotidiana” (p. xi).

ALMEIDA e CUNHA 2003 também a nomeiam como teoria do senso comum ou teoria popular, correspondendo aos significados psicossociais: "Esses significados são compreendidos como constituídos e constitutivos da realidade social sendo, portanto, explicativos e prescritivos da realidade social." Ela é articulada às teorias científicas que submetem esses conhecimentos a um processo de ressignificação, pois são negociados elaborados no cerne das teorias populares. (p. 147).

ARRUDA (2002) define-a como "uma espécie de 'fotossíntese cognitiva': metaboliza a luz que o mundo joga sobre nós sob a forma de novidades que iluminam, transformando-a em energia. Ela incorpora-se ao nosso pensar/perceber este mundo e a devolvemos a ele como entendimento mas também como juízos, definições, classificações. Como na planta, esta energia nos colore, nos singulariza diante dos 
demais... ela significa intensas trocas e mecanismos complexos que, constituindo eles mesmos um ciclo, contribuem para o ciclo da renovação da vida ...é através dela que residem nossas chances de transformar ou, quando menos, de entender as dificuldades para a transformação do pensamento social”' (p. 138).

Para finalizar, transcreveremos o que Jodelet diz: "O papel das representações no devir social se anuncia como um objeto de estudo estimulante no futuro ...o seu modelo impulsiona a diversidade e a invenção, traz o desafio da complexidade..." (JODELET, 2001, pp. 39 e 41).

\subsection{TÉCNICA DE ANÁlISE DOS DADOS - DISCURSO DO SUJEITO COLETIVO - DSC}

A técnica do Discurso do Sujeito Coletivo é uma, dentre muitas, para desvendar as representações sociais de uma determinada população.

Para os autores da técnica, o Discurso do Sujeito Coletivo - DSC é uma metodologia de preparo ou processamento da matéria-prima dos depoimentos obtidos das coletividades estudadas.

É “um conjunto harmônico de processos e procedimentos destinados, a partir de depoimentos colhidos em pesquisas sociais de opinião, a conformar, descritivamente, a opinião de uma dada coletividade como produto qualiquantitativo, isto é, como um painel de depoimentos discursivos, ou seja, qualidades provenientes de quantitativos de indivíduos socialmente situados” (LEFÈVRE e LEFÈVRE, 2005, p. 7).

O desenvolvimento desta técnica teve origem na década de 1990, fruto de uma pesquisa desenvolvida junto aos servidores públicos do Estado de São Paulo, cujo objetivo era conhecer sua opinião sobre o Programa de Gerenciamento Integrado idealizado na gestão do secretário de Saúde da época.

O trabalho de análise dos discursos propiciou a criação do DSC, com o seu aperfeiçoamento até hoje. 
Esses autores declararam que "a técnica do DSC constitui-se em um recurso metodológico que permite a realização de pesquisas de resgate das opiniões coletivas(...) Nas pesquisas com o DSC o pensamento é coletado por entrevistas individuais com questões abertas, o que faz com que o pensamento, como comportamento discursivo e fato social individualmente internalizado, possa se expressar." (2005, p.21).

Sua definição, de acordo com seus idealizadores, "é uma forma não matemática nem metalingüística de representar (e de produzir), de modo rigoroso, o pensamento de uma coletividade, o que se faz mediante uma série de operações sobre os depoimentos, que culmina em discursos-sínteses que reúnem respostas de diferentes indivíduos, com conteúdos discursivos de sentido semelhantes". Ele é uma inovação em pesquisas empíricas de opinião porque os seus resultados não são sob a forma de categorias, mas na forma de discursos que emitem o pensamento das coletividades (LEFÈVRE e LEFÈVRE, 2005, p. 25).

Com o DSC é possível resgatar as representações sociais deixando-se, objetivamente, a afetividade delas, quando for o caso, vir à tona (idem, p. 46).

O DSC pode ser obtido de depoimentos, artigos de jornais, materiais de revistas semanais, cartas, papers, etc....” “(...) o sujeito coletivo se expressa através de um discurso emitido no que se poderia chamar de primeira pessoa (coletiva) do singular. Trata-se de um eu sintático, que, ao mesmo tempo que sinaliza a presença de um sujeito individual do discurso, expressa uma referência coletiva na medida em que este eu fala pela ou em nome da coletividade”. “(...) O eu do DSC é uma tentativa de resgate desse eu social ou coletivo, ou seja, ele é um recurso criado para emergir o inconsciente social que fala no indivíduo" (idem, 2005, p. 35).

É usada a primeira pessoa do singular porque assim permite sinalizar que a sociedade se impõe ao indivíduo pela internalização inconsciente de seus discursos (idem).

Portanto, "o DSC não é uma soma aritmética, mas uma agregação discursiva que não reúne iguais, mas pedaços de diferentes discursos individuais que pelo que se julga ser sua intercompatibilidade permitem, como se fossem ingredientes agregáveis, compor 
um único bolo discursivo(...). Seu conteúdo é composto por aquilo que um dado sujeito individual falou, e também por aquilo que poderia ter falado e que seu companheiro de coletividade atualizou por ele, já que o pressuposto sociológico de base é que o DSC é a expressão simbólica do campo a que ambos pertencem e da posição que ocupam dentro deste campo, ou de uma cultura organizacional" (idem, 2003 p. 16).

Para a sua construção implica a utilização de quatro figuras metodológicas: a ancoragem, a idéia central, as expressões-chave e o discurso do sujeito coletivo.

\subsection{1 - Figuras Metodológicas}

Expressões-chave são transcrições literais de partes dos depoimentos que autorizam o resgate do essencial do conteúdo dos discursos. Elas são uma espécie de prova discursiva empírica da "verdade" (destaque dos autores) das idéias centrais e das ancoragens.

Idéia central diz respeito à(s) afirmação(ões) que permite(m) traduzir o essencial do conteúdo discursivo explicitado pelos sujeitos nos discursos. É uma tarefa difícil para o pesquisador porque, como dizem os autores, "trata de uma operação basicamente intelectual ou cognitiva". Ela deve ser concisa, respeitar o conteúdo e o sentido da resposta emitida pelo sujeito, e identificar que idéias ou idéia ela expressa.

Ancoragem de um discurso é quando podemos encontrar nele traços lingüísticos explícitos de teorias, hipóteses, conceitos, ideologias existentes na sociedade e na cultura, e que estão internalizadas nos indivíduos.

Identificamos uma ancoragem quando "o depoente usa uma afirmação genérica para enquadrar, justificar ou explicar uma situação particular”. Ela deve ser redigida no positivo (idem, 2005, p. 88).

Discurso do Sujeito Coletivo é a reconstrução, com pedaços de discursos individuais, em que se busca resgatar o discurso como signo de conhecimentos dos próprios discursos. 
É uma estratégia metodológica com vistas a tornar mais claros uma dada representação social e o conjunto das representações que conforma um dado imaginário. Através dele podemos compreender de uma forma mais viva e direta o modo como os indivíduos reais e concretos pensam.

O discurso do sujeito coletivo é como "se fosse uma pessoa real falando, tendo essa fala o pensamento coletivo como conteúdo" (idem, 2005, p. 91). Não será possível alterar o sentido original das falas.

\subsection{2 - Atributos Quantitativos do Discurso do Sujeito Coletivo}

Intensidade ou Força: trata-se do número de indivíduos que contribuíram com suas expressões-chave para a construção das idéias centrais ou ancoragens semelhantes.

Amplitude: medida da extensão do DSC no campo ou universo pesquisado.

\section{4.- PROCEDIMENTOS METODOLÓGICOS}

\subsubsection{População do Estudo}

A população foi constituída de 31 idosos com 65 anos e mais de idade e que apresentavam alguma forma de dependência física, ou seja, déficit de mobilidade e dificuldade na execução das Atividades de Vida Diária (AVDs) e Atividades Instrumentais de Vida Diária (AIVDs), e que possuíam um cuidador familiar responsável pelo seu cuidado. Apenas um idoso recusou-se a participar da pesquisa.

Os critérios de exclusão foram: idosos portadores de deficiências cognitivas; por deficiências da fala; por acometimento de AVC com seqüelas que impediam seu depoimento; idosos que não possuíam um cuidador familiar; idosos que moravam sós ou com um cuidador profissional. 
Os idosos eram matriculados e atendidos no Centro de Saúde Escola Geraldo de Paula Souza (CSEGPS), pertencente à Faculdade de Saúde Pública da USP. Estes foram identificados através de:

1. consultas aos prontuários do CSEGPS;

2. contato informal com o cuidador familiar e com o idoso ao longo do processo de atendimento na unidade;

3. encaminhamento dos demais profissionais do serviço.

Os instrumentos utilizados foram:

1 Roteiro de Entrevista (Anexo 2);

2. Ficha de Identificação do Idoso (Anexo 4);

3. Instrumento de Avaliação da Capacidade Funcional do Idoso - Escala de Akhtar, (Anexo 5);

\section{Teste O’Clock (Anexo 3);}

5. Termo de Consentimento Livre e Esclarecido (Anexo 1).

A composição da amostra foi intencional, baseada nos pressupostos metodológicos de LEFÈVRE et al. 2000 quando determinam: "a seleção da amostra em pesquisas deste tipo deve considerar a quantidade, a variabilidade e qualidade dos sujeitos a serem entrevistados, em termos das possibilidades deles fornecerem dados ricos, interessantes e suficientes para compor e reconstruir o horizonte de pensamento... a quantidade não é uma variável crítica, sendo a variabilidade muito mais crítica, considerando a necessidade de recuperação das várias possibilidades presentes num dado campo social e ideológico...” (p. 35). 


\subsection{2 - Local do Estudo}

O Centro de Saúde Escola Geraldo de Paula Souza pertence à Faculdade de Saúde Pública da Universidade de São Paulo e possui uma área de abrangência de aproximadamente 100 mil habitantes, da região da Subprefeitura de Pinheiros.

Este Centro de Saúde Escola tem como função o ensino e pesquisa em Saúde Pública e serve como campo de estágio para a Faculdade de Nutrição da USP e demais faculdades, tanto da USP com de faculdades particulares. Tem também a função de prestação de serviço de saúde para a sua área de abrangência no atendimento em níveis primário e secundário de atenção à saúde desta população, composta por crianças, adolescentes, adultos e idosos.

Com este caráter de ensino e pesquisa em 2004, o CSE, através da parceria com a Faculdade de Medicina da USP e da Subprefeitura de Pinheiros, criou a Unidade de Referência de Saúde do Idoso (URSI) com duplo objetivo: servir de campo de formação profissional em geriatria e gerontologia, e o atendimento de saúde em nível ambulatorial de idosos mais fragilizados e com necessidades de saúde da região de Pinheiros.

\subsection{3. - Coleta de Dados}

\subsubsection{Pré-teste, elaboração do instrumento definitivo}

A aplicação do pré-teste foi em novembro de 2004 com quatro idosos que eram familiares de usuários do Centro de Saúde, com o objetivo de subsidiar a construção do Instrumento Definitivo da Coleta de Dados da Pesquisa (Anexo 2). As entrevistas do pré-teste foram realizadas e gravadas no domicílio dos idosos e posteriormente transcritas e analisadas para compor o instrumento.

Este instrumento foi modificado e reaplicado em um novo pré-teste, procurando com isto ajustá-lo para atingir os objetivos propostos pelo estudo. 


\subsubsection{Instrumento Definitivo}

A versão definitiva do instrumento foi um roteiro de entrevista composto de dados pessoais do idoso e do cuidador, e por questões abertas que permitiram aos entrevistados manifestar livremente o que representava este cuidador familiar para o idoso e desvendar o universo de cuidados entre esta díade (idoso - cuidador familiar).

O instrumental utilizado para a coleta de dados foi "Entrevista Aberta SemiEstruturada e Individual” que, como destaca SIMIONI (1997), “...são aquelas em que o informante fala livremente sobre o tema proposto, limitado, contudo, por um roteiro de questões a serem pontuadas no momento da entrevista”.

As questões elaboradas foram as seguintes:

questão 1: "O/A $\operatorname{Sr}(\mathrm{a})$. é cuidado(a) pelo(a) .................. Ele(a) é um bom cuidador(a)? Fale-me um pouquinho sobre isso", tentando perceber que sentimentos e emoções estão envolvidos no cuidado dispensado pelo cuidador familiar;

questão 2: "Como seria se o/a $\mathrm{Sr}(\mathrm{a})$. não estivesse sendo cuidado pelo(a).............?", para identificar em que medida este cuidador familiar é importante como cuidador;

questão 3: $\mathrm{O} / \mathrm{A} \operatorname{Sr}(\mathrm{a})$. acha que precisaria de alguém mais para cuidar do $\operatorname{Sr}(\mathrm{a}) . ?$ ?" para reconhecer o julgamento que o idoso faz do cuidado que lhe é dispensado e do cuidador familiar.

\subsubsection{Realização das Entrevistas}

As entrevistas foram realizadas no período de 31 de maio de 2005 a 17 de janeiro de 2006. Foram realizadas no ambiente domiciliar pelo fato de ser mais fácil para o idoso, e para o seu cuidador, pois o idoso possuía fragilidades e dependências que dificultariam a sua locomoção. No domicílio era que o cuidado se concretizava e era o local favorável para que o idoso pudesse falar sobre o assunto com mais liberdade, 
evitando assim um viés indesejado. Apenas dois idosos preferiram fazer a entrevista no CSE, e foi respeitada essa vontade.

Foi solicitado, sempre que possível, a permanência do cuidador no domicílio no momento da entrevista, sem contudo participar dela para evitar constrangimentos por parte do idoso, pelo fato de ser o cuidador o sujeito principal mencionado na entrevista. Em duas entrevistas isto não foi possível.

Após preencher os dados de identificação do idoso; o instrumento da escala de avaliação funcional; a assinatura do termo de consentimento e a execução do teste o`clock, os depoimentos foram gravados em fita magnética após novamente ser consultado o seu consentimento.

Todas as entrevistas foram realizadas pela pesquisadora e tiveram a duração média de 10 minutos, embora a permanência do pesquisador no domicílio tenha sido de aproximadamente 2 horas em média.

A realização de todas as entrevistas transcorreu de forma harmônica e acolhedora, com a participação tranqüila dos idosos, o que surpreendeu a pesquisadora. Em alguns momentos foi necessário quebrar o constrangimento da pesquisadora, principalmente nas primeiras entrevistas, por estar abordando determinados assuntos e superar estas limitações a fim de poder prosseguir com a investigação.

As entrevistas foram analisadas utilizando o software Quali-Quanty desenvolvido por LEFÈVRE e LEFÈVRE (2003), FSP-USP.

\subsubsection{4 - Organização e análise dos dados}

Conforme exposto, a técnica utilizada para o tratamento dos dados obtidos nas entrevistas semi-estruturadas com os idosos foi a do Discurso do Sujeito Coletivo DSC- em que as quatro figuras metodológicas foram contempladas.

O modus operandi da técnica pode ser consultado na publicação de 2005 dos autores, onde o leitor tem condições de compreender passo a passo o uso do Qualiquantisoft. 
Algumas observações quanto ao modo utilizado pela pesquisadora para confeccionar os discursos se fazem necessárias.

O software desenvolvido por LEFÈVRE e LEFÈVRE, favoreceu a análise dos dados na medida em que foram organizados e listados os depoimentos, facilitando o trabalho de identificação das idéias centrais adequadas às expressões-chaves e ancoragens encontradas nos depoimentos, sendo os precursores dos Discursos do Sujeito Coletivo.

Ao agruparmos os depoimentos com o mesmo sentido e o mesmo conteúdo, "a reconstrução com pedaços de discursos individuais" se deu de maneira tranqüila, de modo que foi possível identificar as diferentes representações dos idosos.

O fato de termos uma amostra composta de sujeitos idosos e do objeto a que se referiam, no caso os cuidadores familiares, era composta de diferentes tipos (filha, esposa, esposo, filho, nora, genro) a escolha do "eu coletivo" ou "sujeito" que daria voz ao discurso e muitas vezes foi por aquele que mostraria o conteúdo de uma forma mais explícita e esclarecedora da representação.

Ao identificar uma representação onde vários sujeitos idosos compartilhavam de uma mesma idéia, existia sempre um depoimento que norteava esta representação, facilitando, portanto, a construção dos DSCs a partir da "reconstrução com pedaços de discursos individuais".

Para finalizar, gostaríamos de mencionar que o Discurso do Sujeito Coletivo é uma técnica que vem se estabelecendo em pesquisas sociais com o objetivo de trazer à tona as representações sociais de uma coletividade. Como bem esclarecem os autores, "O DSC se coloca como uma técnica que se assume explicitamente como uma proposta de reconstrução descritiva de opiniões ou de representações sociais, e que, ademais, abre à crítica dos pesquisadores e dos leitores todos os procedimentos utilizados, desde o início da investigação até seu final, para a obtenção da descrição das representações" (2005, p. 38). 


\section{RESULTADOS}

\section{1 CARACTERIZAÇÃO DA REGIÃO}

Os idosos, sujeitos da pesquisa, são residentes da área de abrangência do Centro de Saúde Escola Geraldo de Paula Souza da Faculdade de Saúde Pública/USP, situado na região oeste de São Paulo e pertencente à Subprefeitura de Pinheiros.

A região de Pinheiros possui quatro distritos administrativos: Alto de Pinheiros, Itaim Bibi, Jardim Paulista e Pinheiros.

Compreende uma área de $31,7 \mathrm{~km}^{2}$, com uma população total de 272.574 habitantes e uma densidade demográfica $\left(\mathrm{hab} / \mathrm{km}^{2}\right)$ de 8.598,5.

A taxa de urbanização é total, ou seja, de $100 \%$. A taxa de crescimento no período de 1991-2000 foi negativa -2,41\%, e a população em idade ativa é de 197.682 (SEADE, 2004, Instituto Brasileiro de Geografia e Estatística - IBGE - Censos Demográficos 1991 e 2000; Lei Municipal 10.932, de 15 de janeiro de 1991).

A Figura 1 mostra o mapa do município de São Paulo, com destaque para a região de Pinheiros. 
Figura 1: Mapa do município de São Paulo, com destaque para a região oeste Pinheiros.

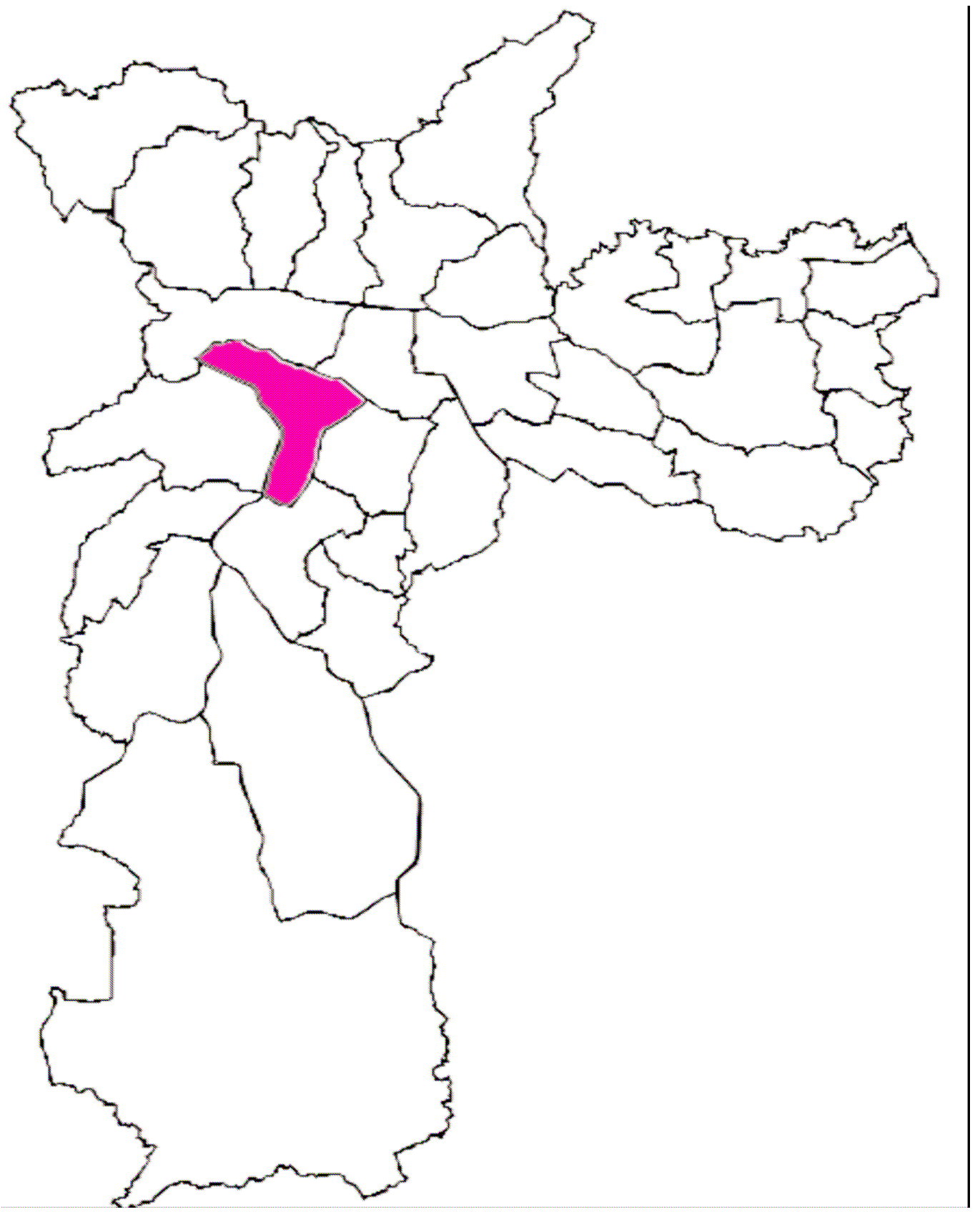

Extraído de: Seade, 2004 
A Figura 2 detalha a região nos seus quatro distritos administrativos. O Centro de Saúde onde foi realizada a pesquisa fica localizado entre os distritos de Pinheiros e Jardim Paulista. Os idosos, na sua totalidade, eram moradores desta área.

Figura 2 Distritos administrativos de Pinheiros, região oeste do município de São Paulo.

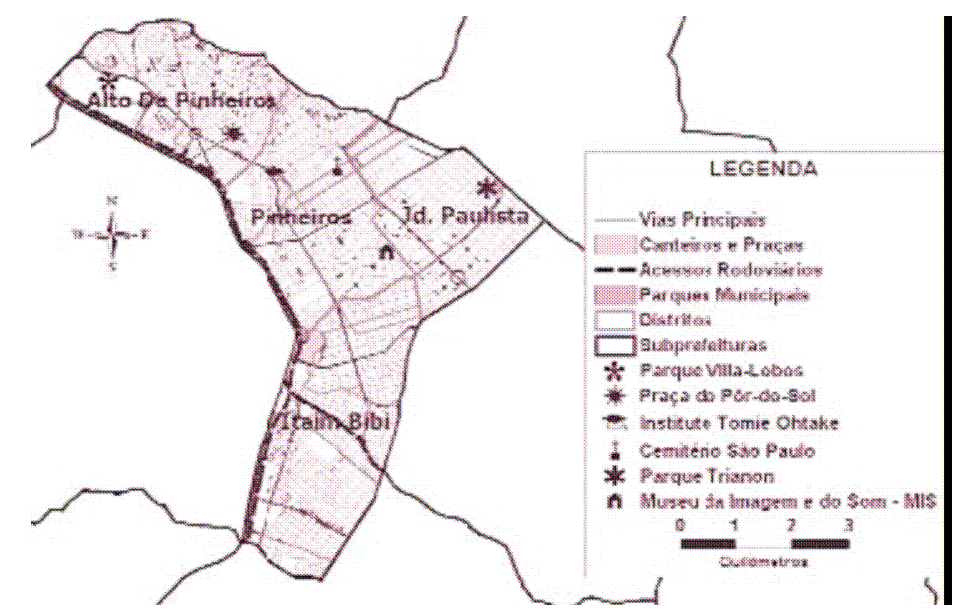

Extraído de: Seade, 2004 (Companhia de Processamento de Dados do Município de São Paulo (PRODAM), Geolog. 2.1.2, e Lei Municipal 10.932 de 15 de janeiro de 1991).

A Figura 3 mostra que a Atividade Econômica da região gira em torno de "Comércio e Serviços", correspondendo a 79,91\% da quantidade de empregos oferecidos. 
Figura 3 Empregos por tipo de atividade - região de Pinheiros, São Paulo.

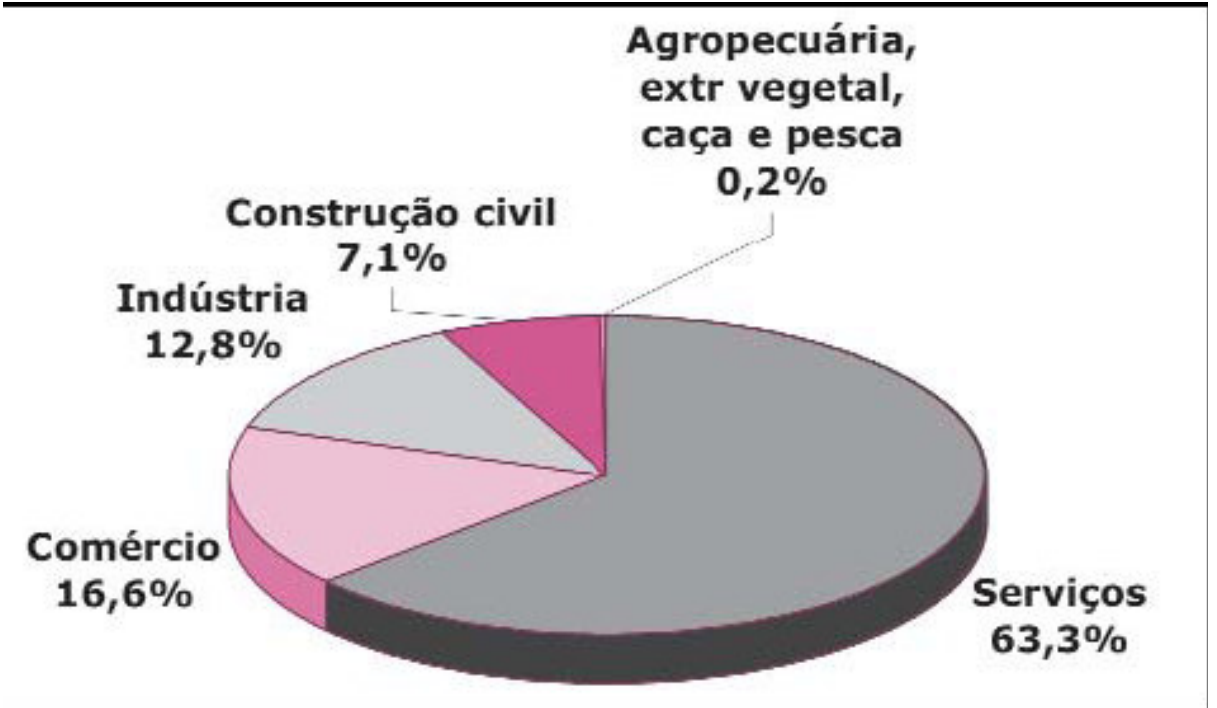

Extraído de: Seade, 2004.

Quanto aos Indicadores Educacionais a taxa de analfabetismo é de 0,94\%. Podemos observar na Tabela 1 que os chefes de família possuem em média 12,67 anos de estudo, índice bem acima da média do município de São Paulo, que é de 7,67\%.

Tabela 1 Indicadores Educacionais dos chefes de família da região de Pinheiros e do município de São Paulo.

\begin{tabular}{lcc}
\hline Tipo de Indicador & Pinheiros & MSP* \\
\hline $\begin{array}{l}\text { Com ensino } \\
\text { fundamental } \\
\text { completo (\%) }\end{array}$ & 79,40 & 49,69 \\
\hline $\begin{array}{l}\text { Com ensino médio } \\
\text { completo (\%) }\end{array}$ & 71,48 & 33,68 \\
\hline $\begin{array}{l}\text { Média de anos de } \\
\text { estudo }\end{array}$ & 12,67 & 7,67 \\
\hline
\end{tabular}

*Município de São Paulo.

Extraído de: Seade, 2004. 
Quanto ao item Desenvolvimento Social, a Assistência Social Municipal possui 19 grupos diferentes de equipamentos, conforme Tabela 2.

Tabela 2 Equipamentos municipais de Assistência Social da região de Pinheiros comparados aos equipamentos do município de São Paulo.

\begin{tabular}{ccccc}
\hline $\begin{array}{c}\text { Grupo de } \\
\text { equipamentos }\end{array}$ & $\begin{array}{l}\text { Número de } \\
\text { unidades } \\
\text { Pinheiros }\end{array}$ & $\begin{array}{l}\text { Número } \\
\text { de unidades } \\
\text { MSP* }\end{array}$ & $\begin{array}{l}\text { Capacidade de } \\
\text { atendimento } \\
\text { Pinheiros }\end{array}$ & $\begin{array}{l}\text { Capacidade de } \\
\text { atendimento } \\
\text { MSP* }\end{array}$ \\
\hline Acolhe & 6 & 92 & 460 & 10.503 \\
Convive & 13 & 625 & 1.510 & 80.083 \\
Defende & 0 & 17 & 0 & 2.430 \\
Provê & 0 & 49 & 0 & 31.206 \\
\hline Total & $\mathbf{1 9}$ & $\mathbf{7 8 3}$ & $\mathbf{1 . 9 7 0}$ & $\mathbf{1 2 4 . 2 2 2}$ \\
\hline
\end{tabular}

*Município de São Paulo

Extraído de: Seade 2004 (Secretaria Municipal de Assistência Social /PMSP, 2003)

Ao verificarmos a Tabela 2 notamos uma deficiência de equipamentos sociais na região, se comparada ao restante do município de São Paulo. Podemos levantar a hipótese de que a pequena participação da Assistência Social se dá pelo alto poder aquisitivo, o que pode ser constatado pelos indicadores socioeconômicos, mostrando que o rendimento do chefe de família é alto se comparado a média do município de São Paulo. Em Pinheiros o rendimento médio dos chefes de família é de R\$ 4.402,84. 
Tabela 3 Indicadores Socioeconômicos dos chefes de família da região de Pinheiros e do município de São Paulo.

\begin{tabular}{|c|c|c|}
\hline $\begin{array}{l}\text { Rendimento dos chefes de } \\
\text { Família }\end{array}$ & $\begin{array}{c}\% \\
\text { Pinheiros }\end{array}$ & $\begin{array}{c}\% \\
\text { MSP* }\end{array}$ \\
\hline Sem Rendimento & 4,34 & 10,43 \\
\hline Até 5 salários mínimos & 11,56 & 47,55 \\
\hline $\begin{array}{c}\text { Mais de } 5 \text { a } 20 \text { salários } \\
\text { mínimos }\end{array}$ & 39,45 & 32,58 \\
\hline $\begin{array}{l}\text { Mais que } 20 \text { salários } \\
\text { mínimos }\end{array}$ & 44,66 & 9,44 \\
\hline $\begin{array}{l}\text { Rendimento médio dos } \\
\text { chefes de família }(\mathrm{R} \$)\end{array}$ & $4.402,84$ & $1.325,43$ \\
\hline
\end{tabular}

Quanto às Informações Urbanas, a região tem aproximadamente $100 \%$ de cobertura de iluminação, rede de água, esgoto e coleta de lixo, sem apresentar áreas de risco para seus habitantes dos tipos setores de risco ou domicílios em áreas de risco. Possui uma população favelada de 552 habitantes, considerada pequena se comparada com outras regiões do município. Conta com uma boa cobertura de transporte, tanto de corredor de ônibus quanto de estações de metrô.

No quesito Equipamentos de Cultura e Esporte Pinheiros possui três bibliotecas, localizadas em: Alto de Pinheiros, Jardim Paulista e Itaim Bibi, e quatro clubes desportivos municipais, todos no Itaim Bibi.

Os Equipamentos de Saúde da região são compostos de quatro hospitais estaduais, três hospitais privados, três Unidades Básicas de Saúde (UBS) e dois Centros de Saúde Escola, e conta também com o Programa Saúde da Família.

As principais causas de morte encontradas foram: as doenças isquêmicas do coração, seguidas das doenças cerebrovasculares, doenças pulmonares e CA de pulmão (Figura 4). 
Segundo CAMARANO et al. 2004 as principais causas de morte entre os idosos brasileiros observadas em 2000 foram: $1^{a}$ doenças do aparelho circulatório, correspondendo a $35,5 \%$ para o sexo masculino e $38,2 \%$ para o sexo feminino; $2^{a}$ sintomas, sinais e achados anormais de exames clínicos e de laboratório não classificados em outra parte, com $16 \%$ para ambos os sexos; e $3^{a}$ neoplasias, doenças do aparelho respiratório e doenças endócrinas, nutricionais e metabólicas, correspondendo a 6,4\% do total de óbitos, e $4^{o}$ causas externas como: acidentes de transporte público, de trânsito, de quedas, de homicídios, afogamentos e envenenamentos. Podemos observar que as causas de morte brasileiras e particularmente na região de Pinheiros são parecidas com as dos países desenvolvidos (pp. 38, 43).

Figura 4 - Principais Causas de Morte na região de Pinheiros, São Paulo.

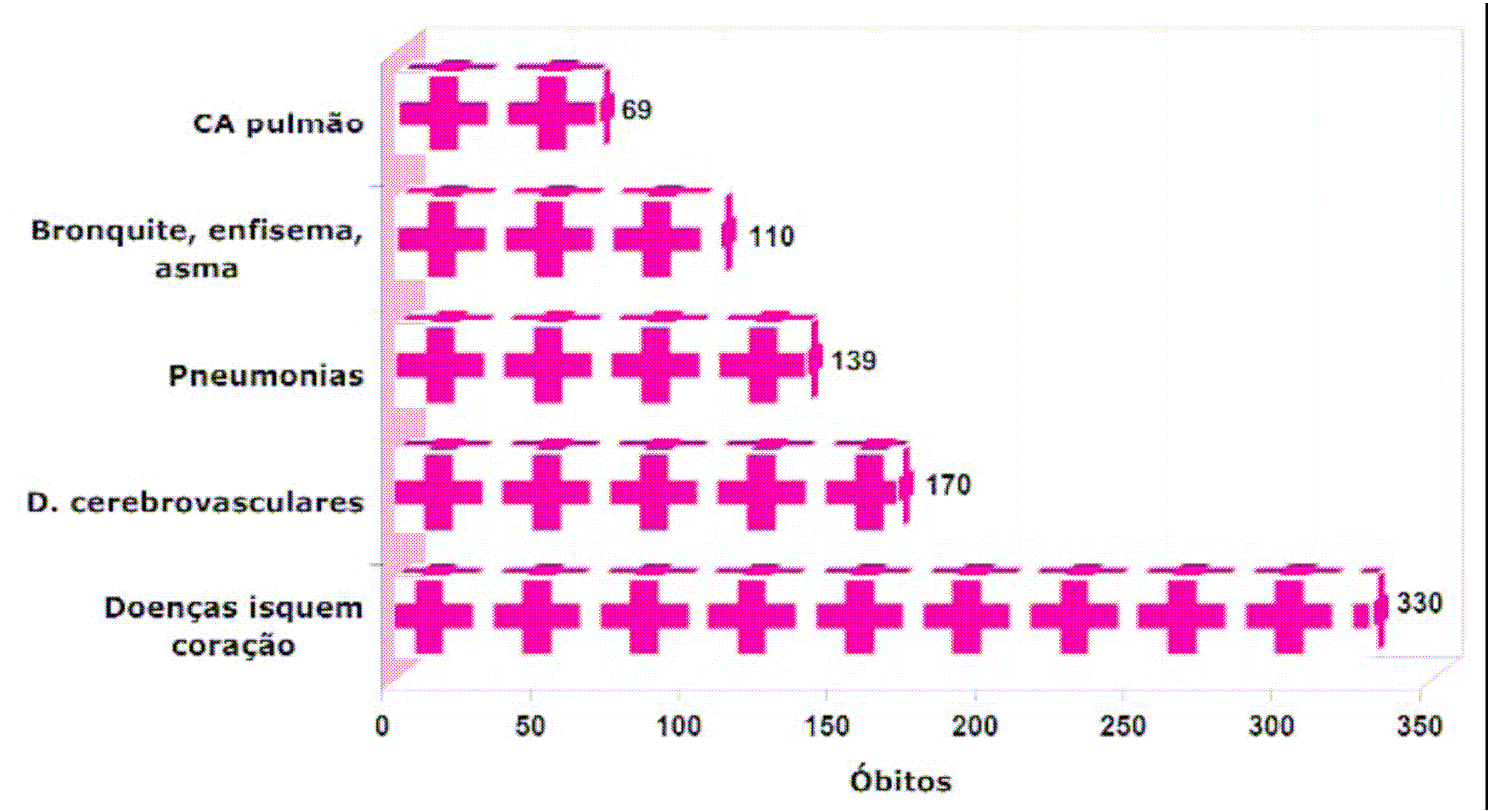

Extraído de: Seade, 2004 (Instituto Brasileiro de Geografia e Estatística -IBGE - 2000 e PROAIM/

Secretaria Municipal da Saúde/PMSP, 2003). 


\subsection{CARACTERIZAÇÕES DOS IDOSOS DO ESTUDO}

Participaram da amostra 31 sujeitos, sendo 5 homens (16,13\%) e 26 mulheres $(83,87 \%)$. Como podemos observar, dos 31 idosos entrevistados, a grande maioria foi composta pelo sexo feminino, o que comprova todos os dados estatísticos (Tabela 4 ).

Segundo dados do IBGE (2006), "No Brasil, em média, as mulheres vivem 8 anos a mais que os homens. As diferenças de expectativa de vida entre os sexos mostram que em 1991 as mulheres correspondiam a 54\% da população de idosos; em 2000 passaram para 55,1\%... Em 2000, para cada 100 mulheres idosas havia 81,6 homens idosos..." (p.1).

Tabela 4 Número e proporção de idosos entrevistados e matriculados no CSEGPS, segundo o sexo. Região de Pinheiros, São Paulo, Brasil, 2005.

\begin{tabular}{lcc}
\hline Sexo & N & \% \\
\hline Masculino & 5 & 16,1 \\
Feminino & 26 & 83,9 \\
\hline TOTAL & $\mathbf{3 1}$ & $\mathbf{1 0 0}$ \\
\hline
\end{tabular}

A Figura 5 mostra a pirâmide populacional da região de Pinheiros, comprovando nossas informações. É interessante como revela ser o envelhecimento predominantemente feminino.

Podemos verificar também o número elevado de idosos acima de 75 anos, com predomínio de mulheres. 
Figura 5 Pirâmide populacional da região de Pinheiros, São Paulo.

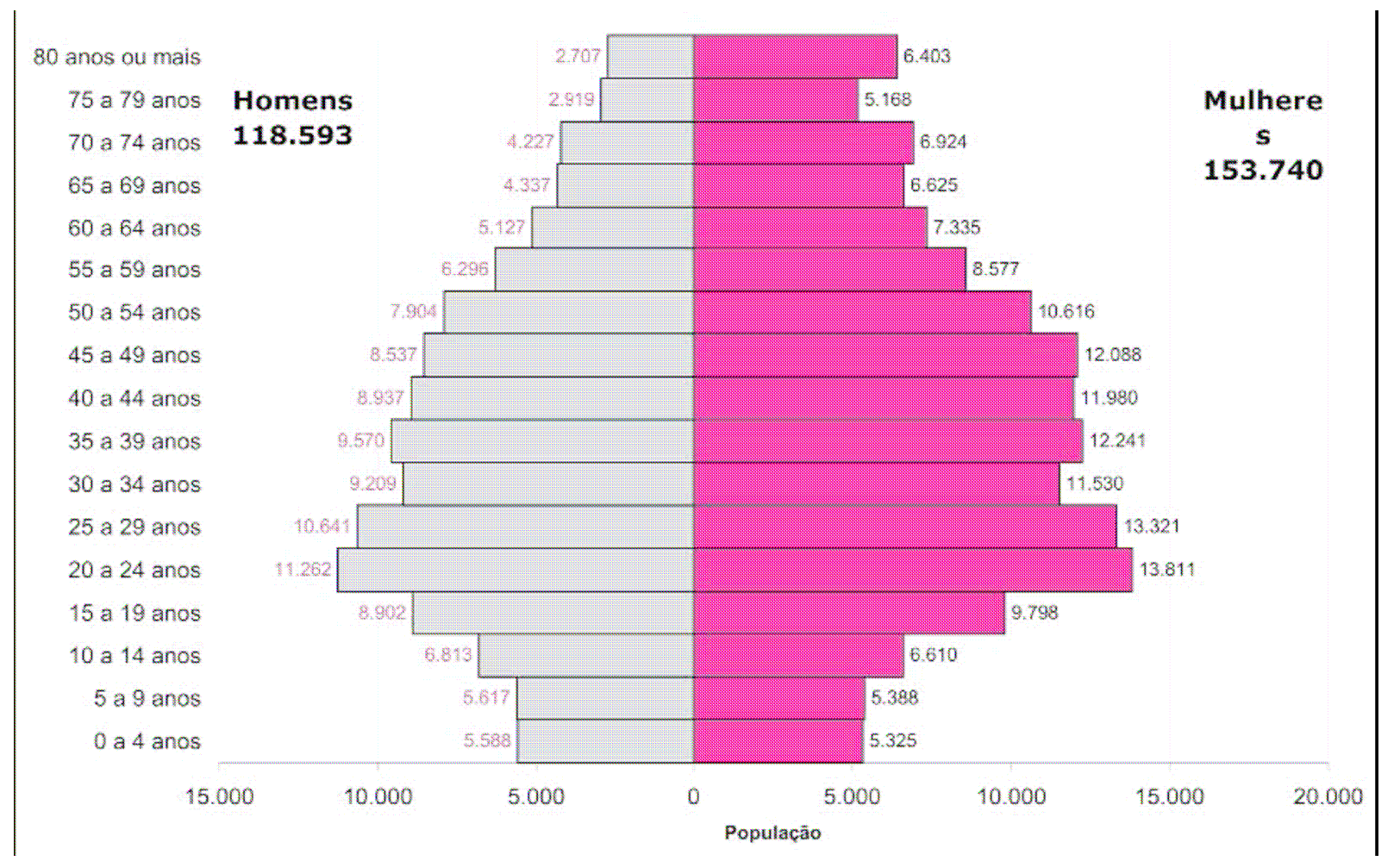

Extraído de: Seade, 2004.

A Tabela 5 demonstra que as idades variaram de 65 a 94, anos sendo a maior concentração na faixa etária dos 76 - 95 anos. Cabe-nos esclarecer que a variável faixa etária foi intencional, pois as incapacidades para Atividades de Vida Diária (AVD) e Atividades Instrumentais de Vida Diária (AIVD) são mais comuns nos idosos mais velhos, a saber, acima de 75 anos. 
Tabela 5 Número e proporção de idosos entrevistados e matriculados no CSEGPS, segundo a faixa etária. Região de Pinheiros, São Paulo, Brasil, 2005.

\begin{tabular}{lcc} 
Faixa Etária & $\mathbf{N}$ & $\mathbf{\%}$ \\
\hline $65-75$ & 6 & 19,4 \\
$76-85$ & 12 & 38,7 \\
$86-95$ & 13 & 41,9 \\
\hline TOTAL & $\mathbf{3 1}$ & $\mathbf{1 0 0}$ \\
\hline
\end{tabular}

A Tabela 6 refere-se ao Grau de Instrução dos Idosos, que na sua grande maioria tinham poucos anos de estudo. A maior concentração está entre 1-4 anos de estudo, correspondendo a 58,1\%. Podemos observar também um fato interessante quanto à igualdade de porcentagens dos extremos: idosos analfabetos $(9,7 \%)$ e idosos com mais de 13 anos de estudo $(9,7 \%)$.

O resultado do censo de 2000 realizado pelo IBGE mostra que o número de anos de estudo dos idosos responsáveis pelo domicílio é muito baixo, apenas 3,4 anos (3,5 anos para os homens e 3,1 anos para as mulheres) (IBGE, 2002).

Os idosos entrevistados não eram responsáveis pelo domicílio, mas apresentaram os mesmos índices. Este dado é importante na medida em que constatamos que por apresentarem algum tipo de fragilidade não mais ocupavam essa posição em sua família.

Tabela 6 Distribuição e proporção dos idosos entrevistados e matriculados no CSEGPS, segundo o Grau de Instrução região de Pinheiros, São Paulo, Brasil, 2005.

\begin{tabular}{ccc}
\hline Grau de Instrução & N & \% \\
\hline Analfabeto & 3 & 9,7 \\
De 1 - 4 anos de estudo & 18 & 58,1 \\
De 5 - 8 anos de estudo & 6 & 19,3 \\
De 9 - 12 anos de estudo & 1 & 3,2 \\
De 13 a mais anos de estudo & 3 & 9,7 \\
\hline Total & $\mathbf{3 1}$ & $\mathbf{1 0 0}$ \\
\hline
\end{tabular}


Todos os idosos possuíam recursos financeiros e a sua renda ajudava em muito no aumento do orçamento familiar contribuindo para a melhoria das condições de vida da família. Seus recursos provinham na sua grande maioria de aposentadoria e pensão. As viúvas eram as que usufruíam da pensão. Um fato que merece ser destacado é que os idosos, além destas duas fontes de renda ainda possuíam outras fontes para completar suas despesas, do tipo: poupança, receber ajuda em dinheiro ou espécie, aluguel, benefício assistencial.

A Tabela 7 mostra a combinação dos recursos, lembrando que muitas vezes um mesmo idoso tinha mais de uma fonte de recurso.

Tabela 7 Distribuição dos recursos financeiros dos idosos entrevistados e matriculados no CSEGPS, Região de Pinheiros, São Paulo, Brasil, 2005.

\begin{tabular}{|c|c|c|c|c|c|}
\hline Aposentadoria & Pensão & Poupança & $\begin{array}{c}\text { Recebe Ajuda } \\
\text { em Dinheiro e } \\
\text { Espécie }\end{array}$ & $\begin{array}{c}\text { Benefício } \\
\text { Assistencial }\end{array}$ & Aluguel \\
\hline 19 & 16 & 8 & 9 & 2 & 2 \\
\hline
\end{tabular}

Quanto aos cuidadores familiares, a Tabela 8 mostra a relação de parentesco com esses idosos, o que confirma as pesquisas sobre cuidadores, em que a grande maioria é do sexo feminino, geralmente filhas, seguidas dos cônjuges.

Identificamos um número considerável de cuidadores do sexo masculino, $\mathrm{n}=8$, com números percentuais iguais entre filhos e cônjuges, o que leva a supor que por falta de alternativas e por não possuírem outra pessoa para assumir o cuidado, foram obrigados a executá-los, transformando-se em cuidadores principais. 
Tabela 8 Demonstração do grau de parentesco dos idosos entrevistados e matriculados no CSEGPS, com seus cuidadores familiares, região de Pinheiros, São Paulo, Brasil, 2005.

\begin{tabular}{ccc}
\hline Grau de Parentesco & N & \% \\
\hline Filha e Filha adotiva & 20 & 64,6 \\
Filho & 4 & 12,9 \\
Esposo & 4 & 12,9 \\
Esposa & 1 & 3,2 \\
Nora & 1 & 3,2 \\
Neta & 1 & 3,2 \\
\hline Total & $\mathbf{3 1}$ & $\mathbf{1 0 0}$ \\
\hline
\end{tabular}

Acreditamos que com a apresentação destes dados sobre sexo, faixa etária, grau de instrução, recursos financeiros, e relação de parentesco dos idosos com seus cuidadores pudemos caracterizá-los, dando uma idéia mais clara de seus perfis.

A fim de avaliarmos os idosos com vistas a ajudar a compor seu perfil, optamos por utilizar dois instrumentos, aplicados durante a entrevista. O primeiro foi a Escala de Avaliação de Incapacidade Funcional e Dependência - Akhtar e col. - (ver anexo 5) utilizada na avaliação da capacidade funcional dos idosos e segundo os pesquisadores, é classificada para aplicação na comunidade, é de fácil aplicação e pode ser feita por qualquer membro da equipe de saúde, entre outras vantagens (LITVOC e DERNTL, 2002, p. 305).

Com esta escala foi possível avaliar a capacidade funcional em quatro domínios: Mobilidade, Controle de Eliminações, Atividades Instrumentais de Vida Diária (AIVD) e Autocuidado.

A partir dessa avaliação pudemos identificar a situação de fragilidade em que se encontravam os idosos, quanto de perda funcional eles apresentavam, e o quanto esta perda representava em termos de trabalho e de fonte geradora de estresse para o cuidador familiar.

Os profissionais que trabalham com os idosos sabem o que representa a perda gradativa da sua capacidade funcional. As perdas das AIVDs são sentidas, mas as perdas 
para as Atividades de Vida Diárias (AVDs) e do Autocuidado são mais impactantes para eles.

A Escala de Akhtar e col. possibilitou avaliar com cuidado as nuances das perdas progressivas, especialmente no item Autocuidado, onde a avaliação foi dividida em: totalmente independente; incapacidade mínima; dependente; totalmente dependente.

A Tabela 9 mostra as quatro dimensões da Escala de Akhtar e col., mais a variável "queda ocorrida nos últimos 12 meses", que também é um agravo significativo na vida do idoso, pois a sua ocorrência pode trazer prejuízos e incapacidades em geral permanentes, fazendo com que o idoso passe da condição de independente para a de dependente.

Na dimensão: controle de eliminações, 25 idosos (80,6\%) mostraram ser capazes de ter o controle de esfíncteres. Na dimensão: AIVDs, 29 idosos $(93,5 \%)$ possuíam perdas. Na dimensão: mobilidade, 19 idosos (61\%) mostraram-se capazes de se locomoverem dentro e fora de casa, e 12 idosos (39\%) asseguraram não ser capazes. Na dimensão: Autocuidado, 16 idosos (51,6\%) conseguiam executar as atividades de banho, alimentação, eliminação sozinhos, e 15 idosos $(48,4 \%)$ apresentavam fragilidade, variando de incapacidade mínima a totalmente dependente. Quanto às quedas, 9 idosos (29\%) as sofreram nos últimos 12 meses.

Tabela 9 Avaliação da capacidade funcional dos idosos entrevistados e matriculados no CSEGPS, região de Pinheiros, São Paulo, Brasil, 2005.

\begin{tabular}{|c|c|c|c|c|c|c|c|c|c|c|c|}
\hline \multicolumn{2}{|c|}{ Mobilidade } & \multicolumn{2}{|c|}{$\begin{array}{c}\text { Controle } \\
\text { de eliminação }\end{array}$} & \multicolumn{2}{|c|}{ AIVDs } & \multicolumn{4}{|c|}{ Autocuidado* } & \multicolumn{2}{|c|}{$\begin{array}{l}\text { Quedas no } \\
\text { último ano }\end{array}$} \\
\hline Cap. & Incap. & Cap. & Incap. & Cap. & Incap. & Cap. & Incm. & Indp. & $\mathrm{Td}$. & Pres. & Ausente. \\
\hline 19 & 12 & 25 & 6 & 2 & 29 & 16 & 7 & 7 & 1 & 9 & 22 \\
\hline \multicolumn{2}{|c|}{$\begin{array}{c}\text { Total } \\
\mathbf{3 1}\end{array}$} & \multicolumn{2}{|c|}{$\begin{array}{c}\text { Total } \\
\mathbf{3 1}\end{array}$} & \multicolumn{2}{|c|}{$\begin{array}{c}\text { Total } \\
31\end{array}$} & \multicolumn{4}{|c|}{$\begin{array}{c}\text { Total } \\
31\end{array}$} & \multicolumn{2}{|c|}{$\begin{array}{c}\text { Total } \\
\mathbf{3 1}\end{array}$} \\
\hline
\end{tabular}

*Cap = Capaz; Incm = Incapacidade mínima; Indp = Independência Parcial; Td = Total dependência. 
Os dados de nossa pesquisa são semelhantes ao que foi encontrado no PNAD de 1998, em seu suplemento especial sobre saúde, onde uma das questões levantadas foi investigar sobre algumas condições de deficiência e autonomia física da população brasileira. Na população idosa as dificuldades no desempenho das AVDs como: alimentar-se, tomar banho e/ou ir ao banheiro sozinho crescem nos segmentos de idosos com mais idade e são mais elevadas entre mulheres. Entre a população com mais de 80 anos, 30,1\% dos homens e 36,1\% das mulheres não são capazes de desempenhar sozinhos as AVDs (CAMARANO et al., 2004).

O segundo instrumento utilizado foi o Teste do Relógio - Clock Completion Test (CCT) que é um teste utilizado em populações para avaliação global da função cognitiva e para rastreamento de alterações cognitivas. “...Ele avalia a memória, a compreensão verbal, o pensamento abstrato, a praxia viso-espacial e as funções executivas..." (FUZIKAWA, 2002)

Este teste é frequentemente utilizado em pesquisas internacionais e nacionais para "screanning" de grandes populações. A literatura relata sua praticidade por se tratar de instrumento de fácil aplicação e de boa aceitação pelos idosos. Contudo estudos recentes começam a apontar uma fragilidade do teste quando usado em populações de baixa escolaridade (LOURENÇO et all, 2003; FUZIKAWA, 2002).

Em nossa pesquisa, o referido instrumento teve um papel coadjuvante na avaliação dos idosos e não foi utilizado como um instrumento de inclusão ou exclusão na amostra. Percebemos na ocasião do trabalho de campo que mesmo para os resultados do teste que levariam a uma eventual exclusão da pessoa idosa na pesquisa, estas mesmas pessoas durante a entrevista se revelaram coerentes e lúcidas mantendo o comportamento e o humor satisfatórios. Justificamos esta decisão considerando ainda que os mesmos além da baixa escolaridade tinham idades muito avançadas e não possuíam, na sua grande maioria, o hábito de ler e escrever cotidianamente, o que dificultava ainda mais a feitura do teste. Durante a entrevista pudemos verificar sua ansiedade quando solicitados a fazer o teste na frente do entrevistador. $\mathrm{O}$ fator ansiedade influiu muito para que alguns idosos se recusassem a fazê-lo. 
Outro fator também considerado foi quanto à legitimidade dos discursos, ou seja, que fatores ligados à idade não prejudicaram seu nível de compreensão e elaboração, não havendo indícios de dissociação de pensamento. Desta forma os depoimentos foram considerados pela sua clareza e consistência interna, dando-nos a certeza de que suas falas eram autênticas, legítimas e dignas de serem avaliadas e consideradas. Ademais questionou-se com cada um deles a importância que o cuidador familiar tinha para ele e para a sua vida.

Diante das considerações expostas referentes às capacidades cognitivas dos idosos entrevistados, embora muitos resultados do referido teste tenham apresentado scores abaixo do normal sugerindo início de comprometimento, decidimos não considerá-lo como instrumento de inclusão e exclusão para a participação dos idosos na pesquisa. Mediante isto o uso do teste óclock foi descartado como instrumento para o rastreamento de déficit cognitivo.

Os resultados de nosso estudo onde obtivemos baixa proporção de testes com escore 1 foram similares aos encontrados por Fuzikawa, 2002. Em sua pesquisa a autora questionou o uso deste teste em populações com baixa escolaridade e LOURENÇO et al 2003 referiram "que não há clareza quanto ao seu desempenho em idosos ambulatoriais com baixa escolaridade... os dados obtidos não aconselham tal uso em idosos iletrados" (p. 26). 


\subsection{DISCURSOS DO SUJEITO COLETIVO}

Apresentaremos a seguir todos os discursos feitos, com suas respectivas Idéias Centrais, ou melhor, as categorias, e os comentários pertinentes nas três questões analisadas.

Questão 1: $\operatorname{O} / A \quad \operatorname{Sr}(a)$ é cuidado(a) pelo(a) ............. Ele(a) é um bom cuidador(a)? Fale-me um pouquinho sobre isso.

Objetivo: Perceber o que o idoso pensa sobre o cuidado dispensado pelo cuidador familiar quanto aos sentimentos e emoções envolvidos no cuidado.

Foram encontradas 9 categorias/representações nos discursos:

A - Afeto direcionado para aquele que é cuidado;

B - Objeto fácil para o cuidado;

C - Vocação para o cuidado;

D - Cuidador competente - bom tarefeiro;

E - Obrigação/Retribuição

F - Diálogo - Troca de Papéis;

G - Tensão e Desgaste;

H - Solidão;

I - Família cuidadora. 


\section{CATEGORIA 1A}

\section{DSC 1A - AFETO DIRECIONADO ÀQUELE QUE É CUIDADO}

Critério de inclusão nesta categoria: afeto entendido como dedicação, preocupação, atenção, carinho, zelo e muitas vezes sacrifício no cuidado com seus idosos.

Boa cuidadora, excelente, maravilhosa. Para falar sobre os cuidados que ela me dispensa, eu tenho que primeiro vencer a emoção, tal é o carinho que ela tem pela minha pessoa e pela minha esposa ela é de uma constância que chega até a comover a gente . Ela é uma filha carinhosa, fica preocupada comigo é até um pouco exagerada. Quando ela me vê assim doente, ela fica desesperada enquanto não leva no médico, não sossega. Eu às vezes estou ruim dos quadris aí ela bate, massageia porque eu sinto dor. E os remédios tudo na hora certa também se eu esqueço ela lembra. Ela me dá banho, me hidrata, para ficar com a pele boa. Se eu acordar a noite, ela olha o que está acontecendo pula da cama na hora e vem cuidar de mim. Tem um cuidado comigo...E a alimentação, precisa de ver como ela cuida. O médico falou que eu comesse uma manga todo dia em jejum, por causa do intestino ela anda o mundo, mas ela acha a manga e traz para mim. E ajuda física, de fazer força, ela não pode, mas assim mesmo ela faz e eu fico muito aflita com isso porque eu sei que eu estou prejudicando a minha filha...e também ela não sai de casa sem dizer "mãe, eu vou até ali e já volto". Triste de mim se não tivesse a minha filha estava embaixo do chão... Foi Deus que me deixou ela... para cuidar de mim. Se eu não tivesse ela o que não sofria nesse mundo. Às vezes fico pensando, eu não sei até quando eu vou viver, mas Deus me livre se acaso ela for embora primeiro o que seria de nós dois sem ela? Então eu acho que outra pessoa não ia fazer assim... acho que enjoa de ficar...se ela não fosse boa não faria isso. Ela é tudo para mim... não me falta nada, tudo na minha mão. (Id.4; Id.6; Id 9; Id.13; Id.16; Id.19; Id.21; Id.23; Id.24; Id.26).

Observação: este discurso foi construído com depoimentos de 10 idosos.

Os cuidadores familiares foram: 6 filhas, 2 filhos e 1 marido.

Ao lermos este discurso notamos que para esses idosos o cuidado é sempre referido como algo melhor que o cuidador possa estar fazendo por ele. O afeto e o bem-querer superam todos os obstáculos que o cuidador enfrenta no seu dia-a-dia. 


\section{CATEGORIA 1B}

\section{DSC 1B - OBJETO FÁCIL PARA O CUIDADO}

Critério de inclusão nesta categoria: idosos que reconheceram que o cuidado de que necessitavam não era pesado para seus cuidadores familiares porque ainda estavam parcialmente independentes e não os estressavam muito.

...Para mim é uma filha, considero como uma filha porque eu também não sou muito chata. Eu acho que eu não sendo chata, ela tem mais paciência por que se a gente fosse chata é ruim se eu desse muito trabalho para ela também seria ruim. Tudo o que eu peço ela faz para mim. Toda hora ela está aqui me ajuda muito... É laranjada, é fruta partida, descascada, ela faz tudo, sobre isso eu não posso me queixar. Agora, graças a Deus, eu não preciso muito eu me viro sozinha. Tomo banho sozinha, tiro a minha calcinha, já vou lavar, ou deixo lavadinha no chuveiro, para não ficar dando tanto trabalho para ela, me visto sozinha e vou dormir sozinha, assim, não preciso estar chamando ela toda hora...só quando eu preciso que eu chamo, senão eu não chamo. E também tenho vontade de fazer serviço gosto de lavar uma roupa, é que para ficar passando roupa também eu não agüento muito de pé. Então eu faço alguma coisa, às vezes ela sai e eu falo "tem alguma coisa no fogo que eu preciso olhar", ou se tem pouquinha louça na pia eu dou uma lavadinha, encosto ali e dou uma lavada. Eu estou mais feliz aqui do que em casa porque em casa era muito sozinha era muito grande o apartamento. Então, como eu caí, eu vim para a casa da minha nora....Ela é demais eu conto com ela fica preocupada, mas confia em mim porque eu não saio, não dou trabalho, não vou para a rua sozinha... (Id.4; Id.14; Id.17; Id.28).

Observação: este discurso foi construído com depoimentos de 4 idosos. Os cuidadores familiares foram: 1 nora, 2 filhas e 1 neta.

A escolha do sujeito "sogra" para dar voz a esta representação foi proposital, dado aos diferentes tipos de cuidadores familiares (filhas, neta) que prestavam cuidados para estes idosos, porque este ilustraria o que os idosos pensavam e sentiam sobre os cuidados dispensados pelos seus cuidadores. 


\section{CATEGORIA 1C}

\section{DSC 1C - VOCAÇÃO PARA O CUIDADO}

Critério de inclusão nesta categoria: o reconhecimento por parte do idoso daquele familiar que sempre esteve e está disponível para exercer o cuidado. Ele se oferece para executar o cuidado.

...Ah, ela é uma boa cuidadora é demais é boa mesmo cuida muito bem de mim cuida com carinho, com dedicação, com amor. Sempre foi assim mesmo quando eu morava no interior, ela não morava aqui comigo, mas qualquer coisa que telefonava para ela que eu estava ruim, ela já vinha cuidava de mim e já levava para o médico se preocupava muito comigo. Ela sempre mandava dinheiro para mim, pra ajudar nas despesas tudo. Ela cuida bem de mim mesmo, cuida como deve ser cuidado não posso reclamar e não só para mim, sabe, mas para mim é mais. Então tem toda a confiança de deixar mas ela não gosta que eu reclame... (Id.09; Id.22; Id.25; Id.28)

Observação: este discurso foi construído com depoimentos de 4 idosos. Os cuidadores familiares foram: 3 filhas e 1 esposo. 


\section{CATEGORIA 1D}

\section{DSC 1D - CUIDADOR COMPETENTE - BOM TAREFEIRO}

Critério de inclusão nesta categoria: o reconhecimento por parte dos idosos das qualidades técnicas, da dedicação e da precisão do cuidado exercidas pelo seu cuidador familiar.

...É muito boa para cuidar de mim tem sido excelente porque ela é muito cuidadosa, muito carinhosa fala calma, explica muito. Eu tenho muita confiança nela. Tudo o que eu preciso ela está pronta para me ajudar. Parece uma enfermeira faz curativo todo dia pois eu uso sonda vesical ela limpa, desinfeta. É esperta, aprende num instante tudo, também segue o que o médico o que o enfermeiro manda, é detalhista e minuciosa no cuidado.Tem sido uma filha dedicadíssima porque me dá todos os predicados que eu preciso. Deu iniciativa e providenciou os médicos, as consultas, os remédios. Todo dia separa o meu remédio, me leva no banheiro me ajuda no banho, a escovar o dente, me arruma na cama pois não tenho força nas pernas. De manhã eu desço a escada, fico sentada nessa cadeira ela me dá café com leite, pão e manteiga não deixa eu comer o que faz mal. Providencia a alimentação que eu preciso as coisas especiais que eu gosto...frutas que eu quero ela traz da feira. Tudo o que eu peço ela me dá até roupa de baixo, pijama, essas coisas, tudo ela compra para mim... Ah! ela faz todo o serviço, faz a comida lava, passa tudo ela faz... Para sair para a rua não dá, ainda mais que quase eu não enxergo, eu tenho medo de me perder por isso sozinha eu não saio mais. Quando ela vai no supermercado, no shopping me leva para distrair um pouco. Então quando ela sai, a cabeça dela está sempre pensando em mim e eu acho que o cuidado é esse quando a gente está doente e tem quem lhe olhe... É uma boa filha, cuida muito bem, me atende, não é uma menina revoltada e nem nada. Graças a Deus em boa hora eu digo`nossa Senhora me ajude, ajude a ela, que seja sempre assim.`Eu estou muito feliz e muito contente. Eu sou muito bem cuidada por ela. (Id.1; Id.2; Id.3; Id.4; Id.5; Id.6; Id.7; Id.8; Id.11; Id.13; Id.15; Id.18; Id.22; Id.25; Id.26; Id.27; Id.28; Id.30).

Observação: este discurso foi construído com depoimentos de 18 idosos. Seus cuidadores familiares foram: 3 filhos, 12 filhas, 3 esposos.

Em nosso trabalho de mestrado pudemos identificar nos discursos dos cuidadores familiares esta mesma representação. 


\section{CATEGORIA 1E}

\section{DSC 1E - OBRIGAÇÃO/RETRIBUIÇÃO}

Critério de inclusão nesta categoria: os idosos reconhecem a importância do cuidado, justificando serem merecedores desta atenção. A prestação da assistência é encarada como obrigação dos filhos e retribuição por tudo o que receberam anteriormente.

...Boa cuidadora é demais ela cuida muito bem é muito atenciosa é espetacular é fora de série ela vale por 10. Se eu tivesse 10 filhos, eu acho que não faziam o que ela faz. Tudo o que eu quero ela me faz é a família da gente...é a filha, então desde sempre, por estar mais perto, tem que cuidar mais da gente é a responsável da casa, o serviço de casa, vai tudo na mão dela ela sabe como vai fazer. Na verdade, ela tem muito cuidado comigo porque eu criei ela quando ela tinha uns dois ou três anos eu ia almoçar em casa ela me agarrava na calça do macacão e não largava, chorava, queria um brinquedo. Por isso que hoje ela me recompensa. Eu ia na esquina e comprava um brinquedinho, qualquer coisinha, dava para ela, dava uma volta no quarteirão e ela dormia e eu ia trabalhar. Era assim... Todo domingo eu ia com ela no Ibirapuera, soltava aviãozinho, ela ficava olhando. E eu cresci com ela até moça, passeando e viajando muito com ela. Eu também cuidei muito dos filhos dela, cuidei toda a vida. Ela lecionava e eu que tomava conta das crianças ela ficou doente, ficou internada 9 meses num hospital em Araraquara e não larguei dela. Então tá a prova ai tudo o que ela faz, todo dia traz comida, traz pão, vê se precisa de alguma coisa, me aplica insulina, olha a mãe, traz o remédio para a mãe. Ela se preocupa, vai ao supermercado, vai ao Ceasa...mas ela me disse uma vez ..."eu já estou cheio de tomar conta de você." Então eu disse para ela - bom, eu agradeço bastante você tomar conta de mim, paciência, porque eu por mim, eu já fiz para você tantos anos, agora eu deixo você me fazer, não é? Aí ela fica quieta... mas quando eu estou doente, eu tenho tudo o que eu preciso. Eu tenho o carinho dela...tenho os cuidados...(Id.05; Id. 06; Id. 12; Id.20; Id.21; Id.29)

Observação: este discurso foi construído com depoimentos de 6 idosos. Seus cuidadores familiares foram: 3 filhas, 1 filho e 2 esposos.

Esta representação também foi encontrada em nosso trabalho de mestrado e é referendada por muitos estudiosos do envelhecimento que estudam os cuidadores. 


\section{CATEGORIA 1F}

\section{DSC1 F - DIÁLOGO/TROCA DE PAPÉIS}

Critérios de inclusão nesta categoria: o reconhecimento por parte do idoso de que o diálogo entre ambos é fundamental para o cuidado, e quando ocorre a troca de papéis, esta fica facilitada e amena para o cuidador.

...Olha, ela é maravilhosa e o que me ajuda também é que nós mantemos sempre um diálogo às vezes sobre certas coisas, que aconteceram, acontecem, então esse bate papo aí também ajuda, digamos, a gente a viver. Sinceramente, ela é ótima para mim ela é assim para mim... já é uma mãe daquelas mães que cuidam dos filhos pode ficar certa, já não é mais filha eu agora sou filha dela e ela agora é a minha mãe. Imagina, ela sabe, ela que me vê remédio. Agora, a gente tem uma hora de briga. Tem horas que eu quero comer alguma coisa e ela diz "...oh mãe, eu sei o que você pode, eu estou tomando conta de você...eu sei o que é bom para você, a senhora reclama tanto que quer ir morar sozinha, eu vou deixar a senhora morar sozinha, a senhora não sabe, $e$ nunca soube, agora depois de 87 anos a senhora vai fazer uma comida para a senhora não faz... "Sua roupa a senhora vai lavar direito para eu ver a senhora bem alvinha como eu gosto assim?...Então sou eu que vai ter que ficar, não adianta a senhora ser teimosa, pode chorar, pode fazer o que quiser é assim mesmo". ...Ela vai comigo comprar as coisas...vestido, por exemplo. Quando chegou lá ela olhou, o que eu olhei também, e ela "eu não sei se a senhora vai gostar dele". Eu vou gostar sim, pode deixar. "Mãe, vem aqui, sai, deixa a moça aí e vem aqui, a senhora vai gostar desse vestido sabe pra que? A senhora fica um dia ou dois, veste ele três, quarto vezes, e depois dá para outra pessoa. Não é assim que a senhora faz?"...Eu falei - não, não é tanto assim, não eu sei muito bem o que falo e o que faço...Então quando eu não posso fazer ela faz, quando ela não pode fazer, eu faço para ela...É assim...tem que ser assim mesmo... A mãe com o filho e o filho com a mãe. Tem que ser assim mesmo...( Id.01; Id.16; Id.24; Id.31)

Observação: este discurso foi construído com depoimentos de 4 idosos. Seus cuidadores familiares foram todas as filhas.

A troca de papéis na relação do cuidado é um fato freqüentemente referido pelos idosos no momento em que reconhecem estarem ficando mais dependentes e fragilizados. $\mathrm{O}$ diálogo neste momento é fundamental para que o cuidado flua em benefício de ambos. 


\section{CATEGORIA 1G}

\section{DSC 1 G - DESGASTE/TENSÃO}

Critério de inclusão nesta categoria: a constatação por parte do idoso da presença da tensão e do desgaste que surge na relação de cuidado que estabelece com o seu cuidador.

...É uma boa cuidadora, é atenciosa ela cuida bem de mim, só que ela é muito nervosa comigo. Ela acha que eu sou muito teimoso...no restante ela me trata muito bem até que nós vivemos já há 45 anos, só que ela briga muito comigo. Às vezes eu quero falar qualquer coisa assim, ou mesmo quando eu falo de telefonar para os amigos ela acha ruim. Acha ruim, porque não precisa falar. E eu fico triste com isso...de vez em quando ela se exalta, mas passa... Fala que eu sou muito chato (risos). Uma vez ela falou que eu sou chato e eu falei "eu sou chato mas não sou gilete". (risos) ...e vamos vivendo...casalzinho de pombinhos. ...É fogo, é assim as coisas, viu... Até que Deus nos tire do mundo... porque nós estamos aqui é uma passagem. Mas ela é uma boa esposa, uma boa cuidadora. Não resta dúvida. (Id. 4; Id.29).

Observação: este discurso foi construído com depoimentos de 2 idosos. Seus cuidadores familiares foram: 1 esposa e 1 filha.

Foi escolhido o sujeito "esposo" para dar voz a esta representação porque o conteúdo fica mais revelador. O desgaste e a tensão que o cuidado provoca na relação de cuidado é uma constante, prejudicando tanto o idoso como o cuidador. A exaustão do cuidador deverá ser observada e valorizada pelos serviços de saúde e pelos profissionais. 


\title{
CATEGORIA 1H
}

\author{
DSC $1 \mathrm{H}$ - SOLIDÃO
}

Critério de inclusão nesta categoria: percepção por parte do idoso da ausência de uma companhia para conversar, para estar presente, e mesmo para auxílio nas Atividades de Vida Diária (AVDs).

...É minha amiga mais ela vai aonde quer. Ela vai embora e eu fico sozinha. Vai às entrevistas que gosta e eu não obrigo nada. Ela deixa o almoço na mesa eu aqueço. Eu faço tudo. Só não faço esse trabalho pesado, temos faxineira. Eu pago. Eu fico em casa, deito sozinha. Eu acho que estou bem porque tenho noventa e tantos anos e faço tudo sozinha. Hoje, como quase todos os dias, sozinha. Só quero que elas (filhas) estejam em casa porque tenho medo de cair, mas eu entro sozinha no banheiro, tomo banho, me enxugo e vou para o meu quarto, que é logo ali ao lado para me vestir. Visto me, sento ao fundo da minha cama para pôr a calcinha. A calcinha sou eu mesma que cuido, que as lavo, ponho numa bacia com água e um pouco de sabão. Eu não as sujo, porque elas vão por cima da fralda. Eu não uso as fraldas todo tempo, só quando eu faço muito xixi. Eu acho que na minha idade, fazer isso, saber pendurar, pôr no arame... Eu faço muitas coisas para mim. Comida não. Tenho medo de me queimar. Minha mão não é firme. Às vezes eu até digo comigo mesma 'ai como minha mão não presta!' Às vezes deixo cair as coisas, mas quando aqueço a comida e ponho em cima da mesa, numa bandeja, eu tenho todo o cuidado para não deixar cair da mão. E nunca aconteceu. Nunca quebrei nada. Então acho que estou bem neste sentido... Às vezes, penso...que eu estou bem.(10)

Observação: este discurso foi construído com depoimento de uma idosa. Sua cuidadora familiar era uma filha.

A necessidade dos cuidadores de trabalhar e de ter vida própria faz com que os idosos passem boa parte do seu dia sozinhos, tendo que se responsabilizar pela sua segurança e pelas AVDs. Podemos observar neste discurso que esta situação gera desconforto e tristeza neles. A solidão é-lhes muito penosa. 


\section{CATEGORIA 1I}

\section{DSC 1 I - FAMÍLIA CUIDADORA}

Critério de inclusão nesta categoria: reconhecimento por parte dos idosos de que numa possível ausência do cuidador principal estes idosos têm o amparo de outros membros da família.

...O meu genro também é muito bom. É uma pessoa que, não é de falar que é genro ruim, que fala da sogra. Não, ele é muito bom. E o meu neto também, melhor ainda, porque quando eu fiquei ruim, ele me dava comida até na boca. Eu ia comer e a colher não acertava, pegava no nariz, e ele falava 'vó, eu vou te dar a comida'. E eu não estava nem conhecendo que era o meu neto... E as minhas filhas...ficam sempre preocupadas, se uma não pode vir aqui em casa, ela liga 'olha, mãe, ainda estou aqui no serviço, vou chegar muito tarde e não vou em casa hoje'...E a outra que mora em Maceió liga toda semana, 'mãe, está boa?'. Ontem até ela falou assim para mim 'mãe, está difícil falar contigo'.. ...Eu também tenho uma sobrinha, pediu que eu fosse morar mais ela ...Eu fui na casa dela, deixei a mala lá com tudo, para voltar, mas imagina eu deixar o meu filho aqui só...A minha filha de Maceió vem agora aí, vai ficar 2 meses comigo aqui. Não vejo a hora que ela chega...(Id.4;Id.19;Id.23)

Observação: este discurso foi construído com depoimentos de 3 idosos. Seus cuidadores familiares foram: 2 filhas e 1 filho. Com relação ao amparo de outros membros familiares, verificamos que estes idosos enfatizam a importância desta rede no seu cotidiano de vida.

O que observamos é que além de possuírem um cuidador familiar responsável pelo cuidado diário, estes idosos têm também todo o amparo familiar por trás. 
Questão 2 Como seria se o Sr(a) não estivesse sendo cuidado pelo(a)....... ?

Objetivo: Identificar em que medida este cuidador familiar é importante como cuidador

Foram encontradas 9 categorias/representações nos discursos:

A - Seria difícil, pois não tenho ninguém;

B - Teria que ir para a casa de repouso;

C - Teria que encontrar outro cuidador;

D - Teria a minha família;

E - Cuidar é uma obrigação;

F - Seria difícil, só ela sabe cuidar de mim;

$\mathrm{G}$ - Deus toma conta;

$\mathrm{H}$ - Estaria morando sozinha;

I - Seria muito difícil porque sou dependente dos outros. 


\section{CATEGORIA 2A}

\section{DSC -2 A- SERIA DIFÍCIL, POIS NÃO TENHO NINGUÉM}

Critério de inclusão nesta categoria: o reconhecimento por parte do idoso de que na ausência deste cuidador familiar não teria outra pessoa e a única alternativa seria ficar sozinho.

Eu não sei o que seria de mim.. eu acho que eu morria à mingua porque não tinha ninguém para cuidar. É dose a gente ser sozinha porque não tem mãe, pai, não tem marido e estou velha. Tenho irmã, netos mais nem sempre estão bem para ajudar e a gente também não pode ficar perturbando eles para fazer certas coisas... Então é ela que cuida de mim todo dia ela separa o meu remédio...Se não tivesse ela teria que me arrumar sozinha teria que me esforçar mais para não esquecer de tomar o remédio, para lembrar de outras coisas, me preocupar... Pegaria um táxi iria ao supermercado sozinha, faria a compra e fazia a comida... Mas ela me cuida muito bem, graças a Deus. Deus que ajude ela, que dê bastante saúde porque para enfrentar o que ela enfrenta aqui, é dose. Ela é até forte demais... Se não fosse ela eu estava aí, só jogada no mundo. Às vezes eu penso meu Deus quem vai morrer primeiro, eu preciso morrer primeiro porque eu não posso ficar sem ela, porque eu não posso andar por aí e os meus filhos têm a vida deles. Então eu vou sentir muita falta dela se ela for...se morrer primeiro que eu. Eu preciso muito dela. Não faço idéia de como será a vida sem ela...(Id.1; Id.3; Id.7; Id.9; Id.15; Id.18; Id.19; Id.21; Id.25)

Observação: este discurso foi construído com depoimentos de 9 idosos. Seus cuidadores foram: 7 filhas, 1 filho e 1 esposo.

O reconhecimento da importância dos cuidadores por parte dos idosos nos permite afirmar que sem eles provavelmente seria difícil encontrar na família outra pessoa para executar e se responsabilizar pelo cuidado. 


\section{CATEGORIA 2B}

\section{DCS 2B - TERIA QUE IR PARA CASA DE REPOUSO}

Critério de inclusão nesta categoria: a constatação dos idosos de que a única alternativa que lhes resta é a casa de repouso.

Se eu não fosse cuidada por ele...hum, como que eu vou responder isso?...não tenho idéia, nunca pensei nisso também...eu tinha que ir para a casa de repouso, um hospital, uma entidade, talvez em algum sanatório enfiada... Quem ia me cuidar? uma enfermeira em casa é muito caro fica um pouco difícil. Morar sozinha eu acho que não conseguiria porque com a minha doença eu não posso levantar a qualquer hora, a pessoa não vai querer. Não teria mais ninguém para cuidar de mim. Os filhos têm a sua vida acho que não ficariam procurando por mim para me cuidar. Para dizer a verdade, para a casa dos meus filhos eu acho que não porque nora é diferente de filho, de filha. Acho que não tem o que falar... Então só se eu fosse para uma casa de... Não digo asilo porque asilo é meio pesado. Mas para uma casa de... como é que a gente fala? Uma casa de idosos onde ficam as pessoas de idade. ...Que eu pagasse para ficar nessa casa. Não assim como um asilo que fica lá, um idoso que não tem...que não tem condições de pagar. Ah, eu acho que tinha que ser que não tinha outro jeito... quer dizer, que se não tivesse ele eu estava no asilo hoje. Não sei se eu estava viva ou se eu estava morta, eu não sei, eu sei que eu estava lá...(Id.5; Id.6; Id.8; Id.11; Id.26; Id.27; Id.30)

Observação: este discurso foi construído com depoimentos de 7 idosos. Seus cuidadores familiares foram: 2 filhas adotivas, 3 esposos, 1 filho e 1 filha.

Neste discurso fica bastante explícito que na ausência do cuidador principal só resta a casa de repouso para eles. É interessante notar que para estes idosos há uma diferença entre asilo e casa de repouso. Em sua fala, asilo é para pessoas pobres e casa de repouso para quem tem dinheiro e, portanto, haverá um atendimento diferenciado. 


\section{CATEGORIA 2C}

\section{DSC 2C - TERIA QUE ENCONTRAR OUTRO CUIDADOR}

Critério de inclusão nesta categoria: reconhecimento por parte do idoso da necessidade de encontrar outros recursos e pessoas para desempenhar o cuidado.

Teria que arranjar uma pessoa amiga, ir para a casa de um filho, ou para a casa de uma irmã. Colocar uma empregada, uma pessoa aposentada. Alguém que conhecesse para se responsabilizar pela gente, para acompanhar, para fazer companhia, pelo menos ficar junto para cuidar... Então eu teria que buscar outros recursos de sobrevivência e escolher um deles que fosse a melhor opção porque eu acho que a pessoa não pode se entregar de todo... ele deve descobrir aquilo que precisa, o que pode fazer, e o que pode receber porque eu não tenho condições eu tenho um pouco de dificuldade para andar, não tenho mais estabilidade como tinha de primeiro. Preciso andar de bengala tenho muita dor nas costas não vou sozinha no banheiro, e quando estou com sede, preciso pedir água para alguém...não tenho condições de pegar um ônibus e ir para cá e para lá. ...Então é uma coisa mais complicada para mim se não tivesse ele porque é uma grande ajuda que ele me dá... Precisaria de outra pessoa para ficar comigo nem que fosse pelo menos até um meio-dia. Não tinha jeito teria que arrumar alguém... (Id.1; Id.2; Id.4; Id.10; Id.12; Id.16; Id.20; Id.24; Id.29)

Observação: este discurso foi construído com depoimentos de 9 idosos. Seus cuidadores familiares foram: 7 filhas, 1 filho e 1 esposa.

A essência deste discurso é a autonomia dos idosos em encontrar novos caminhos para ajudá-los no cuidado de que necessitam. A procura de novas alternativas para suas vidas de dependentes é que dá o tom neste discurso. 


\section{CATEGORIA 2D}

\section{DSC 2D - TERIA A MINHA FAMÍLIA}

Critério de inclusão nesta categoria: a percepção do idoso de que na ausência do seu cuidador há a possibilidade de a família extensiva assumir o cuidado.

...Seria difícil isso é duro não tenho idéia...Seria estar ao pé de um outro, sei lá, da família da gente...Eu tenho mais parente tenho dois irmãos, oito sobrinhos, um filho, uma filha, meu neto, várias pessoas aí que são vizinhas e que são preocupadas comigo. Gostam de mim e se eu precisar delas, elas me acolhem também. Na minha família nunca aconteceu isso de maltratar, de não cuidar. Porque todo mundo que fica doente um ajuda o outro. Então não tenho idéia. Eu vejo falar... falar a gente vê, mas eu não posso falar nada porque nunca aconteceu, agora que está acontecendo. Então eu não tenho idéia assim se eles pudessem me pôr em algum lugar...mas isso nunca vão fazer...por enquanto eu estou aqui... Já tem um tempo que eu estou aqui com ele...por isso eu digo, que não deixo o meu filhinho só não...Eu tenho muito parente...muito parente...mas não vou deixar ele sozinho...(Id.7; Id.20; Id.22; Id.23; Id.28; Id.29)

Observação: este discurso foi construído com depoimentos de 6 idosos. Seus cuidadores familiares foram todos os filhos.

A família extensiva também aqui é lembrada e o idoso tem nela o seu último recurso. $\mathrm{O}$ fato de achar que tem nela um respaldo não o deixa tranqüilo na ausência do seu cuidador. É uma possibilidade mas não uma certeza. No discurso isto fica claro. 


\section{CATEGORIA 2E}

\section{DSC 2E - CUIDAR É UMA OBRIGAÇÃO}

Critério de inclusão nesta categoria: afirmação por parte dos idosos de que cabe aos filhos a tarefa de cuidar de seus pais.

...Ah, eu brigava fazia um escândalo porque ou tem que me ajudar ou senão pinica....tem que ir embora. Porque eu gosto muito de brigar. Eu gosto das coisas direitas. Não gosto de nada errado. Ou bem ou mal. Se faz por bem, fica por bem, se faz por mal, some da minha frente. Mas ele nunca diz não ele é bonzinho...sempre me ajuda bem. Ainda bem que eu criei ele...Tenho duas irmãs, sobrinhas, tenho tudo. Mas eu acho que a obrigação é do meu filho. Eu tenho meu filho, nem ficaria bem eu ir para a casa dos outros ele estando aqui...(Id.14; Id.17; Id.26)

Observação: este discurso foi construído com depoimentos de 3 idosos. Seus cuidadores familiares foram: 1 filho/nora; 1 neta/filho; 1 filha adotiva.

Para estes idosos é obrigação dos filhos e somente deles cuidar de seus pais. Não cogitam de outra pessoa para esta tarefa. A má vontade ou ausência do cuidado são encaradas com algo errado praticado pelos filhos. 


\section{CATEGORIA 2F}

\section{DSC 2F - SERIA DIFÍCIL SÓ ELA SABE CUIDAR}

Critério de inclusão nesta categoria: a constatação do idoso de que seu cuidador é especial e somente ele é capaz de tanta dedicação e disposição para esta tarefa.

...Ah, não daria não seria diferente porque não teria a mesma paciência de estar procurando fazer tudo para agradar, porque além de tudo isso é uma palavra de conforto, de carinho... Não tinha chegado a essa idade assim como estou, não. Eu teria chegado muito mais acabada, muito mais. Seria só ela... Eu digo com sinceridade, só ela. Ainda tem mais. Porque além dela ser assim como pessoa, ela fazer isso comigo... E os irmãos... Depois que o pai morreu ela, que toma a frente...e diz "mãe você não agüenta mais, você está cansada..."(Id.11; Id.31)

Observação: este discurso foi construído com depoimentos de 2 idosos. Seus cuidadores familiares foram: 1 esposa e 1 filha.

A exaltação à figura do cuidador é que para estes idosos este indivíduo é o que agrega todas as qualidades para o cuidado. Nenhum outro será mais eficiente, paciente e melhor para a tarefa. É único.

\section{CATEGORIA 2G}

DSC 2G - DEUS TOMA CONTA

Critério de inclusão nesta categoria: a afirmação por parte do idoso que na ausência de seu cuidador somente um Ser Maior poderia ajudá-lo.

...O jeito é ficar aí como Deus quer... Deus toma conta também. Agora eu estou mais ela, como se diz... Está bom, porque ela está, abaixo de Deus, é ela que está olhando para mim...(Id.1) 
Observação: este discurso foi construído com depoimento de uma idosa cuidada por sua filha.

Esta representação foi encontrada também no pré-teste. É uma representação social com pouca intensidade (apenas 1 idoso), mas que merece ser destacada pela intensidade e simplicidade como é retratada a figura do cuidador. "Abaixo de Deus está ela para me olhar e me cuidar."

\section{CATEGORIA 2H}

\section{DSC 2H - ESTARIA MORANDO SOZINHA}

Critério de inclusão nesta categoria: o aparecimento da dependência e da fragilidade obrigando o idoso a aceitar viver com a família.

Ah, não sei... Eu só sei que se não fosse essa dor no peito, e a hipoglicemia que começou a me dar eu estava morando sozinha até hoje. Eu passei numa médica, ela falou que por minha mentalidade, inteligência, eu teria condições de ficar sozinha, mas a minha filha falou que não, que não dava. O meu genro também falou "olha, a senhora não vai poder ficar sozinha mesmo, e se cai aí uma hora de noite, que vai no banheiro e cai. Vai ficar a noite toda aí, porque a senhora não vai conseguir chegar no telefone." Onde eu morava era sobrado, apesar de que eu tinha telefone em cima e embaixo, tinha extensão .Então tive que vir junto com ela mais eu nunca incomodei eles... Às vezes eu deixo dinheiro para ela, para comprar alguma coisa que precisa.. para pagar água, luz... ela fala "não, não quero mãe, não precisa, não... fica para pagar o remédio...” só essa semana de remédio foi 170 reais, só de dois três remedinhos... A minha filha e o meu genro fazem tudo, eles não sabem o que fazer mais, ficam desesperados por causa dessa dor que eu tenho... Então não sei...(Id.3; Id.4)

Observação: este discurso foi construído com depoimentos de 2 idosas. Seus cuidadores familiares foram as filhas e os genros.

Neste discurso podemos verificar a diferença entre autonomia e independência. Estas idosas possuíam autonomia para levar sua vida, embora começassem a apresentar dependência para algumas atividades de autocuidado, necessitando desta forma da 
presença de um cuidador. O conteúdo deste discurso também mostra como é difícil para o idoso aceitar sua dependência e deixar sua casa e seus pertences para ir morar com um filho.

\section{CATEGORIA 2I}

\section{DSC 2I - SERIA MUITO DIFÍCIL PORQUE SOU DEPENDENTE DOS OUTROS}

Critério de inclusão nesta categoria: o reconhecimento por parte do idoso de sua incapacidade para o autocuidado e a importância que o cuidador tem em sua vida.

Como seria? Eu ia ter a maior dificuldade do mundo. Porque a mulher, a gente quando é independente, faz tudo por conta própria e depois começa a depender preciso disso, preciso daquilo... para mim é difícil viver pedindo. Eu sei que eu estou sendo inoportuna apesar de não ter culpa. Elas (filhas) sabem disso, mas eu sei que seria bem melhor se eu ocupasse elas menos do que eu ocupo porque eu não estou sendo capaz de me locomover sozinha, de pegar a cadeira de roda e mexer sozinha, de coçar a minha cabeça, de coçar o meu corpo, porque os meus braços, os meus dois braços, os ombros, ficaram muito atingidos, muito prejudicados. Sinto muita dor, muita dor...mas assim mesmo eu mexo com ele com muita dificuldade, não posso levantar ele muito e o braço que estava imobilizado, esse daí eu vou ter que fazer fisioterapia. Todos os dois braços estão muito difíceis de locomover... A artrose é uma doença muito, muito... Judia demais da pessoa...(Id.13)

Observação: este discurso foi construído com depoimento de uma idosa cuidada pela filha.

Este discurso é permeado de muita dor e ressentimento do que representa para o idoso ser dependente de alguém. Esta situação de fragilidade e total dependência principalmente para aqueles que sempre foram independentes é muito frustrante. 
Questão 3 - O/A Sr(a) acha que precisaria de alguém mais para cuidar do $\operatorname{Sr}(a) ?$

Objetivo: Reconhecer o julgamento que o idoso faz do cuidado que lhe é dispensado e do cuidador familiar.

Foram encontradas 10 categorias/representações nos discursos:

A - Não, a minha família também cuida de mim;

B - Ela é muito eficiente e me atende em tudo o que preciso;

C - Não precisa, eu ainda sou independente para me cuidar;

D - Não precisa, pois também tenho empregada;

E - Eu só tenho ele para cuidar de mim;

F - Só teria a ajuda de Deus;

G - Precisaria, pois sou dependente e não dão conta sozinhos;

H - Não precisa, pois é obrigação de filho;

I - Não precisa porque há uma troca, uma retribuição do cuidado;

J - Não precisa porque conto com a ajuda de amigos e do Centro de Saúde. 


\section{CATEGORIA 3A}

\section{DSC 3 - NÃO, A MINHA FAMÍLIA TAMBÉM CUIDA DE MIM}

Critério de inclusão nesta categoria: o reconhecimento do idoso da participação do núcleo familiar como suporte para o seu cuidado.

...Não, não, para cuidar de mim eu acho que não precisa eu tenho também, a minha mulher que cuida de tudo compreende? Ela também ajuda. Ela faz a comida, me dá tudo em ordem, a tempo, isso eu não posso me queixar, porque ela é uma boa dona de casa. Eu tenho três filhas, um filho a minha nora não conto muito, mas eu acho que se precisar ela cuida sim, porque ela cuidou muito da avó dela. Tem a minha neta que também vem (Uma das minhas filhas) vem sempre por aqui, para dar uma mão. Ela é muito boazinha para me cuidar. Daqui a pouco ela vai chegar aqui para almoçar, todo dia ela vem... Bom, aqui eu recebo um tratamento ímpar de todos. Tem, o (meu genro) que é incansável. Durante a minha vida toda eu nunca o vi, digamos assim de mau humor. Sempre com aquele sorriso, sempre pronto para ajudar, sempre pronto para fazer alguma coisa. Então isso aí tudo a gente tem que agradecer a Deus. ...Então eu penso que um pouco com cada um vamos dividir se eu sair daqui eu fico dias numa casa e na outra, posso ficar em todas elas. Eu penso que se fosse (preciso) não estando ela, eu tenho outra filha, que se precisasse, ela também ficaria comigo. Às vezes eu vou lá, quando não tem médico em seguida aqui, eu vou ficar uns tempinhos lá. Eu tenho um quarto lá. A minha cama de casal tem minhas coisas lá. Às vezes, eu passo uns 15 ou 20 dias com ela, depois eu volto para cá. Tem também uma sobrinha no interior que se eu quiser ir para lá, se eu não tivesse eles sempre fala "ah, tio, quando você precisar pode vir aqui que eu cuido de você". Ela é muito boa, ela é professora mais está aposentada. Ela sempre fala... Mas eu estou bem aqui... Ah, também minha irmã se eu precisar ir ao médico ela vai...Vai todo mundo...Só que está precisando é ajuda de, como se diz? De dinheiro que o meu filho e minha filha de vez em quando me ajudam. Se não fosse a minha filha, coitada, a minha nora não pode pagar porque, ela também está doente. Mas se não fosse...eu garanto que ela faria tudo para me ajudar. Isso eu tenho certeza. Então eu acho que outra pessoa não precisa porque ela faz de tudo. Se não fizesse sim, mas ela faz de tudo...(Id.2;Id.3; Id.4; Id.6; Id.7; Id.15;Id.18; Id.20; Id.22; Id.24; Id.28)

Observação: este discurso foi construído com depoimentos de 11 idosos. Seus cuidadores familiares foram: 9 filhas; 1 filho; 1 esposo.

A composição familiar do tipo multigeracional ainda pode ser encontrada como estratégia de cuidado para estes idosos. Notamos pelos depoimentos que eles têm 
consciência disto e dizem que na possível ausência do cuidador familiar principal possui esta rede que certamente lhes assegurará o seu bem-estar.

\section{CATEGORIA 3B}

\section{DSC 3B -É MUITO EFICIENTE E ME ATENDE EM TUDO O QUE PRECISO}

Critério de inclusão nesta categoria: o reconhecimento do idoso de que seu cuidador é o mais competente para a atividade do cuidado.

Não, mais do que ela? Não, não precisaria não. Ela dá conta, a gente se entende nas coisas dela cuidar de mim, então acho que não haveria necessidade de outra pessoa porque eu também não queria... Porque ela sempre cuida. Só ela é a mais capaz... Até de faltar na escola. Ela cuida demais, fica preocupada... Eu me sinto bem assim, cuidada por ela. Porque ela é muito boazinha para mim... Ah, por exemplo, se eu preciso ir lá ao Centro de Saúde, ela me leva, me ajuda. Se eu pedir para me levar no supermercado ela me leva. Porque é uma boa filha está ajudando bem, está desempenhando bem a função dela. Não precisa de outra pessoa ela faz tudo. Faz o almoço, o jantar, prepara o remédio para a mãe, me dá insulina. Quando ela faz festa na casa dela, Natal, seja o que for, ela leva... Às vezes ela nos leva para passear. Ela cuida direitinho assume a responsabilidade dela e da nossa. Podendo fazer as coisas para mim ela faz. Faz um bolo vem fazer em casa. Precisa de um remédio, precisa de uma água, precisa de qualquer coisa, ela vai entra e dá. Como ela trabalha aqui dentro, é fácil dela cuidar. Ela é a minha mão direita aqui, compreende como que é? Não precisaria de outra pessoa está muito bom. Do jeito que está, está muito bom. E tenho mais liberdade com a pessoa de casa do que com pessoa de fora para falar e para fazer as coisas também. E para fazer as coisas é que é, porque muitas vezes mexe com dinheiro, com uma coisa e outra, compreende, então tem mais confiança. Outra pessoa para cuidar de mim não tem precisão não, por enquanto não. A gente ta remando enquanto ela está agüentando. A hora que ela não agüentar mais tem que dar um jeito. Mas ela ia ficar magoada.... Nem pensar de dizer, eu vou por outra pessoa... (Então) ela está auto, super suficiente. Tudo o que nós precisamos ela faz. Ela é muito boa filha, muito boa, não posso falar nada dela tudo o que eu fizer por ela é pouco. Eu ainda falo todo dia para ela "obrigada, Deus te abençoe, você vai conseguir tudo na vida pela caridade que você está fazendo..." (Id.1; Id.2; Id.11; Id.15; Id.16; Id.19; Id.20; Id.21; Id.28;Id.29, Id.30; Id.31) 
Observação: este discurso foi construído com depoimentos de 12 idosos. Seus cuidadores familiares foram: 7 filhas, 2 filhos, 1 esposa e 2 maridos.

Para estes idosos, o cuidado dispensado é de muita dedicação e de muita confiança. O julgamento que fazem do cuidado e dos seus cuidadores baseia-se na proximidade, nos laços familiares, na disponibilidade e no entendimento que este cuidadores têm para a função que desempenham.

\section{CATEGORIA 3C}

\section{DSC 3C - NÃO PRECISA, EU AINDA SOU INDEPENDENTE PARA ME CUIDAR}

Critério de inclusão nesta categoria: reconhecimento dos idosos de que a realização das Atividades de Vida Diária, AVD, é de suma importância para sua individualidade, independência e sua vida.

...Não, não precisaria por enquanto não porque eu não dou muito trabalho para ela, não dou não. Eu estou cuidando bem de mim estou fazendo tudo para ficar independente dela também, sabe? Porque agora eu já estou começando a andar com mais firmeza, mesmo que seja com bengala, andador já dá para eu fazer as coisas. Vou ao banheiro, tomo o meu banho, lavo direitinho a cabeça, me troco sozinha arrumo a minha cama, desço a escada sozinha. Eu sento naquela cadeira ali e na hora da comida, ela dá comida certa para mim... Eu estou fazendo as coisas ainda sozinha. Já estou ficando independente. Eu tenho vontade de lavar as minhas roupas, passar. Então por enquanto eu acho que no momento eu não estou precisando assim de ajuda eu faço tudo. Não dou trabalho. Agora eu não sei mais para frente como que vai ser... Só se a pessoa não pudesse mais fazer nada estivesse na cama. Eu graças a Deus não estou. Então não precisa mais ninguém. Graças a Deus tem ela que é suficiente que me ajuda, e dá conta do recado. A minha vida é muito parada, muito sem novidade. Eu acho que a gente devia morrer mais cedo, não devia viver tanto. Porque depois que você chega a uns 80 assim, já começa.... Eu estava muito bem até 80, 89 anos... Eu viajava ia para a casa do meu sobrinho, ficava lá dias e voltava. E agora, estou fechada aqui dentro, inutilizada. O que me distrai é a televisão e a leitura. Eu leio jornal de ponta a ponta, leio até anúncio. Eu gosto de política também. A única coisa que eu queria era poder andar outra vez e ter minha atividade, de ir à igreja, poder sair, pegar um ônibus. Agora eu não posso nem subir num ônibus. Nem com ajuda não dá. A perna não dá. É duro, viu?...(Id.1; Id.4; Id.9; Id.12; Id.14; Id.18; Id.23; Id.26; Id.27) 
Observação: este discurso foi construído com depoimentos de 9 idosas. Seus cuidadores familiares foram: 7 filhas, 1 filho e 1 nora. Podemos observar neste discurso quanto a independência nas Atividades de Vida Diária são importantes para os idosos, e quanto ficam apreensivos com a possibilidade da perda desta capacidade. O fato de possuírem um cuidador lhes assegura um conforto e segurança. Outro fator interessante de notar é que apesar da idade avançada estes idosos não mostram expectativa de morte iminente.

\section{CATEGORIA 3D}

\section{DSC 3D - NÃO PRECISA, POIS TAMBÉM TENHO EMPREGADA}

Critério de inclusão nesta categoria: a comprovação do idoso de que a presença de uma empregada ajuda muito o cuidador familiar, que por sua vez fica com a função de coordenador do cuidado.

Por enquanto não porque eu tenho (a minha empregada) que cuida muito bem de mim e é muito atenciosa em tudo...me ajuda a limpar a casa, a lavar, a passar porque sozinha eu não faço as coisas. Por exemplo, eu tomo banho sozinha, eu faço a comida, algum servicinho assim, eu faço, mas tudo, tudo, eu não posso fazer. Eu gosto de ficar na minha casa, gosto de sair, gosto de fazer as minhas compras, então isso eu gosto. E quando é assim, eu quero uma pessoa para ir junto comigo, não é verdade? Porque como eu estou desse jeito eu não posso sair sozinha. Agora, se por um acaso, Deus o livre, que ela não venha, aí o meu filho precisa perder dia de serviço. Mas até agora ele nunca perdeu dia de serviço, porque ele trabalha até de domingo. Trabalha de segunda a segunda. Mas eu estou muito bem. E depois, lá, ele telefona de vez em quando e diz "como é que está a minha mãe, como é que vocês estão aí, o que está acontecendo aí?" E tudo isso. Ele é muito bom pra mim. Ele arruma a minha cama... Ele faz tudo. Ele é um ótimo filho graças a Deus ele é muito bom. Graças a Deus não precisa de mais ninguém. Agora eu quero destacar também o carinho dela (empregada). Ela está sempre pronta, digamos, a me atender naquilo que eu preciso. Parece até que a gente tem assim uma linguagem do pensamento e quando eu penso ela já está lá pronta para atender. Então tudo isso são valores que a gente não pode esquecer. Eu estou no céu, tanto por ela como por ele, pelos dois. Eles me cuidam muito bem, e prestam muita atenção comigo e são muito atenciosos todos os dois, graças a Deus. E aí não precisou ele me pôr no asilo... (Id.8; Id.10; Id.17; Id.24) 
Observação: este discurso foi construído com depoimentos de 4 idosos. Seus cuidadores familiares foram: 2 filhas, 1 filho e 1 neta.

Pela essência do discurso podemos observar que o cuidador familiar, responsável pelo idoso, necessita da ajuda de outras pessoas, em especial da empregada doméstica, que pela função de estar no domicílio é de grande valia para o auxílio do cuidado a esse idoso. Atualmente isto vem ocorrendo com muita freqüência nos lares brasileiros que dispõem de condições financeiras para pagar este tipo de profissional, favorecendo desta forma a permanência do idoso na família.

\section{CATEGORIA 3E}

\section{DSC 3E - EU SÓ TENHO ELE PARA CUIDAR DE MIM}

Critério de inclusão nesta categoria: reconhecimento pelos idosos de que possuem apenas estes cuidadores para desempenharem a função do cuidado.

Eu acho que ele é suficiente por enquanto ele está com a cabeça boa, está com o disco bom eu não preciso de ninguém mais não porque eu não tenho ninguém mais, só ele. Então por isso que eu não gosto nem de pensar como será sem ele. Porque se não fosse ele se não tivesse ele. Só se eu fosse para um asilo... Eu acho que dependendo das minhas condições eu estaria num canto aí qualquer desses que botam a pessoa de lado e deixam ela lá... Mas ele não me deixa... Porque os meus filhos têm mais dificuldades, um que mora longe, outro que mora aqui pegado mais tem muitas atividades, tem 3 filhos pequenininhos, tem um nenê que nasceu agora, tem 2 meses. Então seria muito difícil deles me ajudarem... Até às consultas ele vai comigo. Ele fica naquelas filas do HC para pegar remédio para mim, ele tem que ir a pé até lá. Então ele é muito especial nesse assunto. Agora se não tivesse ele, eu não sei o que seria de mim. Eu tinha uma sobrinha, que morreu, faz 1 ano e pouco, ela me adorava. Aquela nossa senhora. Eu podia contar também... Ela era outra pessoa boa. Agora eu estou bem depois eu não sei....Se um dia não tiver mais ele ou se eu for antes...Mas ele não vai me deixar na mão. Não vai não, eu acho que não... O sonho da minha vida era ter uma família e eu consegui. Ter uma família, os filhos... Ele é muito especial para mim se eu não tivesse casado com ele, eu ia querer casar com ele, a vida toda... Eu ia querer casar com ele...(Id.3; Id.5; Id.22; Id.25; Id.26) 
Observação: este discurso foi construído com depoimentos de 5 idosos. Seus cuidadores familiares foram: 4 filhas ( 2 filhas adotivas) e 1 esposo.

$\mathrm{O}$ forte desta representação é a importância deste cuidador para o idoso, porque sem ele a permanência na família seria praticamente impossível. O sujeito, esposo, escolhido para dar "voz" a esta representação, foi proposital para expressar o significado do cuidado a esses sujeitos com necessidades no seu cotidiano.

O que percebemos no nosso cotidiano de profissionais que trabalham com os idosos é que quando o idoso fragilizado possui um cônjuge sua permanência na família fica assegurada porque ele assume o cuidado. A morte do cônjuge é um risco para o idoso que permanece vivo, ficando o cuidado deste a cargo dos filhos, que muitas vezes não estão disponíveis para esse trabalho.

\section{CATEGORIA 3F}

DSC 3F - SÓ TERIA A AJUDA DE DEUS

Critério de inclusão nesta categoria: constatação dos idosos que na ausência do cuidador somente teriam a ajuda divina.

Só ela mesmo e Deus para ajudar. Porque eu não sei o dia de amanhã não é verdade? O dia de amanhã é um dia difícil que a gente não sabe... Porque eu espero em Deus que não. Mas eu não sei te dizer nem sim, nem não. Por enquanto não... Agora, esperando em Deus o que ele há de fazer comigo, na minha idade. Peço que me dê saúde, que me dê força até o fim da vida. Meu Jesus, meu Deus, Espírito Santo, eu costumo dizer... Já não posso ir para a rua, fazer compras, nada disso. E já não saio sozinha na rua. Acho que eu não tenho mais, não espero mais nada. Eu espero que Ele me dê saúde, que Ele está me dando, pouquinha, mas hoje eu caio, mas amanhã eu levanto, vou para o médico hoje e amanhã eu já estou melhor. Estou bem, sabe, graças a Deus...(Id.5; Id.9; Id.10) 
Observação: este discurso foi construído com depoimentos de 3 idosas. Seus cuidadores familiares foram todas as filhas.

É um discurso carregado de emoção e de apego ao sobrenatural como único meio de amparo nas suas necessidades, na ausência de seu cuidador. Com este depoimento podemos observar quão importante é este sujeito no cuidado do idoso.

\section{CATEGORIA 3G}

\section{DSC 3G - PRECISARIA, POIS SOU DEPENDENTE E NÃO DÃO CONTA SOZINHOS}

Critério de inclusão na categoria: percepção do idoso da sua situação de grande fragilidade e da necessidade de mais de uma pessoa para ajudá-lo no seu cotidiano.

Ah, sim precisa sim, porque ela não dá conta .Como eu estou doente aí sim, precisaria. Eu tenho uma cuidadora para noite, e uma para de dia para poder me ajudar, me levar para o banheiro, me levantar da cadeira, me sentar na cama, me deitar, me virar, porque eu não tenho condições, meu corpo, meu braço doem. Eu não tenho condições de me virar sozinha. Com esse remedinho, tem hora que eu tento me virar. Apesar de toda dificuldade eu estou me movimentando, procurando me virar. Às vezes eu levanto sozinha de uma cadeira com força de vontade. Eu tenho muita força de vontade. (Então) é muita coisa para uma pessoa só fazer. A minha filha orienta, supervisiona a minha vida, o meu físico, a minha saúde, os meus mal estar e tudo, mas não dá conta sozinha. Mas também ela não anda com muita saúde. E está sem força, o pior de tudo é isso, ela está sem força... Mas tem uma força de vontade tremenda. E me cuida, viu? Ela não descuida de mim, não. Muito nervosa, às vezes, meio bravinha, aí eu brigo com ela também... Quando está um pouquinho de mau humor, eu também reajo... É por isso que eu queria ficar independente. A coisa mais triste do mundo é a gente ter que pedir para os outros ajudar a gente quando a gente não pode. E é duro, não é fácil. Eu sei que a gente dá trabalho. Eu sei, eu tenho consciência, eu não sou boba. Eu sei do que acontece na vida real. Eu tenho uma experiência de vida muito grande. E a gente sabe definir de tudo na vida... (Id.11; Id.13) 
Observação: este discurso foi construído com depoimentos de dois idosos. Seus cuidadores familiares foram: 1 filha e 1 esposo.

Podemos observar que este discurso é o oposto do discurso: "Não precisa, eu ainda sou independente para me cuidar." O que reiteramos é que a perda para as AVDs é muito difícil para o idoso e também para o cuidador, que na maioria das vezes não dá conta sozinho do cuidado. Esses idosos dependentes exigem do cuidador um esforço físico e mental muito grande.

\section{CATEGORIA 3H}

DSC 3H - NÃO PRECISA, POIS É OBRIGAÇÃO DE FILHO

Critério de inclusão na categoria: os idosos não consideram outra pessoa para cuidar deles, a não ser os filhos.

...Eu acho que não. A gente já está com tanta idade... Não vai amolar os outros. Eu já estou com bastante idade. ...É a tua obrigação porque é a tua mãe, mas muita gente tem como obrigação e não por amor...(Id.16; Id.22)

Observação: este discurso foi construído com depoimentos de 2 idosos. Seus cuidadores familiares foram: 1 filha e 1 filho.

Para estes idosos o fato de serem pais obrigam os filhos a cuidarem deles na velhice. $\mathrm{O}$ interessante é que reconhecem também que muitos filhos cuidam por obrigação e para não serem criticados pela sociedade e por outros familiares. Esta situação de cuidado gera muito conflito e desgaste para ambos e muitas vezes o maior prejudicado é o idoso que corre sérios riscos de ser maltratado pelos cuidadores. 


\section{CATEGORIA 3I}

\section{DSC 3I - NÃO PRECISA, POIS HÁ UMA TROCA, UMA RETRIBUIÇÃO DO CUIDADO}

Critério de inclusão nesta categoria: reconhecimento do idoso de que a cumplicidade, a força do amor e a troca de cuidados favorecem a retribuição de ambas as partes.

Nossa ela faz com amor, primeiro ela me dá banho, me hidrata, me penteia, faz as minhas unhas...do pé, unha da mão. Ainda eu falo:"ai, como eu estou linda... Vamos descer um pouco e tomar sol? Precisa todo mundo ver como eu estou bonita... Olha como você me deixou, passou perfume, me penteou, tudo..." Depois ela vai tomar banho. Aí eu falo para ela: "Deixa eu ver se você está bem hidratada, passa creme nas pernas, nos braços, no rosto... Deita aqui que eu faço a maquiagem em você. Ela deita e até dorme, e eu passo os cremes...arrumo o rosto dela... E quando ela casou morávamos nós duas aqui aí eu falei para ela, venha morar aqui que você economiza o aluguel. A casa é grande demais para mim... Então ela veio morar comigo... Ia tudo muito bem, até que os meninos chegaram numa certa idade de 7, 8 anos, e o marido dela arrumou a mala e foi embora... Se não fosse eu...Era uma ocasião que eu estava com bastante dinheiro e eu ajudei a criar(os meninos)... Continuamos aqui nós quatro...(Então) é assim... É maravilhoso...(Id.16; Id.26)

Observação: este discurso foi construído com depoimentos de 2 idosas. Seus cuidadores familiares foram 2 filhas, sendo uma adotiva. Esta representação social é muito referendada nos trabalhos desenvolvidos por pesquisadores do envelhecimento, principalmente aqueles que diretamente retratam os cuidadores e a sua relação com os idosos. 


\section{CATEGORIA 3J}

\section{DSC 3J - NÃO PRECISA, POIS CONTO COM A AJUDA DE AMIGOS E DO CENTRO DE SAÚDE}

Critério de inclusão nesta categoria: a constatação do idoso da importância do suporte da rede social auxiliando o cuidador na sua tarefa de cuidar, e favorecendo desta forma a permanência do idoso junto à família. Esta rede de suporte é motivo de autonomia e proteção para o idoso.

Eu não precisei ser internada porque eu achei muita gente boa, graças a Deus, que me ajudou e me protegeu... Os primeiros meses foi a assistente social quem pagou a menina que veio para cá... E eu fiquei muito bem. Depois, eu tinha muita visita... A minha amiga japonesa que ficou comigo uma semana... Ela vinha de manhã e ficava até a uma hora, me dava o almoço, almoçava e ficava comigo. Depois vinha a outra a uma hora e saía as seis horas... Graças a Deus eu nunca fiquei sozinha... (Id.8)

Observação: podemos observar que este discurso foi construído com o depoimento de uma idosa. Esta representação social aparece tímida neste grupo de idosos, talvez pelo fato de termos pouca experiência de nossas comunidades no amparo e na construção de uma rede de suporte social para os grupos mais vulneráveis de nossa sociedade. Temos muito ainda que avançar neste quesito para podermos proteger nossos cidadãos mais necessitados. 


\subsection{ANCORAGENS DOS DISCURSOS}

Foram encontradas 7 ancoragens nas 3 questões analisadas:

A - Ajuda mútua entre pais e filhos - Cuidado recíproco;

B - Filha cuida da família, da casa e dos pais;

C - Os filhos homens não cuidam bem dos pais;

D - A família é que deve cuidar;

E - A nora não cuida como a filha;

F - Asilo é para idosos pobres e casa de repouso é para quem pode pagar;

G - Para a filha cabe o serviço da casa e do cuidado, e para o filho, o cuidado das finanças.

\section{ANCORAGEM A}

AJUDA MÚTUA ENTRE PAIS E FILHOS - CUIDADO É RECÍPROCO

...Quando eu não posso fazer ela faz, quando ela não pode fazer, eu faço para ela...é assim...tem que ser assim mesmo... a mãe com o filho e o filho com a mãe. Tem que ser assim mesmo... (Id. 1)

\section{ANCORAGEM B}

\section{FILHA CUIDA DA FAMÍLIA, DA CASA E DOS PAIS}

É a filha, então desde sempre, por estar mais perto, tem que cuidar mais da gente. É a família da gente... ela é a responsável do serviço da casa... vai tudo na mão dela. Ela sabe como vai fazer, como há de fazer... (Id 20) 


\section{ANCORAGEM C}

\section{OS FILHOS HOMENS NÃO CUIDAM BEM DOS PAIS}

...Porque os outros dois filhos, um está trabalhando em Santos, o outro trabalha também, e outra, são homens, não vai ficar cuidando da mãe... (Id. 16)

\section{ANCORAGEM D \\ A FAMÍLIA É QUE DEVE CUIDAR}

...Ah eu não sei o que seria de mim e do (meu marido) porque a (minha filha) trabalha, e a gente não tem aqui ninguém assim... que seja... família perto... (Id. 19).

\section{ANCORAGEM E \\ NORA NÃO CUIDA COMO FILHA}

...Olha, para dizer a verdade, para ir para a casa dos meus filhos eu acho que não. Porque nora é diferente de filho, de filha. Acho que não tem o que falar... (Id. 27)

\section{ANCORAGEM F \\ ASILO É PARA IDOSOS POBRES E CASA DE REPOUSO É PARA QUEM PODE PAGAR}

...Só se eu fosse para uma casa de...não digo asilo porque asilo é meio pesado... Mas para uma casa de...como é que a gente fala? ...Uma casa de idosos... Que eu pagasse para ficar nessa casa. Não assim como um asilo... que fica lá, um idoso que não tem... que não tem condições de pagar... (Id. 27). 


\section{ANCORAGEM G \\ PARA A MULHER CABE O SERVIÇO DA CASA E DO CUIDADO, E PARA O HOMEM, O CUIDADO DAS FINANÇAS}

...eu tenho a minha mulher que me cuida também... Ela também ajuda. Ela faz a comida, me dá tudo em ordem, a tempo. Isso eu não posso me queixar, porque ela é uma boa dona de casa...Ele (filho) também me ajuda faz muitas coisas... Ele é a minha mão direita aqui...Vou para cá, faço os meus recibos de inquilinos que eu tenho... E tenho mais liberdade com a pessoa de casa do que com pessoa de fora... Para falar e para fazer as coisas também... porque muitas vezes mexe com dinheiro, com uma coisa e outra...então tem mais confiança...(Id. 2). 


\section{DISCUSSÃO}

O propósito deste estudo foi descrever e analisar as representações sociais de uma parcela de idosos com pequenas incapacidades e fragilidades decorrentes do envelhecimento, e que por apresentarem estas características precisavam de um cuidador familiar no auxílio de suas necessidades de vida diária.

CAMARANO e PASINATO (2004) relatam: "Através do perfil sociodemográfico da população idosa...uma parcela não desprezível tem dificuldades em ouvir, enxergar, subir escadas, lidar com as AVDs... é este segmento que demanda maiores cuidados, que recaem quase sempre sobre a família. Grande parte destes idosos mora em casas de parentes..." (p. 11).

A maioria dos idosos entrevistados era composta por mulheres, o que está de acordo com o que expõem os estudiosos, que admitem ser o envelhecimento um fenômeno feminino.

CAMARANO et al. (2004) afirmam que “...o envelhecimento é também uma questão de gênero; considerando a população idosa como um todo, observa-se que 55\% dela são formados por mulheres... A proporção do contingente feminino é mais expressiva quanto mais idoso for o segmento..." (p. 29). Esta afirmação também foi observada nos idosos da pesquisa, pois a maior concentração deles estava situada na faixa etária de 76 - 95 anos. Cabe-nos esclarecer que a variável faixa etária foi intencional,uma vez que as incapacidades para Atividades de Vida Diária (AVDs) e Atividades Instrumentais de Vida Diária (AIVDs) são mais comuns nos idosos mais velhos, vale dizer, acima de 75 anos.

As idades avançadas somadas às fragilidades apresentadas eram componentes que determinavam obrigatoriamente a presença do cuidador que, no caso, eram os familiares. Quanto às fragilidades, destacamos que 25 idosos, ou seja, 80,6\%, mostraram ser capazes de ter o controle de esfíncteres, 29 idosos, ou 93,5\%, possuíam perdas para as AIVDs como: dificuldades para cozinhar, executar trabalhos domésticos, fazer compras, telefonar, administrar as próprias finanças e tomar remédios receitados 
sozinhos; 19 idosos, ou 61\%, mostraram-se capazes de se locomover dentro e fora de casa. Para as atividades de autocuidado, aproximadamente metade dos idosos, ou seja, $51,6 \%$, conseguiam executar as atividades de banho, alimentação, e eliminações sozinhos, e 48,4\% apresentavam fragilidade, variando de incapacidade mínima a totalmente dependente para a sua realização. Quanto às quedas, 29\% dos idosos referiram terem ocorrido nos últimos 12 meses.

Todos os idosos possuíam recursos financeiros, e em geral sua renda era proveniente de aposentadoria e pensão. Percebemos durante a pesquisa de campo que os rendimentos dos idosos eram um fator decisivo para eles porque favoreciam uma melhor condição econômica para toda a família, que em alguns casos ( 8 famílias) eram famílias estendidas, ou seja, com a presença de netos e bisnetos.

De fato, os benefícios da Seguridade Social nos arranjos familiares onde há a presença dos idosos são de suma importância para a composição da renda desta família (CAMARANO; KANSO; MELLO, 2004). Na fala de SAAD 2004 “.... a casa própria do idoso ou mesmo seus diminutos rendimentos de pensão e aposentadoria estariam se transformando em valiosos senão únicos proventos familiares...” (p. 170).

Alguns idosos, além da aposentadoria ou pensão, também possuíam outras fontes para completar suas despesas como: poupança, receber ajuda em dinheiro ou espécie, aluguel, benefício assistencial. As viúvas eram as que usufruíam da pensão. CAMARANO et al. (2004) referem também que "quase 1/3 do orçamento das famílias com idosos são as mulheres viúvas que recebem pensão por morte dos maridos..." (p.159). Embora possuíssem recursos financeiros próprios, o aparecimento da fragilidade repercutindo no seu cotidiano obrigava-os a aceitar cuidados mais diretos de algum membro da família. Ao aceitar esta situação deixavam de ser responsáveis pelo domicílio, passando para a posição de colaboradores com necessidade de cuidados.

Quanto ao tipo de parentesco que mantinham com seus cuidadores familiares, a grande maioria destes era do sexo feminino, geralmente filhas seguidas dos cônjuges, o que confirma as pesquisas nesta área. Pudemos identificar também cuidadores do sexo masculino, com números percentuais iguais entre filhos e esposos como cuidadores 
principais. Isto pode estar relacionado ao fato de que cada vez mais os filhos permanecem morando com seus pais por necessidades econômicas.

\subsection{ALGUMAS CONSIDERAÇÕES PRELIMINARES}

Antes de fazermos uma análise mais detalhada das representações encontradas parece-nos necessário explicar a importância deste trabalho e como foi construído o raciocínio para a apresentação da discussão. O principal objetivo foi a obtenção da fala através das representações de idosos em idades avançadas que possuíam um membro familiar para o auxílio de seu cotidiano. O desejo de mostrar o que pensavam, como percebiam esse cuidado e o que representava esse elemento familiar em sua vida mobilizou a autora a trilhar os caminhos da pesquisa qualitativa e usar a teoria de representação social.

Seria possível enumerar momentos julgados importantes durante todo este processo: o período de contato com os idosos e as entrevistas realizadas no domicílio; a leitura das falas e a confecção dos discursos, mantendo fidedignas suas observações sem interferir no seu conteúdo; e redigir a discussão do modo mais claro possível, mostrando os resultados e ponderando junto à literatura especializada com vistas a dar mais visibilidade e legitimidade aos discursos. Durante este último momento consideramos que o entendimento das representações e da discussão, para sua mais adequada compreensão, deveria ser organizado em dois grandes blocos. $\mathrm{O}$ primeiro mostrou os sentimentos que emergiram dessa relação de cuidados, que era o objetivo da primeira questão. Vale lembrar que duas representações encontradas na primeira questão e intituladas Cuidador Competente/Bom Tarefeiro e Objeto Fácil para o Cuidado, após análise e discussão foram anexadas no segundo bloco, considerando que se tratava de representações que expressavam o julgamento, por parte dos idosos, do cuidador e do cuidado dispensado. Os grandes temas que emergiram no segundo bloco, que se referiam ao julgamento dos idosos, foram: a Competência do Cuidador (Cuidador Competente, Eficiente, Bom Tarefeiro); a Ausência de Outro Elemento para Exercer o 
Cuidado (Só tenho ele para cuidar de mim. Não tenho mais ninguém); a Parcial Independência do Idoso (Sou objeto fácil do cuidado, pois sou independente), e a Enumeração de Outras Alternativas caso o cuidador não pudesse mais executar o cuidado, como: (Família, Casa de Repouso, Outro Cuidador, Empregada Doméstica, Deus, Morar Sozinha, Centro de Saúde e Amigos, Preciso dele pois sou dependente).

Será necessário mencionar que houve representações que foram possíveis de ser encontradas em duas e até três questões formuladas e também nas ancoragens, que apresentamos separadamente no item Resultados, de acordo com a ordem de aparecimento, mas que nesta Discussão foram unidas com o intuito de ressaltar a importância destas representações. No $1^{\circ}$ bloco a representação que denominamos Obrigação/Retribuição apareceu nas três questões formuladas. Os DSCs (1E; 2E; 3I; 3H) foram apresentados e discutidos conjuntamente para melhor entendimento da representação. No segundo bloco mantivemos o mesmo raciocínio nas representações: Cuidador Competente, Eficiente, Bom Tarefeiro, com os DSCs (1D;2F; 3B); na representação Sou objeto Fácil do Cuidado pois sou Independente com os DSCs (1B; 3C); na representação Só Tenho Ele para Cuidar de Mim, Não Tenho Mais Ninguém, Só Ele, com os DSCs (2A; 3E). Na representação Tenho Minha Família, com os DSCs (1I; 2D; 3A; ancoragem B); na representação Teria Casa de Repouso, nos DSCs (2B; ancoragem F); na representação Sou Dependente, Preciso Dele, nos DSCs (2I; 3G); na representação Deus Toma Conta, nos DSCs (2G; 3F).

Quanto às representações encontradas nos discursos desses idosos, julgamos que são elementos importantes para os pesquisadores do envelhecimento porque nos remetem ao universo pessoal de cada um deles, mostrando através de sua fala seus temores, anseios, esperanças, crenças, e acima de tudo a essência do cuidado que recebem de seus cuidadores. 


\subsection{DISCUSSÃO PROPRIAMENTE DITA}

As três questões elaboradas para a obtenção dos discursos possibilitaram o desencadeamento de idéias e depoimentos que possuíam uma lógica de raciocínio e uma clareza muitas vezes surpreendente.

Ao analisarmos os discursos dos idosos na dimensão dos sentimentos notamos que foram carregados de emoção, de palavras de apoio, de carinho e de dedicação, quando mencionaram as qualidades do cuidador. Presenciamos, como profissionais, com freqüência, na relação desta díade que atende esta população, uma relação tumultuada e cheia de dúvidas e sensações de cansaço e desânimo de ambas as partes.

De fato, as relações humanas são permeadas de sentimentos contraditórios e divergentes no momento que experimentam situações de extremo limite da vontade. Quando somos obrigados a deixar nossa vida para viver a vida do outro, e fazer para o outro aquilo que não é mais capaz de fazer por si só, experimentamos o desgaste de ter que atendê-lo em suas necessidades. As representações quanto aos sentimentos que pudemos depreender dos discursos foram referentes: ao afeto, à vocação para o cuidado, à solidão, obrigação/retribuição, desgaste/tensão, troca de papéis.

$\mathrm{O}$ afeto foi um componente fundamental mencionado pelos idosos no seu cotidiano de relações com o seu cuidador. Para eles é o tempero essencial e imprescindível para o cuidado. Com efeito, os idosos atribuem ao cuidado executado por seus cuidadores um sentimento de afeto, dedicação, preocupação, atenção, e muitas vezes de sacrifício.

O discurso que apresentaremos abaixo reforça o que BOFF (1999) estabelece sobre a dimensão do cuidado: "O cuidado somente surge quando a existência de alguém tem importância para mim. Passo então a dedicar-me a ele; dispondo-me a participar de seu destino, de suas buscas, de seus sofrimentos e de seus sucessos, enfim de sua vida" (p. 91). 
Vejamos o discurso:

Boa cuidadora, excelente, maravilhosa. Para falar sobre os cuidados que ela me dispensa, eu tenho que primeiro vencer a emoção, tal é o carinho que ela tem pela minha pessoa e pela minha esposa ela é de uma constância que chega até a comover a gente. Ela é uma filha carinhosa, fica preocupada comigo é até um pouco exagerada. Quando ela me vê assim doente, ela fica desesperada enquanto não leva no médico, não sossega. Eu às vezes estou ruim dos quadris aí ela bate, massageia porque eu sinto dor. E os remédios tudo na hora certa também se eu esqueço ela lembra. Ela me dá banho, me hidrata, para ficar com a pele boa. Se eu acordar a noite, ela olha o que está acontecendo pula da cama na hora e vem cuidar de mim. Tem um cuidado comigo. E a alimentação, precisa de ver como ela cuida. O médico falou que eu comesse uma manga todo dia em jejum, por causa do intestino ela anda o mundo, mas ela acha a manga e traz para mim. E ajuda física, de fazer força, ela não pode, mas assim mesmo ela faz e eu fico muito aflita com isso porque eu sei que eu estou prejudicando a minha filha. ...E também ela não sai de casa sem dizer "mãe, eu vou até ali e já volto". Triste de mim se não tivesse a minha filha estava embaixo do chão... Foi Deus que me deixou ela... para cuidar de mim. Se eu não tivesse ela o que não sofria nesse mundo. Às vezes fico pensando, eu não sei até quando eu vou viver, mas Deus me livre se acaso ela for embora primeiro o que seria de nós dois sem ela? Então eu acho que outra pessoa não ia fazer assim. Acho que enjoa de ficar...Se ela não fosse boa não faria isso. Ela é tudo para mim. Não me falta nada, tudo na minha mão. (Id.4; Id.6; Id 9; Id.13; Id.16; Id.19; Id.21; Id.23; Id.24; Id.26).

Novamente citamos Boff: "Cuidado significa então desvelo, solicitude, diligência, zelo, atenção, bom trato... é um modo de ser onde a pessoa sai de si e centrase no outro com desvelo e solicitude" (idem, p. 91).

Numa análise deste discurso verificamos que o idoso sente-se amparado no cuidado que lhe é dispensado, chegando a citar os obstáculos cotidianos que o cuidador é obrigado a superar no seu dia-a-dia.

O cuidado visto pelos idosos como uma obrigação/retribuição por parte dos cuidadores é racionalizado na medida em que os idosos justificam serem merecedores de cuidados, porquanto o fizeram quando podiam e quando foi necessário e solicitado. Reconhecem que é uma tarefa difícil e agradecem; reconhecem que o cuidador é “espetacular" e atencioso, mas justificam que é o que está mais próximo, responsável pela casa e por eles, e mais ainda, que eles estão retribuindo o que receberam anteriormente; portanto, têm obrigação de fazê-lo. 
Esta representação é freqüentemente referida em trabalhos com cuidadores. No discurso comprovamos que o cuidado é uma conseqüência natural da vida, quando é necessário para uma pessoa mais fragilizada. Há transmissão de valores, de condutas, de atitudes que se mantêm durante todo o processo de cuidados. Como pondera GOLDANI, 2004 “...os sentimentos de obrigação que atravessam as gerações são influenciados não só pelas experiências únicas dos indivíduos de uma família particular, mas também por circunstâncias históricas específicas” (p. 229). O discurso a seguir mostra a justificativa e o caráter natural da obrigação/retribuição deste cuidado:

...Boa cuidadora é demais ela cuida muito bem é muito atenciosa é espetacular é fora de série ela vale por 10. Se eu tivesse 10 filhos, eu acho que não faziam o que ela faz. Tudo o que eu quero ela me faz é a família da gente...é a filha, então desde sempre, por estar mais perto, tem que cuidar mais da gente é a responsável da casa, o serviço de casa, vai tudo na mão dela ela sabe como vai fazer. Na verdade, ela tem muito cuidado comigo porque eu criei ela quando ela tinha uns dois ou três anos eu ia almoçar em casa ela me agarrava e não largava, chorava, queria um brinquedo. Por isso que hoje ela me recompensa. Eu ia na esquina e comprava um brinquedinho, qualquer coisinha, dava para ela, dava uma volta no quarteirão e ela dormia e eu ia trabalhar. Era assim... Todo domingo eu ia com ela no Ibirapuera, soltava aviãozinho, ela ficava olhando. E eu cresci com ela até moça, passeando e viajando muito com ela. Eu também cuidei muito dos filhos dela, cuidei toda a vida ...quando ela casou morávamos nós duas aqui aí eu falei para ela, venha morar aqui que você economiza o aluguel. A casa é grande demais para mim... Então ela veio morar comigo... Ia tudo muito bem, até que os meninos chegaram numa certa idade de 7, 8 anos,e o marido dela arrumou a mala e foi embora... Se não fosse eu ...Era uma ocasião que eu estava com bastante dinheiro e eu ajudei a criar(os meninos)... Ela lecionava e eu que tomava conta das crianças ela ficou doente, ficou internada 9 meses num hospital em Araraquara e não larguei dela. Então tá a prova ai tudo o que ela faz, todo dia traz comida, traz pão, vê se precisa de alguma coisa, me aplica insulina, Nossa ela faz com amor ...me dá banho, me hidrata, me penteia, faz as minhas unhas...do pé, unha da mão...passa perfume, me penteia, tudo. Depois ela vai tomar banho. Aí eu falo para ela: "Deixa eu ver se você está bem hidratada, passa creme nas pernas, nos braços, no rosto... Deita aqui que eu faço a maquiagem em você. Ela deita e até dorme, e eu passo os cremes...arrumo o rosto dela... Ela se preocupa... vai ao supermercado, vai ao Ceasa...mas ela me disse uma vez ..."eu já estou cheio de tomar conta de você." Então eu disse para ela - bom, eu agradeço bastante você tomar conta de mim, paciência, porque eu por mim, eu já fiz para você tantos anos, agora eu deixo você me fazer, não é? Aí ela fica quieta...mas quando eu estou doente, eu tenho tudo o que eu preciso. Eu tenho o carinho dela...tenho os cuidados...(Id.05; Id. 06; Id. 12; Id.16; Id.20; Id.21; Id.26; Id.29) 
O discurso acima é repleto de significado quando os idosos enumeram as justificativas da retribuição do cuidado por uma atitude de ajuda que prestaram ao seu cuidador no passado.

ROSSETTO MAZZA 2002 quando analisou os discursos dos cuidadores, verificou também a obrigação/retribuição que eles sentiam em proporcionar o retorno dos cuidados e "devolver um pouquinho da atenção que ela me deu quando eu era bebê" (p. 77).

Analisando mais profundamente os discursos podemos perceber que a obrigação aparece também com uma conotação mais forte quando os idosos solicitam, e muitas vezes exigem a cobrança do cuidado, principalmente por parte dos filhos. Através dos discursos podemos observar que o fato de os idosos serem pais lhes dá o direito de receberem e obrigarem os filhos a cuidar deles na velhice. Trata-se de uma expectativa de comportamento em relação ao cuidador familiar.

Esta imposição de obrigação pode gerar conflitos que podem desencadear situações difíceis para ambos. Durante o trabalho de campo foi possível constatar o que os demógrafos têm enfatizado sobre os arranjos domiciliares que atualmente o Brasil vem apresentando: a coabitação de idosos e seus filhos, que por terem maior dependência econômica de seus pais retardam sua saída da casa paterna/materna, ou são obrigados a retornar por dificuldades econômicas na situação de dependentes. Estando junto aos pais idosos que apresentam fragilidades, passam a prestar-lhes os cuidados necessários. O discurso a seguir trata da obrigação com o idoso se posicionando no controle da situação com autoritarismo, no relacionamento com seus dependentes:

...Ah, eu brigava fazia um escândalo porque ou tem que me ajudar ou senão pinica....tem que ir embora. Porque eu gosto muito de brigar. Eu gosto das coisas direitas. Não gosto de nada errado. Ou bem ou mal. Se faz por bem, fica por bem, se faz por mal, some da minha frente. Mas ele nunca diz não ele é bonzinho...sempre me ajuda bem. Ainda bem que eu criei ele... A gente já está com tanta idade... Não vai amolar os outros. Eu já estou com bastante idade. ...É a tua obrigação porque é a tua mãe, mas muita gente tem como obrigação e não por amor... Tenho duas irmãs, sobrinhas, tenho tudo. Mas eu acho que a obrigação é do meu filho. Eu tenho meu filho, nem ficaria bem eu ir para a casa dos outros ele estando aqui...(Id.14; Id.16;Id.17; Id.22 Id.26). 
Este tipo de posicionamento na maioria das vezes é o precursor das relações desajustadas e geradoras de maus-tratos. Há a exigência por parte do idoso da retribuição, nem que seja pela força. A relação de cuidado fica prejudicada acentuando aspectos negativos no cuidar/cuidados. Esta relação é influenciada pelas relações de poder, ou seja, a posição de poder que o idoso ocupava anteriormente no contexto familiar. A literatura mostra que nesta situação há a possibilidade do cuidador utilizar-se da relação de cuidados com vistas à retaliação, sendo uma das justificativas encontradas para a prática de violência e maus-tratos.

A tensão $e$ o desgaste são representações muito referidas por todos os pesquisadores de cuidadores, quando mencionam o idoso com necessidade de cuidados. O que concluímos é que quanto maior a dependência do idoso, maiores são o desgaste e a tensão do cuidador, podendo até adoecer caso não seja auxiliado no cuidado (NERI, 1993; WANDERLEY, 1998; VELASQUEZ, 1998; MARQUEZ, 1999; SILVEIRA, 2000; NUNES, 2002, entre outros). Medidas de prevenção do tipo grupos de apoio psicológico, orientações sobre o cuidado, lazer, divisão e escala de tarefas entre os familiares, entre outras são fundamentais para auxiliar o cuidador a prevenir a depressão e agravos de saúde. Ao ouvirmos os idosos podemos verificar que eles têm a percepção desta tensão e deste desgaste, lamentando e muitas vezes aceitando as imposições por parte de seus cuidadores. Convivendo com cuidadores e idosos nos mais diferentes tipos de prejuízo da autonomia e independência, e observando sua relação de cuidados podemos considerar que mesmo com os idosos que não possuem muitas perdas, seus cuidadores são estressados e há neles a presença de desgaste e tensão. Trata-se de uma representação que determina um comportamento-papel: todo cuidador deve sofrer ao cuidar do idoso - o que valoriza os aspectos negativos do cuidado na velhice. É uma representação hegemônica sendo encontrada em diferentes grupos sociais: cuidadores, idosos, profissionais e pesquisadores.

Não é difícil imaginar que o cotidiano do cuidado e da convivência com uma pessoa que depende de nós para atividades das mais variadas causa-nos um sentimento de aprisionamento, de cansaço, de angústia e tristeza, em divergência com sentimentos 
de compaixão, de complacência, de amor, de pena, de remorso. Esta ambivalência de sentimentos, presente no cuidador e percebida pelo idoso, propicia o surgimento de manipulação de ambas as partes prejudicando ainda mais a relação fragilizada. ROSSETTO MAZZA (2002) numa pesquisa com cuidadores de idosos encontrou o seguinte discurso ambivalente: “...eu nem sei explicar, a gente tem que levá, ah! Eu fico assim..., nervosa, mas a maior parte do tempo eu fico contente; tem hora que me enervo mesmo, como eu já falei, no fundo no fundo... o que a gente vai fazer? ... a gente tem dó, pois chega a uma certa idade, ter que colocar no asilo, sabe lá como é tratado. Tem hora que ela ultrapassa os limites...(10)”. A situação de cuidado com idosos fragilizados acontece na interação de ambos e progride a partir das necessidades que o idoso vai apresentando ao longo do processo. Por isso causa tanto estresse e desconforto para o cuidador. O processo é um aprendizado constante para o cuidador porque este tem que executar o cuidado, muitas vezes sem ter conhecimento de como fazer controlar as emoções e o temperamento de quem cuida e controlar suas necessidades pessoais, suas emoções e tensões, que advêm da prática do cuidado.

Então, como agir para encontrar um meio termo entre cuidar da minha pessoa e também do outro? Talvez a resposta esteja no que BOFF (1999) apresenta com simplicidade intrigante: "o cuidado surge quando se encontra a justa medida. Este é o caminho do meio... Por isso o cuidado não convive nem com o excesso nem com a carência. Ele é o ponto ideal de equilíbrio entre um e o outro" (p. 162).

O encontro do ponto ideal é o desafio de idosos e cuidadores no seu cotidiano de cuidados e relações conflitantes. Notamos que ambos os lados possuem diferentes opiniões e modos de ser e enxergar o mundo e suas dificuldades. Mas como se trata de uma relação de desigualdades em que o idoso é o mais fragilizado, a tendência é prevalecer a vontade do cuidador. Como alcançar o equilíbrio e o autocontrole para praticar o cuidado e saber receber o cuidado? Diferentes modos são utilizados por eles, às vezes com sucesso, outras vezes sem, onde as agressões passam a ser o elemento principal da relação, outras vezes a superproteção impedindo que o idoso exerça a sua vontade. 
O que verificamos, de um modo geral, são famílias que se sentem abandonadas e sozinhas para prestar cuidados aos seus membros mais vulneráveis. Quando encontram serviços de saúde e sociais para auxiliá-las no cuidado propriamente dito, no amparo psicológico e de sua saúde, a prestação do cuidado fica mais fácil e menos onerosa tanto para o cuidador quanto para o idoso. O que desejamos mostrar aqui é que o desgaste e a tensão estão presentes em todas as relações humanas; a diferença é que para alguns eles são mais tolerados e menos estressantes do que para outros. Alguns conseguem minimizar melhor os efeitos deletérios do que outros, criando mecanismos de defesa competentes e eficientes para evitar que sucumbam. O discurso a seguir mostra quanto o desgaste e a tensão estão presentes numa relação entre um idoso e sua cuidadora não importando o parentesco que existe entre eles. A "voz" escolhida para mostrar este discurso foi a de um esposo que comenta:

...É uma boa cuidadora, é atenciosa ela cuida bem de mim, só que ela é muito nervosa comigo. Ela acha que eu sou muito teimoso... No restante ela me trata muito bem até que nós vivemos já há 45 anos, só que ela briga muito comigo. Às vezes eu quero falar qualquer coisa assim, ou mesmo quando eu falo de telefonar para os amigos ela acha ruim. Acha ruim, porque não precisa falar. E eu fico triste com isso. De vez em quando ela se exalta, mas passa. Fala que eu sou muito chato (risos). Uma vez ela falou que eu sou chato e eu falei "eu sou chato mais não sou gilete". (risos) ...E vamos vivendo, casalzinho de pombinhos. ...É fogo, é assim as coisas, viu. Até que Deus nos tire do mundo porque nós estamos aqui é uma passagem. Mas ela é uma boa esposa, uma boa cuidadora. Não resta dúvida. (Id. 4; Id.29).

A vocação do cuidador para executar o cuidado é um atributo que a autora observa na sua vivência como enfermeira e prestadora de cuidados. Ter vocação para cuidar de alguém não é para todo cuidador! É necessário ter disposição, doação, respeito, dedicação, e acima de tudo perceber e entender o sofrimento do outro como algo importante, para o qual seriam necessários cuidados e atenção com vistas a tentar encontrar um meio de ajudá-lo a superar e amenizar seu sofrimento. O sentido do termo vocação para o cuidado que usamos para caracterizar esta representação tem o mesmo sentido que BOFF 1999 menciona quando classifica o modo-de-ser-cuidado ao dizer: "Cuidar das coisas implica intimidade, senti-las dentro, acolhê-las, respeitá-las, dar-lhes sossego e repouso. Cuidar é entrar em sintonia com, auscultar-lhe o ritmo e afinar-se 
com ele" (p. 96). Cuidar com este sentido não é um valor inerente a todas as pessoas, mas sim característica individual de cada um.

SANTOS 2003, citando vários autores, atesta que alguns cuidadores familiares de seu trabalho possuíam um perfil característico para o cuidado, ou seja, “já possuíam uma história anterior no exercício do papel de cuidadores (...) “Algumas mulheres até se designavam como sendo cuidadoras da família, ou melhor, tinham uma 'carreira como cuidadoras"” (p. 100).

Os idosos de nosso trabalho também identificaram aqueles cuidadores que sempre estiveram disponíveis para o cuidado. Ouçamos o que falam:

...Ah, ela é uma boa cuidadora é demais é boa mesmo cuida muito bem de mim cuida com carinho, com dedicação, com amor. Sempre foi assim mesmo quando eu morava no interior, ela não morava aqui comigo, mas qualquer coisa que telefonava para ela que eu estava ruim, ela já vinha cuidava de mim e já levava para o médico se preocupava muito comigo. Ela sempre mandava dinheiro para mim, pra ajudar nas despesas tudo. Ela cuida bem de mim mesmo, cuida como deve ser cuidado não posso reclamar e não só para mim, sabe, mas para mim é mais. Então tem toda a confiança de deixar mas ela não gosta que eu reclame... (Id.09; Id.22; Id.25; Id.28).

Em uma relação de cuidados onde há uma das partes mais fragilizada, a tendência é que o outro assuma o controle do cuidado. O diálogo franco e aberto é o veículo propulsor para a harmonia da relação. Quando se trata de idosos e seus cuidadores, juntos eles possibilitam uma interação de cumplicidade e disponibilidade de ambas as partes, uma vez que o idoso precisa abrir mão do controle que possuía sobre a sua vida e transferi-lo para seu cuidador, e este precisa ter a disponibilidade de aceitar substituir e incorporar este novo papel. MARQUES 1999 e ANGELO 2000 advertem sobre a importância de que a inversão de papéis seja algo menos traumático para a dinâmica familiar, porque na maioria das vezes os familiares são chamados para este trabalho, sem outra solução possível. Sentem-se perdidos e com sentimentos conflitantes ante a possibilidade de terem que cuidar daquela pessoa que normalmente foi a que lhe prestou cuidados. ROSSETTO-MAZZA (2002) extraiu dos depoimentos dos cuidadores de sua pesquisa uma interessante similaridade na descrição da inversão de papéis, quando falavam: “...Então eu faço para ela tudo realmente o que uma mãe faz pro seu 
filho, ela considera que eu sou mãe dela, e como eu não tenho filho, nunca tive, para mim ela é minha filha mesmo..." (p.81).

Ouçamos agora o que os nossos idosos falaram:

...Olha, ela é maravilhosa e o que me ajuda também é que nós mantemos sempre um diálogo às vezes sobre certas coisas, que aconteceram, acontecem, então esse bate papo aí também ajuda, digamos, a gente a viver. Sinceramente, ela é ótima para mim ela é assim para mim... já é uma mãe daquelas mães que cuidam dos filhos pode ficar certa, já não é mais filha eu agora sou filha dela e ela agora é a minha mãe. Imagina, ela sabe, ela que me vê remédio. Agora, a gente tem uma hora de briga. Tem horas que eu quero comer alguma coisa e ela diz "...oh mãe, eu sei o que você pode, eu estou tomando conta de você...eu sei o que é bom para você, a senhora reclama tanto que quer ir morar sozinha, eu vou deixar a senhora morar sozinha, a senhora não sabe, $e$ nunca soube, agora depois de 87 anos a senhora vai fazer uma comida para a senhora não faz... "Sua roupa a senhora vai lavar direito para eu ver a senhora bem alvinha como eu gosto assim?...Então sou eu que vai ter que ficar, não adianta a senhora ser teimosa, pode chorar, pode fazer o que quiser é assim mesmo". ...Ela vai comigo comprar as coisas...vestido, por exemplo. Quando chegou lá ela olhou, o que eu olhei também, e ela "eu não sei se a senhora vai gostar dele". Eu vou gostar sim, pode deixar. "Mãe, vem aqui, sai, deixa a moça aí e vem aqui, a senhora vai gostar desse vestido sabe pra que? A senhora fica um dia ou dois, veste ele três, quarto vezes, e depois dá para outra pessoa. Não é assim que a senhora faz?"...Eu falei - não, não é tanto assim, não eu sei muito bem o que falo e o que faço...Então quando eu não posso fazer ela faz, quando ela não pode fazer, eu faço para ela...É assim...tem que ser assim mesmo... A mãe com o filho e o filho com a mãe. Tem que ser assim mesmo... $\quad$ (Id.01; Id.16; Id.24; Id.31).

A última representação referente aos sentimentos foi a solidão que o idoso demonstra sentir quando o cuidador precisa se ausentar, por necessidades de trabalho ou mesmo para ter um pouco de privacidade. A ausência de uma companhia só para estar presente e ou para auxílio nas suas atividades de vida diária é sentida e lamentada de forma comovente e esclarecedora, uma vez que os idosos detalham as atividades cotidianas de autocuidado refletindo quanto sua independência é essencial e valorizada, e quanto é temível a sombra da incapacidade. Na descrição destas atividades cotidianas que realiza sozinho estão o ressentimento e a sensação de solidão que o idoso vivencia todo dia. Este discurso é revelador da necessidade humana de cuidado, sobretudo quando há a consciência da perda gradativa dessas capacidades. 
JOAN ERIKSON 1998 reflete sobre como é a velhice em idade mais avançada "A velhice depois dos oitenta, noventa anos traz consigo novas exigências, reavaliações e dificuldades diárias...” (p. 89). A constatação desta nova realidade, cercada de dúvidas e incertezas quanto ao futuro, propicia a reflexão sobre a finitude mais próxima do que pensávamos quando ainda éramos jovens. A noção consciente do enfraquecimento do corpo e das limitações do envelhecimento propicia o desafio diário na execução das atividades mais rotineiras da vida. Novamente citamos a autora “...mesmo os corpos mais bem cuidados começam a enfraquecer e não funcionam como antes; apesar de todos os esforços para manter a força e o controle, o corpo continua a perder a autonomia...”(p. 89). Traduzindo o que escreveu a autora constatamos que a perda da autonomia desafia nossa auto-estima e a confiança em nós mesmos, ficando vulnerável o nosso ser. A luta para a preservação destas capacidades gera tensão e desespero por parte dos idosos, culminando muitas vezes no aparecimento de depressão e apatia. A necessidade de adaptação é imperiosa embora isto exija muito desgaste de energia. $\mathrm{O}$ discurso a seguir contagia e emociona nesse sentido:

...É minha amiga mas ela vai aonde quer. Ela vai embora e eu fico sozinha. Vai às entrevistas que gosta e eu não obrigo nada. Ela deixa o almoço na mesa eu aqueço. Eu faço tudo. Só não faço esse trabalho pesado, temos faxineira. Eu pago. Eu fico em casa, deito sozinha. Eu acho que estou bem porque tenho noventa e tantos anos e faço tudo sozinha. Hoje, como quase todos os dias, sozinha. Só quero que elas (filhas) estejam em casa porque tenho medo de cair, mas eu entro sozinha no banheiro, tomo banho, me enxugo e vou para o meu quarto, que é logo ali ao lado para me vestir. Vistome, sento ao fundo da minha cama para pôr a calcinha. A calcinha sou eu mesma que cuido, que as lavo, ponho numa bacia com água e um pouco de sabão. Eu não as sujo, porque elas vão por cima da fralda. Eu não uso as fraldas todo tempo, só quando eu faço muito xixi. Eu acho que na minha idade, fazer isso, saber pendurar, pôr no arame... Eu faço muitas coisas para mim. Comida não. Tenho medo de me queimar. Minha mão não é firme. Às vezes eu até digo comigo mesma 'ai como minha mão não presta!' Às vezes deixo cair as coisas, mas quando aqueço a comida e ponho em cima da mesa, numa bandeja, eu tenho todo o cuidado para não deixar cair da mão. E nunca aconteceu. Nunca quebrei nada. Então acho que estou bem neste sentido... Às vezes penso que eu estou bem. (10). 
Na velhice a adaptação à nova realidade de perda da autonomia e capacidades faz com que "a pessoa reúna todas as experiências prévias e se apóie nelas, mantendo-se consciente e criativa com uma nova dignidade" (idem, 1998, p. xii).

As representações que apresentaremos a seguir possuem interessantes significados quando representam o julgamento do cuidador e do cuidado que os idosos recebem de seus familiares. Emergiram dos discursos representações que são atributos exclusivos do cuidador quando envolvem a competência, eficiência do cuidador, pois é bom tarefeiro e atende em tudo que precisa. São atributos deles próprios quando mencionam: Sou objeto fácil do cuidado pois sou independente; em contraposição, o reconhecimento da dependência que têm do cuidador quando dizem: Sou dependente, preciso dele; a importância fundamental deste cuidador, quando podem contar somente com ele na representação: Só tenho ele para cuidar de mim. Não tenho mais ninguém, só ele, e quando, apesar de ter um cuidador, teria outras alternativas de cuidado no caso da impossibilidade de ele exercer a função, como: contar com a família como provedora de auxílio, procurar outro cuidador, ir para instituição de longa permanência como o asilo/casa de repouso, contar com a ajuda de Deus, reconhecimento da importância do empregado doméstico na ajuda do cuidado, estaria morando sozinha apesar das fragilidades, e por fim uma representação bem tímida, mas já presente no imaginário dos idosos, que foi o relato de um idoso quanto ao amparo dos amigos e do serviço de saúde.

A representação que apresentou a maior intensidade, ou seja, a maior força, (LEFÈVRE e LEFÈVRE, 2004), pois um número maior de indivíduos compartilhou a mesma idéia, denominamos Cuidador Competente, Eficiente, Bom Tarefeiro, me Atende em Tudo que Preciso. Os idosos ao enumerarem as competências do cuidador referiramnas com uma carga de sentimentos e com uma riqueza de detalhes da vida cotidiana que trazem à tona a essência do cuidado e o seu sentido na vida desses idosos. BOFF (1999) também sentencia: “O ser humano é um ser de cuidado, mais ainda, sua essência se encontra no cuidado. Colocar cuidado em tudo o que projeta e faz, eis a característica singular do ser humano" (p. 35). 
Para os idosos, seus cuidadores são competentes porque: têm confiança neles, fazem o melhor que podem, são cuidadosos, calmos, estão prontos para ajudar, atendemnos nas atividades cotidianas de suas vidas e por muitas vezes prestam cuidados com conhecimentos técnicos, seguem as orientações médicas com precisão e também cuidam dos afazeres da casa e levam-nos para passear. A competência é um atributo muito importante porque se sentem protegidos e confiantes do cuidado que o cuidador lhes presta. Ela é também mencionada por JOAN ERIKSON 1998 que reflete: “...nós somos classificados segundo a nossa competência... Na verdade, tudo o que fazemos ou tentamos fazer exige um padrão de competência para ser aceitável e compreensível. Não é necessário ser original ou inventivo, mas é fundamental ser competente para destacarse no nosso mundo prático...” (p. 92). O reconhecimento dessa competência de seus cuidadores lhes permite dizer que não precisam de mais ninguém para o cuidado. Possuir a competência através de conhecimentos e habilidades para poderem desempenhar o cuidado é também uma necessidade apontada pelos cuidadores em diversos trabalhos: WANDERLEY (1998), MARQUES (1999), ANDRADE (2001), ROSSETTO-MAZZA (2002), asseverando que se sentem menos estressados e confiantes quando as possuem. A competência então se torna ferramenta necessária e reverenciada pelos idosos. Ouçamos este discurso:

...É muito boa para cuidar de mim tem sido excelente porque ela é muito cuidadosa, muito carinhosa fala calma, explica muito. Eu tenho muita confiança nela. Ela dá conta, a gente se entende nas coisas dela cuidar de mim. Porque ela sempre cuida. Só ela é a mais capaz... Tudo o que eu preciso ela está pronta para me ajudar. Parece uma enfermeira faz curativo todo dia porque eu uso sonda vesical ela limpa, desinfeta, fica preocupada... É esperta, aprende num instante tudo, também segue o que o médico o que o enfermeiro manda, é detalhista e minuciosa no cuidado. Ela cuida demais. Eu me sinto bem assim, cuidada por ela. Tem sido uma filha dedicadíssima porque me dá todos os predicados que eu preciso. Deu iniciativa e providenciou os médicos, as consultas, os remédios. Se eu preciso ir lá ao Centro de Saúde, ela me leva, me ajuda. Todo dia separa o meu remédio, me dá insulina, me leva no banheiro me ajuda no banho, a escovar o dente, me arruma na cama pois não tenho força nas pernas. De manhã eu desço a escada, fico sentada nessa cadeira ela me dá café com leite, pão e manteiga não deixa eu comer o que faz mal. Providencia a alimentação que eu preciso as coisas especiais que eu gosto, frutas que eu quero ela traz da feira. Tudo o 
que eu peço ela me dá até roupa de baixo, pijama, essas coisas, tudo ela compra para mim. Ah! Ela faz todo o serviço, faz a comida lava, passa tudo ela faz... Para sair para a rua não dá, ainda mais que quase eu não enxergo, eu tenho medo de me perder por isso sozinha eu não saio mais. Quando ela vai no supermercado, no shopping me leva para distrair um pouco. Quando ela faz festa na casa dela, Natal, seja o que for, ela leva... Porque é uma boa filha está ajudando bem, está desempenhando bem a função dela...ela faz tudo. Então quando ela sai, a cabeça dela está sempre pensando em mim e eu acho que o cuidado é esse quando a gente está doente e tem quem lhe olhe. É uma boa filha, cuida muito bem, me atende, não é uma menina revoltada e nem nada. . E tenho mais liberdade com a pessoa de casa do que com pessoa de fora para falar e para fazer as coisas também. E para fazer as coisas é que é, porque muitas vezes mexe com dinheiro, com uma coisa e outra, compreende, então tem mais confiança. A gente ta remando enquanto ela está agüentando. A hora que ela não agüentar mais tem que dar um jeito... Ela é muito boa filha, muito boa, não posso falar nada dela tudo o que eu fizer por ela é pouco...Eu sou muito bem cuidada por ela. Tem paciência de estar procurando fazer tudo para agradar, porque além de tudo isso é uma palavra de conforto, de carinho.... Não tinha chegado a essa idade assim como estou, não. Eu teria chegado muito mais acabada, muito mais. Seria só ela... Eu digo com sinceridade, só ela. Eu ainda falo todo dia para ela "obrigada, Deus te abençoe, você vai conseguir tudo na vida pela caridade que você está fazendo..." (Id.1; Id.2; Id.3; Id.4; Id.5; Id.6; Id.7; Id.8; Id.11; Id.13; Id.15; Id.16; Id.18; Id.19; Id.20; Id.21 Id.22; Id.25; Id.26; Id.27; Id.28; Id.29, Id.30; Id.31).

A competência referida é tanto da disponibilidade para o cuidado direto quanto para a preocupação de prestar a melhor assistência. Os idosos são capazes de distinguir um cuidado com disponibilidade e dedicação de um cuidado mecânico e sem afeto. É mencionado nas entrelinhas que a atividade é desgastante e que têm consciência de que o cuidador pode vir a não agüentar mais prestar o cuidado. Com a ausência do cuidador a fragilidade do idoso fica mais exacerbada. Enquanto as famílias assumem os seus idosos, a velhice e suas implicações ficam apenas no âmbito familiar. À medida que a família se distancia e não assume seus idosos e seu cuidado, a problemática da velhice fica mais evidente para a sociedade. $O$ auxílio ao cuidador na sua tarefa com o idoso é a melhor forma de mantê-lo na família e em sua comunidade. O fato de os idosos exaltarem as competências de seus cuidadores nos permite supor que eles sabem e sentem que os idosos sem eles estariam sem condições de sobreviver, porque suas fragilidades são limitantes. 
A representação que nomeamos Sou Objeto fácil para o Cuidado pois sou Independente foi quando os idosos falaram que cuidar deles era fácil porque não davam trabalho, não eram chatos, que ainda eram independentes para as atividades cotidianas, e que até conseguiam ajudar o cuidador no serviço de casa.

A lógica do discurso é um desencadeamento de idéias e justificativas que demonstra a fragilidade que o envelhecimento acarreta a todas as pessoas, e as necessidades cotidianas do cuidado para que tenham uma vida mais agradável e saudável. A descrição do cotidiano de suas vidas com a enumeração de suas habilidades nos adverte de quanto isto é fundamental para o idoso que necessita de alguém por perto para lhe prestar cuidados. Mas o reconhecimento de suas fragilidades e da necessidade de alguém por perto é relativizada na medida em que justificam que também fazem sua parte, tentando agradar e poupar o cuidador de aborrecimentos e contrariedades. O discurso a seguir é proferido por idosos, usando propositadamente como referência a nora (o que não significou que todos os cuidadores eram noras) para melhor entender o significado do cuidado prestado por seus cuidadores:

...Para mim é uma filha, considero como uma filha eu não dou muito trabalho para ela...eu estou cuidando bem de mim porque eu também não sou muito chata... não sendo chata, ela tem mais paciência por que se a gente fosse chata é ruim. Se eu desse muito trabalho para ela também seria ruim. Estou fazendo tudo para ficar independente dela... Graças a Deus, eu não preciso muito eu me viro sozinha. Porque agora eu já estou começando a andar com mais firmeza, mesmo que seja com bengala, andador já dá para eu fazer as coisas... Vou ao banheiro, tomo meu banho sozinha, tiro a minha calcinha, já vou lavar, ou deixo lavadinha no chuveiro, lavo direitinho a cabeça, me troco sozinha... arrumo a minha cama, desço a escada sozinha. Eu sento naquela cadeira ali... e na hora da comida, ela dá comida certa para mim... Toda hora ela está aqui me ajuda muito... É laranjada, é fruta partida, descascada, ela faz tudo, sobre isso eu não posso me queixar. Eu estou fazendo as coisas ainda sozinha... para não ficar dando tanto trabalho para ela... assim, não preciso estar chamando ela toda hora... Tudo o que eu peço ela faz para mim. E também tenho vontade de fazer serviço gosto de lavar uma roupa, é que para ficar passando roupa também eu não agüento muito de pé. Então eu faço alguma coisa, às vezes ela sai e eu falo "tem alguma coisa no fogo que eu preciso olhar", ou se tem pouquinha louça na pia eu dou uma lavadinha, encosto ali e dou uma lavada. Eu estou mais feliz aqui do que em casa porque em casa era muito sozinha era muito grande o apartamento. Então, como eu caí, eu vim para a casa da minha nora... Então por enquanto eu acho que no momento eu não estou precisando 
assim de ajuda... eu faço tudo... Não dou trabalho... Agora eu não sei mais para frente como que vai ser... Só se a pessoa não pudesse mais fazer nada... estivesse na cama. Eu, graças a Deus não estou... A minha vida é muito parada, muito sem novidade. Eu acho que a gente devia morrer mais cedo, não devia viver tanto. Porque depois que você chega a uns 80 assim, já começa.... Eu estava muito bem até 80, 89 anos... Eu viajava ia para a casa do meu sobrinho, ficava lá dias e voltava. E agora, estou fechada aqui dentro, inutilizada. O que me distrai é a televisão e a leitura. Eu leio jornal de ponta a ponta, leio até anúncio. Eu gosto de política também... A única coisa que eu queria era poder andar outra vez e ter minha atividade, de ir à igreja, poder sair, pegar um ônibus. Agora eu não posso nem subir num ônibus. Nem com ajuda não dá. A perna não dá. É duro, viu?... .Ela é demais eu conto com ela... fica preocupada, mas confia em mim porque eu não saio, não dou trabalho, não vou para a rua sozinha... (Id.1; Id.4; Id.9; Id.12; Id.14; Id.17Id.18; Id.23; Id.26; Id.27; Id.28).

Neste discurso notamos claramente o início de suas fragilidades no momento em que admitem que não têm mais condições de viver só necessitando de ajuda.

O envelhecimento provoca nos indivíduos fragilidades e vulnerabilidades, que com o passar do tempo vão se intensificando a ponto de causar diferentes tipos de dependências: físicas, comportamentais, ambientais, sociais. Ser capaz de realizar as atividades da vida diária é o melhor indicador para o idoso de que sua independência e sua autonomia estão preservadas, muito embora saibamos que o ambiente onde ele vive pode ser facilitador ou repressor dessas qualidades. Vimos este discurso, e teremos a oportunidade de ver a seguir um discurso oposto, em que os idosos são obstinados na luta para preservar sua independência e autonomia, porque sabem que sem elas sua capacidade funcional fica aquém do desejado, necessitando invariavelmente de alguém para auxiliá-lo. Portanto, um ambiente acolhedor e encorajador ajuda muito o idoso a preservar o que resta de suas habilidades. BALTES e SILVERBERG 1995 comentam: “...parece plausível esperar mudanças nas condições ambientais que possam encorajar as competências, e não estimular a incompetência e gerar dependência... Os ambientes podem ser estruturados para serem estimuladores e exigentes quanto às forças e competências do idoso" (p. 107).

A importância que o cuidador tem na vida deste idoso dependente é referida nos discursos de uma forma clara e precisa, quando lhe falam da impossibilidade de não estar mais com ele: 
Como seria? Eu ia ter a maior dificuldade do mundo. Como eu estou doente ela não dá conta... a gente quando é independente, faz tudo por conta própria e depois começa a depender, preciso disso, preciso daquilo... Eu tenho uma cuidadora para noite, e uma para de dia para poder me ajudar, me levar para o banheiro, me levantar da cadeira, me sentar na cama, me deitar, me virar, porque eu não tenho condições, meu corpo, meus braços doem. Eu não tenho condições de me virar sozinha... Para mim é difícil viver pedindo. Eu sei que estou sendo importuna... apesar de não ter culpa. Elas (filhas) sabem disso, mas eu sei que seria bem melhor se eu ocupasse elas menos do que ocupo...porque eu não estou sendo capaz de me locomover sozinha, de pegar a cadeira de roda e mexer sozinha, de coçar a minha cabeça, de coçar o meu corpo, porque os meus braços, os meus dois braços, os meus ombros, ficam muito atingidos, muito prejudicados... sinto muita dor, muita dor... Com esse remedinho, tem hora que eu tento me virar. Apesar de toda dificuldade eu estou me movimentando, procurando me virar...mais assim mesmo eu mexo com ele com muita dificuldade. Eu tenho muita força de vontade. Não posso levantar ele muito e o braço que está imobilizado, esse daí eu vou ter que fazer fisioterapia. Todos os dois braços estão difíceis de locomover... A artrose é uma doença muito, muito... Judia demais da pessoa... (Então) é muita coisa para uma pessoa só fazer. A minha filha orienta, supervisiona a minha vida, o meu físico, a minha saúde, os meus mal estar e tudo, mas não dá conta sozinha. Mas também ela não anda com muita saúde. E está sem força, o pior de tudo é isso, ela está sem força... Mas tem uma força de vontade tremenda. E me cuida, viu? Ela não descuida de mim, não. Muito nervosa, às vezes, meio bravinha, aí eu brigo com ela também... Quando está um pouquinho de mau humor, eu também reajo... É por isso que eu queria ficar independente. A coisa mais triste do mundo é a gente ter que pedir para os outros ajudar a gente quando a gente não pode. E é duro, não é fácil. Eu sei que a gente dá trabalho. Eu sei, eu tenho consciência, eu não sou boba. Eu sei do que acontece na vida real. Eu tenho uma experiência de vida muito grande. E a gente sabe definir de tudo na vida... (Id.11; Id.13).

A literatura é extensa quando o assunto diz respeito ao idoso dependente e ao estresse do cuidador. Os trabalhos são numerosos, teses são feitas sobre o assunto. Os idosos do nosso trabalho expressam quanto é difícil tanto para os cuidadores como para eles o desempenhar cotidiano do cuidado quando são severamente dependentes. Esta dependência física (não estamos nos referindo a outro tipo, por exemplo cognitiva,que é muito pior) exige que outras pessoas sejam envolvidas no cuidado porque o cuidador não é capaz sozinho de executar o trabalho, e se o faz, é devastador, prejudicando-o a ponto de adoecer. Este discurso ilustra bem como as famílias e seus cuidadores estão vivenciando o cuidado aos seus idosos. Os dizeres desses idosos trazem à tona: o estresse da execução do cuidado, a necessidade de suporte financeiro para o custeio 
desses idosos, a necessidade de conhecimento sobre o cuidado por parte dos cuidadores, o acompanhamento e o apoio de equipe interdisciplinar de saúde para assistir essa família e o idoso, e equipamentos sociais para dar suporte aos seus membros, etc. São muitas as necessidades que as famílias encontram no seu cotidiano de cuidados. O que verificamos no nosso trabalho como profissionais é a solidão e o desamparo a que estão submetidas. Estratégias de apoio governamentais nos três níveis de governo estão sendo implementadas, porém temos muito que fazer para auxiliar essas famílias e basicamente seus idosos, lembrando das diferenças regionais brasileiras, como distinguem os pesquisadores quando advertem que temos diferentes Brasis.

A importância que os cuidadores familiares têm na vida desses idosos também pode ser verificada na representação que nomeamos Só tenho ele para cuidar de mim. Não tenho mais ninguém, só ele, onde os idosos mostram o valor dos cuidadores não apontando outra alternativa, a não ser ficarem sozinhos. Assinalam que há outras pessoas na família, mas que não seriam prováveis cuidadores. Descrevem as atividades que deveriam fazer sozinhos, com um futuro também de solidão. Este discurso faz uma projeção de como seria o cotidiano e os sentimentos dos idosos que porventura viessem a perder o seu cuidador, ficando sem apoio para o auxílio de suas necessidades. Estes idosos são vulneráveis na medida em que não tendo mais ninguém da família para se responsabilizar por eles necessitam do amparo do Estado, com a provisão de políticas públicas de amparo social e de saúde para suprir a ausência da família. Um contingente considerável desses idosos nestas condições já se apresenta nos prontos-socorros dos hospitais, nos serviços de saúde e sociais e nas ruas das grandes cidades. Fica evidente através de suas falas a sua fragilidade, bem como da sua unidade familiar e do Estado brasileiro. As famílias, por sua vez, não lhes prestam assistência e por motivos diversos negligenciam os idosos. O Estado não cumpre com o seu dever, que é o de proteção às populações mais vulneráveis. O resultado desta situação são perspectivas sombrias de futuro para os idosos, gerando uma velhice sem esperanças e sem dignidade. Vamos ouvi-los: 
Eu não sei o que seria de mim.. eu acho que eu morria à mingua porque não tinha ninguém para cuidar É dose a gente ser sozinha porque não tem mãe, pai, não tem marido e estou velha. Tenho irmã, netos mais nem sempre estão bem para ajudar e a gente também não pode ficar perturbando eles para fazer certas coisas... Então é ela que cuida de mim todo dia ela separa o meu remédio...Se não tivesse ela teria que me arrumar sozinha teria que me esforçar mais para não esquecer de tomar o remédio, para lembrar de outras coisas, me preocupar... Pegaria um táxi iria ao supermercado sozinha, faria a compra e fazia a comida... Mas ela me cuida muito bem, graças a Deus. Deus que ajude ela, que dê bastante saúde porque para enfrentar o que ela enfrenta aqui, é dose. Ela é até forte demais... Se não fosse ela eu estava aí, só jogada no mundo. Às vezes eu penso meu Deus quem vai morrer primeiro, eu preciso morrer primeiro porque eu não posso ficar sem ela, porque eu não posso andar por aí e os meus filhos têm a vida deles. Então eu vou sentir muita falta dela se ela for...se morrer primeiro que eu. Eu preciso muito dela. Não faço idéia de como será a vida sem ela...(Id.1; Id.3; Id.7; Id.9; Id.15; Id.18; Id.19; Id.21; Id.25).

Para completar este discurso apresentaremos uma ancoragem de cuidadores de idosos do trabalho de ROSSETTO MAZZA 2002 onde expressam seu sentimento de indignação com a situação de descaso para com os idosos:

“Eu acho um despautério contra os pais, agora eu vejo isso na rua e não muito longe, perto da minha casa, senhoras jogadas, senhoras mães jogadas ai na rua, é um negócio chocante para a sociedade isso. Eu acho um negócio negativo não só para a família como uma parte, nesse momento tão difícil em que vivemos aqui em São Paulo e em todo o Brasil” (p. 65).

SANTOS 2003 também adverte: "No Brasil há o abandono dos idosos dependentes e de seus cuidadores familiares à sua própria sorte" (p. 22).

Ao confrontarmos os dois discursos verificamos a apreensão que estes sujeitos, sejam eles idosos ou cuidadores, estão vislumbrando sobre o futuro próximo, e como têm consciência do descaso do Estado e também da sociedade em não proporcionarem melhores condições de amparo à velhice. As estratégias de sobrevivência estão sempre pautadas em habilidades próprias, e na ausência delas o idoso não é capaz de encontrar outro meio a não ser ficar jogado no mundo. Este discurso é um alerta para nós de que precisamos pensar em como estaremos, a curto prazo, resolvendo a questão do amparo à velhice para os próximos anos, quando o contingente de idosos será muito maior. Outro 
fato demonstrado neste discurso é que os idosos têm consciência do tipo de cuidadores com que poderiam contar: pai/mãe e o cônjuge mas não mencionam os filhos. Esta situação é cada vez mais alardeada pelos estudiosos pelo fato da participação da mulher no mercado de trabalho, deixando o seu papel de cuidadora da família.

Outra forma de expressar a importância exclusiva do cuidador é este discurso que exporemos a seguir, quando usamos o sujeito esposa para ilustrar o que ocorre rotineiramente nas famílias onde um dos cônjuges fica fragilizado, necessitando de cuidados. A responsabilidade pelo cuidado fica exclusivamente voltada para o cônjuge que pouco conta com a ajuda dos filhos ou de outra pessoa, gerando o fenômeno muito comum e referendado por todos, inclusive pelos sensos demográficos, onde registram os cônjuges idosos cuidando de seus parceiros idosos. Os serviços sociais e de saúde que atendem estes idosos rotineiramente se deparam com esta situação, possuindo poucas condições de auxílio a essas pessoas. O problema está visível e deverá ser enfrentado de maneira consciente e responsável efetivando ações de proteção, de promoção, prevenção e recuperação de agravos tanto dos idosos como de seus idosos cuidadores, retardando sua dependência e problemas mais importantes de saúde.

Os idosos, através de seus discursos nos mostram como estão vivendo e quanto necessitam de cuidados. Acreditamos que ações competentes no âmbito da saúde pública sejam o caminho mais adequado para auxiliá-los nessa tarefa. É preciso haver políticas públicas para eles e suas famílias, que protejam esses idosos fragilizados e dependentes. À medida que os serviços de saúde atendem suas fragilidades, os cuidadores sentem-se amparados e o cuidado passa a ser compartilhado por todos.

Eu acho que ele é suficiente por enquanto ele está com a cabeça boa não está com o disco bom...eu não preciso de ninguém mais não porque eu não tenho ninguém mais, só ele. Então por isso que eu não gosto nem de pensar como será sem ele. Porque se não fosse ele se não tivesse ele... Eu acho que dependendo das minhas condições eu estaria num canto aí qualquer desses que botam a pessoa de lado e deixam ela lá... Mas ele não me deixa....Porque os meus filhos têm mais dificuldades, um que mora longe, outro que mora aqui pegado mais tem muitas atividades, tem 3 filhos pequenininhos, tem um nenê que nasceu agora, tem 2 meses. Então seria muito difícil deles me ajudarem... Até as consultas ele vai comigo. Ele fica naquelas filas do HC para pegar 
remédio para mim, ele tem que ir a pé até lá. Então ele é muito especial nesse assunto. Agora se não tivesse ele, eu não sei o que seria de mim. Eu tinha uma sobrinha, que morreu, faz 1 ano e pouco, ela me adorava. Aquela nossa senhora. Eu podia contar também... Ela era outra pessoa boa. Agora eu estou bem depois eu não sei....Se um dia não tiver mais ele ou se eu for antes...Mas ele não vai me deixar na mão. Não vai não, eu acho que não... O sonho da minha vida era ter uma família e eu consegui. Ter uma família, os filhos... Ele é muito especial para mim se eu não tivesse casado com ele, eu ia querer casar com ele, a vida toda... Eu ia querer casar com ele.. .(Id.3; Id.5; Id.22; Id.25; Id.26).

Quando atendemos essas famílias e seus idosos percebemos que o cuidador idoso cônjuge protege o seu parceiro, e ao mesmo tempo garante a sua permanência na família; de uma maneira ou de outra ele assume o cuidado. SAAD 2004 também opina sobre isto: "Os cônjuges idosos são os principais provedores de ajuda em Atividades de Vida Diária e Atividades Instrumentais de Vida Diária... são as esposas, mais especificamente, as grandes provedoras de auxílio aos seus maridos idosos" (p. 199).

SANTOS 2003 complementa que quando um dos cônjuges adoece ou fica fragilizado, é sobre o seu parceiro que recai a responsabilidade pelos cuidados diretos.

Com a ocorrência da morte do cônjuge cuidador o risco para o idoso dependente que permanece vivo é potencializado, pois o cuidado fica a cargo dos filhos ou de outro membro da família, que muitas vezes não estão disponíveis para o cuidado. A urgência de políticas públicas, através de investimentos tanto financeiros quanto de recursos humanos especializados, para favorecer e auxiliar estas famílias de idosos dependentes e também os idosos que vivem sós, os quais são os de maior risco, é o que se espera do Estado para atender a esta demanda tão necessitada. Nos países, como o Brasil, que ainda necessitam de estrutura governamental de apoio às populações mais vulneráveis, a presença da família para assumir seus dependentes é a única saída digna para eles. Nós, que estudamos o envelhecimento e suas consequiências, sempre mencionamos o importante papel da família nesta atenção.

Ao nos reportarmos à representação dos significados do cuidado e da família para os idosos, citaremos o que SANTOS 2003 explica: “...o cuidado é comum em todas as culturas, embora suas formas de expressão possam ser as mais variadas; se buscarmos 
um ponto em comum a todas, verificaremos que parece ser a família quem essencialmente executa e se responsabiliza pelo cuidado" (p. 13).

O tema Família pode ser discutido pelos enfoques demográfico, antropológico, social, psicológico, legal, enfim, por diferentes tipos de corrente ideológica. A representação a seguir pretende mostrar o que os idosos, escolhidos para compor a amostra, expressam sobre a família e sua importância para eles. Algumas considerações sobre esta instituição serão apresentadas para que possamos contextualizar este tema.

FARO 2000 pondera que "família vai muito além de ser definida pela sua composição. Na sua conceituação é preciso considerar que se trata da união de pessoas, com vínculos emocionais, afetivos, de interesse ou legais, vivendo juntas por um determinado período de tempo, em um lócus social, com suas regras, valores, crenças, deveres e responsabilidades com vistas às suas metas no ciclo de vida" (p. 27).

CANO e FERRIANI (2000) explicam, citando Romanelli, que "na sociedade brasileira atual, o modelo de família nuclear é hegemônico e visto como ideal a ser seguido pela maioria das pessoas, mas esse modelo tem sofrido fissuras e outros arranjos familiares têm surgido, percebendo-se um aumento do número de famílias matrifocais como resultado de diversas causas” (p. 31).

FARO 2000 reitera: “...a família sofre uma evolução natural na medida em que a sociedade também se modifica. Enquanto instituição social primária, tende a refletir e reproduzir o sistema social vigente" (p. 28).

A pesquisa nacional do Datafolha, de outubro de 2007, referente à família, brasileira constatou que após nove anos da última pesquisa esta família continua sendo a instituição mais valorizada para os brasileiros, e sugerem que isto ocorre porque ela está se adaptando à modernidade, com mais tolerância sexual de seus membros, afrouxando conceitos e controles.

O que verificamos é que a família atual, embora esteja se distanciando do modelo nuclear, ainda é a instituição que melhor ampara os seus membros mais vulneráveis. Isto não significa que não existam conflitos, desentendimentos e disputas internas, mas o que verificamos é que novos arranjos são construídos e novas estratégias de cuidado são 
criadas, muitas vezes com a presença de outros elementos para o auxílio desses membros mais vulneráveis. Estes novos arranjos familiares, quando são criados para atender os idosos, são predominantes do tipo de idosos(as) residindo com filhos. A forma deste arranjo é pela co-residência “...com a transferência de bens e recursos financeiros. Os seus membros se ajudam na busca do bem-estar coletivo constituindo um espaço de conflito cooperativo em que se cruzam as diferenças entre homens e mulheres e as intergeracionais..." (CAMARANO et al., 2004, p. 52).

A distribuição de tarefas e a reorganização das funções dos componentes familiares geram conflitos e estresse, mas desses rearranjos emerge sempre um cuidador que se responsabiliza pelo cuidado ao idoso. Muitas vezes esta nova função não é espontânea, mas imposta, tornando o cuidado mais pesado e oneroso para o escolhido, que na sua grande maioria são as mulheres, filhas viúvas, divorciadas ou solteiras. Se as relações da díade durante sua história de vida foram harmoniosas e permeadas de respeito entre as partes, o estresse e a tensão do cuidado são minimizados, passando o familiar a desempenhar a tarefa. Se as relações foram conflituosas durante o ciclo de vida dessas pessoas, a disponibilidade de seus membros para assumir o cuidado fica grandemente prejudicada, insuficiente, ou até permeada de violência e maus-tratos com o idoso.

Em conversa com esses idosos que são desamparados pela família, frequentemente são apontadas diferentes razões que levaram os familiares a tomar esta decisão. O imaginário social é de que este idoso está recebendo o que acumulou durante sua existência. Esta ponderação é compartilhada também por CAMARANO et al. 2004 quando indicam: “... a construção de laços afetivos ao longo da vida são requisitos tão importantes para o apoio na última fase da vida como a contribuição para a seguridade social" (p. 162).

DUARTE, 2001 também relata em sua tese de doutorado que "as relações entre os idosos e seus familiares são influenciadas pelas relações que foram construídas durante toda uma vida e são significativamente importantes na construção de uma rede de suporte e na manutenção de uma família saudável nos anos mais tardios” (p. 30). 
Na concepção de SAAD 2004 "as relações de troca e ajuda mútua entre pais e filhos são os principais fatores que têm assegurado, ao longo da história, a sobrevivência nas idades avançadas" (p. 169).

A certeza de que além do cuidador principal existem outros membros familiares que poderiam auxiliá-lo caso tivesse necessidade é a essência desta representação. A importância do cuidador é referida, mas também há no imaginário desses idosos a certeza do amparo oferecido por outros familiares, proporcionando uma rede de suporte tanto para ele como para seu cuidador principal.

GOLDANI 2004 afirma que "a família brasileira não é apenas uma importante fonte de apoio material, mas é percebida, também, como a principal fonte de alegria e felicidade para os idosos" (p. 235).

O discurso a seguir é uma demonstração de quão importante é a família e seus membros para esses idosos. O que podemos verificar neste discurso é a segurança de que serão amparados por eles.

...Não, não, para cuidar de mim eu acho que não precisa eu tenho também, a minha mulher que cuida de tudo compreende? Ela também ajuda. Ela faz a comida, me dá tudo em ordem, a tempo, isso eu não posso me queixar, porque ela é uma boa dona de casa. Eu tenho três filhas, um filho a minha nora não conto muito, mas eu acho que se precisar ela cuida sim, porque ela cuidou muito da avó dela. Tem a minha neta que também vem (Uma das minhas filhas) vem sempre por aqui, para dar uma mão. Ela é muito boazinha para me cuidar. Daqui a pouco ela vai chegar aqui para almoçar, todo dia ela vem... Bom, aqui eu recebo um tratamento ímpar de todos. Tem, o (meu genro) que é incansável. Durante a minha vida toda eu nunca o vi, digamos assim de mau humor. Sempre com aquele sorriso, sempre pronto para ajudar, sempre pronto para fazer alguma coisa. Então isso aí tudo a gente tem que agradecer a Deus. ...Então eu penso que um pouco com cada um vamos dividir se eu sair daqui eu fico dias numa casa e na outra, posso ficar em todas elas. Eu penso que se fosse (preciso) não estando ela, eu tenho outra filha, que se precisasse, ela também ficaria comigo. Às vezes eu vou lá, quando não tem médico em seguida aqui, eu vou ficar uns tempinhos lá. Eu tenho um quarto lá. A minha cama de casal tem minhas coisas lá. Às vezes, eu passo uns 15 ou 20 dias com ela, depois eu volto para cá. Tem também uma sobrinha no interior que se eu quiser ir para lá, se eu não tivesse eles sempre fala "ah, tio, quando você precisar pode vir aqui que eu cuido de você". Ela é muito boa, ela é professora mais está aposentada. Ela sempre fala... Mas eu estou bem aqui... Ah, também minha irmã se eu precisar ir ao médico ela vai...Vai todo mundo...Só que está precisando é ajuda de, como se diz? De 
dinheiro que o meu filho e minha filha de vez em quando me ajudam. Se não fosse a minha filha, coitada, a minha nora não pode pagar porque, ela também está doente. Mas se não fosse...eu garanto que ela faria tudo para me ajudar. Isso eu tenho certeza. Então eu acho que outra pessoa não precisa porque ela faz de tudo. Se não fizesse sim, mas ela faz de tudo...(Id.2;Id.3; Id.4; Id.6; Id.7; Id.15;Id.18; Id.20; Id.22; Id.24; Id.28).

Na opinião da autora “...o contrato intergeracional entre os membros da família é mantido por um conjunto de fatores como: laços de afeto, sentimentos de reciprocidade sobre a vida, poderosos incentivos econômicos ou sanções negativas e amplos valores culturais..." (idem, p. 228).

Há diversas famílias onde a presença de netos e outros membros é comum nos arranjos familiares, possibilitando um maior comprometimento deles no cuidado com os idosos. O que notamos é a existência da cooperação, do compartilhamento das ações do cuidado e uma valorização da figura do idoso. Podemos considerar também a existência de conflitos, porém a probabilidade de trocas de experiências, de transmissão de valores e conceitos é mais facilmente verificada nesses arranjos familiares. A presença de um membro idoso geralmente preserva as tradições e o patrimônio cultural do grupo de origem. Quando este grupo familiar não valoriza tal presença ocorre o que Roseli Sayão descreveu em uma crônica de junho de 2007, onde explica que há duas hipóteses para o esquecimento da história das famílias. Primeira hipótese: “...no mundo admiravelmente novo a cada dia as tradições familiares...quando não são simplesmente esquecidas são consideradas ultrapassadas, autoritárias, rançosas. Perderam mais que o valor: perderam o lugar." Segunda hipótese: "sendo a família um local de grandes conflitos, o melhor a fazer seria tentar colocar o passado entre parênteses para criar uma nova família...para tentar anular antigos problemas". No nosso ponto de vista, a presença de diferentes gerações em um seio familiar pode provocar conflitos e muitos questionamentos entre seus membros, mas também um exercício de tolerância entre eles. O discurso abaixo é um exemplo do convívio e de trocas intergeracionais entre seus membros: 
...O meu genro também é muito bom. É uma pessoa que, não é de falar que é genro ruim, que fala da sogra. Não, ele é muito bom. E o meu neto também, melhor ainda, porque quando eu fiquei ruim, ele me dava comida até na boca. Eu ia comer e a colher não acertava, pegava no nariz, e ele falava 'vó, eu vou te dar a comida'. E eu não estava nem conhecendo que era o meu neto... E as minhas filhas...ficam sempre preocupadas, se uma não pode vir aqui em casa, ela liga 'olha, mãe, ainda estou aqui no serviço, vou chegar muito tarde e não vou em casa hoje'...E a outra que mora em Maceió liga toda semana, 'mãe, está boa?'. Ontem até ela falou assim para mim 'mãe, está difícil falar contigo'.. .... Eu também tenho uma sobrinha, pediu que eu fosse morar mais ela ...Eu fui na casa dela, deixei a mala lá com tudo, para voltar, mas imagina eu deixar o meu filho aqui só...A minha filha de Maceió vem agora aí, vai ficar 2 meses comigo aqui. Não vejo a hora que ela chega...(Id.4;Id.19;Id.23).

CAMARANO et al. 2004 enfatizam a importância das relações entre avós e netos: “...os indicadores sociais sugerem a existência de co-residência de várias gerações como forma significativa de arranjos familiares em que se inserem os idosos brasileiros... onde são compartilhados entre as várias gerações experiências, valores, suporte financeiro e emocional destacando as relações entre os netos e avós"(p. 149).

O discurso a seguir é interessante na medida em que é a família e não outra instituição que é lembrada, pelos idosos, para executar o cuidado na hipótese de não haver mais os cuidadores principais para lhes prestar ajuda. O tom de insegurança é perceptível quando enumeram prováveis cuidadores que podem ser parentes próximos, ou mais distantes, amigos e vizinhos. A importância do cuidador atual fica explícita nas entrelinhas, onde podemos perceber certo temor por parte dele quando assegura desconhecer dentro do seio familiar maus-tratos ou mesmo ausência de cuidado, descartando a possibilidade de isto vir acontecer com ele. Pode haver esta falta em outras famílias, mas não nessa.

AQUINO e CABRAL 2002 identificam: "nas condições brasileiras, os cuidados aos idosos são prestados predominantemente por suas famílias e na falta destas, por amigos e vizinhos" (p. 1059). 
...Seria difícil isso é duro não tenho idéia...Seria estar ao pé de um outro, sei lá, da família da gente...Eu tenho mais parente tenho dois irmãos, oito sobrinhos, um filho, uma filha, meu neto, várias pessoas aí que são vizinhas e que são preocupadas comigo. Gostam de mim e se eu precisar delas, elas me acolhem também. Na minha família nunca aconteceu isso de maltratar, de não cuidar. Porque todo mundo que fica doente um ajuda o outro. Então não tenho idéia. Eu vejo falar... falar a gente vê, mas eu não posso falar nada porque nunca aconteceu, agora que está acontecendo. Então eu não tenho idéia assim se eles pudessem me pôr em algum lugar... mas isso nunca vão fazer...por enquanto eu estou aqui... Já tem um tempo que eu estou aqui com ele.. .por isso eu digo, que não deixo o meu filhinho só não...Eu tenho muito parente...muito parente...mas não vou deixar ele sozinho...(Id.7; Id.20; Id.22; Id.23; Id.28; Id.29)

As autoras citadas analisam: "a família parece ser um ponto de referência em todas as situações... É o elemento mais freqüentemente mencionado por idosos como importante ao seu próprio bem-estar...” (p. 1057).

$\mathrm{Na}$ pesquisa com pessoas idosas de diferentes camadas sociais paraibanas, estas autoras comprovaram que a maioria dos idosos declara que sua constituição familiar é boa, valorizando sua vida doméstica. As dificuldades de relacionamento são levemente insinuadas.

Este discurso dos idosos sutilmente faz menção sobre um tema que muitos pesquisadores e a mídia vêm apontando sobre os riscos de violência doméstica contra os idosos.

DEBERT 1999 adverte sobre os possíveis maus-tratos a que são expostos alguns idosos por seus membros familiares, e elucida: "o fato dos idosos viverem com seus filhos não é garantia de presença do respeito e prestígio, nem da ausência de maustratos. As denúncias de violência física contra os idosos aparecem nos casos em que diferentes gerações convivem na mesma unidade doméstica. Assim sendo, a persistência de unidades extensas não pode ser necessariamente vista como garantia de uma velhice bem-sucedida, nem o fato de morarem juntos um sinal de relações mais amistosas entre seus filhos" (p. 83).

Os discursos apresentados sobre a importância que a família tem para os nossos idosos é uma demonstração de que no Brasil, pela ausência e inoperância de políticas sociais e de saúde voltadas para as camadas mais vulneráveis da população, recai 
somente na família a responsabilidade do cuidado. A expectativa deste cuidado é reforçada nesta ancoragem que identificamos nos discursos a qual denominamos: $A$ família é que deve cuidar:

...Ah eu não sei o que seria de mim e do (meu marido) porque a (minha outra filha trabalha), e a gente não tem aqui ninguém assim... que seja... família perto...(Id. 19).

No imaginário dos idosos e também da nossa sociedade a primeira instituição lembrada e esperada para executar o cuidado é a família. A própria Constituição brasileira preconiza o amparo e a responsabilidade por parte dos familiares no cuidado aos seus membros mais vulneráveis.

Nós, pesquisadores e profissionais que lidamos com os idosos e seus familiares nessa relação de cuidados, julgamos ser urgente e necessário propor estratégias de construção de redes de apoio sociais, com o objetivo de proteção dessas unidades familiares proporcionando-lhes meios para que possam ter condições de cuidar de seus membros mais vulneráveis, com uma vida menos estressante e desgastante para todos.

CAMARANO e PASINATO 2004 resumem a situação: “...as demandas de cuidados por parte do segmento `dependente` recaem quase sempre sobre a família” (p.13).

$\mathrm{Na}$ representação que denominamos Teria que encontrar outro cuidador, o discurso mostra como a perda gradativa da independência é prejudicial aos os idosos. Mostra também o exercício pleno da sua autonomia na medida em que têm controle sobre sua vida e têm capacidade de decidir o melhor para eles. A procura por mecanismos compensatórios e novas estratégias para contornar as adversidades oriundas do envelhecimento são mencionadas e evidentes quando ponderam que necessitam de outra pessoa, "seja ela quem for" para o auxílio no seu cotidiano. A preservação do entorno favorável no sentido de estimulá-los em suas escolhas e decisões, respeitando e valorizando suas pessoas é o que esperam os idosos.

Confirmando, SANCHES 2000 observa: “...Há um profundo pesar não pela perda funcional mas pela perda de liberdade de escolha, do poder decisório, do real 
sentido de viver (p. 50). A perda da capacidade cognitiva, com o comprometimento de sua autonomia e independência, é uma sombra amedrontadora que paira no imaginário dos idosos.

BALTES e SILVERBERG 1995 reconhecem: “...por causa da crescente vulnerabilidade biológica e do confronto com a principal tarefa evolutiva da velhice, que é a aceitação da própria finitude, tanto a integração social quanto a autonomia pessoal assumem capital importância...” (p. 102).

Os idosos do nosso trabalho expressam-se de maneira simples e lógica sobre os mecanismos de escolha para uma sobrevivência autônoma e digna. JOAN ERIKSON 1998 em suas reflexões também relata: “A autonomia, pensem em como é, em como sempre foi, querer todas as coisas da nossa maneira. Eu desconfio que este impulso continue até nosso último suspiro...” (p. 91).

Talvez um dos pontos de tensão e conflito na relação de cuidados resida nessa preservação obstinada que os idosos têm de resguardar sua dignidade como seres humanos. A dignidade para eles é poder decidir o que, como e quando fazer determinada atividade.

A importância do cuidador é mencionada pelo idoso na medida em que supre as suas necessidades, preserva sua vontade e estimula suas decisões. É um coadjuvante na sua vida, pois o controle de sua vida está em suas mãos e não na do cuidador. A lucidez que pode ser vista neste discurso é a prova de que os idosos, embora necessitados de cuidados para as atividades cotidianas, têm condições de decidir o melhor para si próprios. Este discurso é rico em representações sobre a busca incessante de liberdade de escolha para conviver com a dependência. Ouçamos o discurso:

Teria que arranjar uma pessoa amiga, ir para a casa de um filho, ou para a casa de uma irmã. Colocar uma empregada, uma pessoa aposentada. Alguém que conhecesse para se responsabilizar pela gente, para acompanhar, para fazer companhia, pelo menos ficar junto para cuidar... Então eu teria que buscar outros recursos de sobrevivência e escolher um deles que fosse a melhor opção porque eu acho que a pessoa não pode se entregar de todo... ele deve descobrir aquilo que precisa, o que pode fazer, e o que pode receber porque eu não tenho condições eu tenho um pouco de dificuldade para andar, não tenho mais estabilidade como tinha de primeiro. Preciso 
andar de bengala tenho muita dor nas costas não vou sozinha no banheiro, e quando estou com sede, preciso pedir água para alguém...não tenho condições de pegar um ônibus e ir para cá e para lá. ...Então é uma coisa mais complicada para mim se não tivesse ele porque é uma grande ajuda que ele me dá... Precisaria de outra pessoa para ficar comigo nem que fosse pelo menos até um meio-dia. Não tinha jeito teria que arrumar alguém... (Id.1; Id.2; Id.4; Id.10; Id.12; Id.16; Id.20; Id.24; Id.29).

A representação Teria que ir para casa de repouso mostra a importância do cuidador para esses idosos, quando admitem não possuir mais ninguém para prestar-lhes cuidado e acompanhá-los no seu cotidiano de vida. Diferentes pesquisadores apontam prós e contras do asilamento e suas conseqüências na vida dos idosos, citando os fatores de risco, tais como: morar só; ter suporte social precário e baixa renda, doenças crônicodegenerativas e suas seqüelas, hospitalizações recentes e dependência para realizar as AVDs como: cuidar da própria higiene, alimentar-se "(CHAIMOWICZ e GREGO, 1999, p. 455); necessidade de cuidados especiais para os idosos com mais de 75 anos pela maior incidência de demências, deterioração física e cognitiva, levando à dependência total e impossibilidade de recuperação, mudanças na dinâmica familiar com a introdução da mulher no mercado de trabalho; problemas de habitação, com sua redução e inadequação; inexistência de: apoio domiciliar, grupos de apoio aos familiares e por último, ausência de centros-dia. (ROOSE e BUZEKI, 1999; TELLES FILHO e PETRILLI FILHO, 2001).

A idéia negativa das casas de repouso é claramente exposta neste depoimento quando mencionam não saber o que será deles caso isto aconteça. Entre os estudiosos há também a prevalência da idéia de que o asilamento provoca o isolamento, a baixa autoestima, entre outros efeitos, mas também há a ponderação de que estas instituições são importantes para aqueles idosos que vivem sós e não têm recursos financeiros, e para aqueles que são totalmente dependentes, sem possibilidade de recuperação.

Uma pesquisa realizada em Santiago de Cuba indica que os idosos, na sua maioria homens que viviam sós, consideravam a instituição um lugar de proteção, seu verdadeiro lar, a garantia de uma velhice tranqüila (BELL et al., 1999).

ROSSETTO MAZZA 2002 encontrou também junto aos cuidadores familiares entrevistados, representações sobre a possibilidade de asilamento, tais como: a família 
cuida melhor; a institucionalização é a solução para os idosos que não têm respaldo familiar e de um cuidador; o asilamento provocaria o fim, a morte do idoso; o asilo é a solução para idosos dependentes e inconscientes que necessitam de cuidados especiais; alguns idosos não aceitam a institucionalização (p. 93). Podemos verificar que as justificativas/representações dos cuidadores são semelhantes às dos pesquisadores. $\mathrm{O}$ discurso a seguir mostra a fragilidade do idoso e a importância de seu cuidador:

...Se eu não fosse cuidada por ele...hum, como que eu vou responder isso?...não tenho idéia, nunca pensei nisso também...eu tinha que ir para a casa de repouso, um hospital, uma entidade, talvez em algum sanatório enfiada... Quem ia me cuidar? uma enfermeira em casa é muito caro fica um pouco difícil. Morar sozinha eu acho que não conseguiria porque com a minha doença eu não posso levantar a qualquer hora, a pessoa não vai querer. Não teria mais ninguém para cuidar de mim. Os filhos têm a sua vida acho que não ficariam procurando por mim para me cuidar. Para dizer a verdade, para a casa dos meus filhos eu acho que não porque nora é diferente de filho, de filha. Acho que não tem o que falar... quer dizer, que se não tivesse ele eu estava no asilo hoje. Não sei se eu estava viva ou se eu estava morta, eu não sei, eu sei que eu estava lá...(Id.5; Id.6; Id.8; Id.11; Id.26; Id.27; Id.30)

Outro dado interessante encontrado nos depoimentos foi que para estes idosos há uma diferença entre asilo e casa de repouso. Pelas suas falas pudemos encontrar uma ancoragem que chamamos de Asilo é para Idosos pobres e Casa de Repouso para quem pode pagar. $\mathrm{O}$ imaginário da diferença entre asilo e casa de repouso deve-se ao que BORN e BOECHAT 2002 esclarecem: "asilo associado à pobreza e ao abandono não mereceu atenção até anos recentes, daqueles que se interessavam por trabalhos de cunho científico... ...As instituições para os idosos, na sua origem, local de segregação o que, até hoje, ainda, são em grande número...”(p. 768). Atualmente no Brasil as instituições de longa permanência para idosos são de dois tipos privados: filantrópicas/benevolentes, mantidas por religiosos, imigrantes ou descendentes com longo trabalho assistencial de caráter asilar, e clínicas geriátricas ou casas de repouso, com finalidades lucrativas, que ficam localizadas nos grandes centros urbanos. Nos municípios menores ou nas regiões menos desenvolvidas encontram-se apenas as instituições benevolentes/filantrópicas. As 
instituições de longa permanência governamentais são em pequeno número (idem, p.770). A ancoragem encontrada ilustra o exposto pelos pesquisadores:

...Só se eu fosse para uma casa de...não digo asilo porque asilo é meio pesado... Mas para uma casa de...como é que a gente fala? ...Uma casa de idosos... Que eu pagasse para ficar nessa casa. Não assim como um asilo... que fica lá, um idoso que não tem... que não tem condições de pagar... (Id. 27).

CAMARANO et al 2004 atestam que: "os cuidados de longa permanência não constituem uma prática comum nos países do Hemisfério Sul” (p. 139).

A representação a seguir Só teria ajuda de Deus diz respeito à religiosidade marcante em alguns idosos, que exaltam o cuidador na condição abaixo de Deus. A ajuda divina é lembrada quando mencionam não existir mais ninguém para cuidar deles. A expectativa do amanhã é incerta porquanto a fragilidade e o desgaste que o envelhecimento produz em seus corpos fazem com que não confiem mais em sua capacidade de superação, própria dos indivíduos mais jovens.

“...O jeito é ficar aí como Deus quer... Deus toma conta também. Agora eu estou mais ela, como se diz... Está bom, porque ela está, abaixo de Deus, é ela que está olhando para mim..." (Id.1)

A força que esperam receber de Deus para continuarem vivendo de modo digno é o que restou para esses idosos. A presença de Deus em suas vidas auxilia-os para suportar o inesperado e as adversidades. GOLDSTEIN eSOMMERHALDER 2002 dizem que “...a religião pode fornecer um sentido, um significado à vida que transcende o sofrimento, a perda e a percepção da mortalidade" (p. 951).

A procura do divino é o caminho que alguns idosos usam para explicar e aceitar suas perdas, suas decepções, suas crises tão presentes no seu cotidiano. É um recurso individual da pessoa que busca força, conforto, superação da adversidade para continuar a viver. Estar em contato com um Ser maior e confiar Nele são condições para o desenvolvimento do sentido da vida. Esta crença põe o individuo em contato com o sagrado, com a sua espiritualidade, com o modo de estar no mundo e com as pessoas. 
BOFF 1999 diz que "o ser humano pode cultivar o espaço do Divino, abrir-se ao diálogo com Deus, confiar a Ele o destino da vida e encontrar Nele o sentido da morte" (p. 151). O discurso a seguir confirma tais considerações:

Só ela mesmo e Deus para ajudar. Porque eu não sei o dia de amanhã não é verdade? O dia de amanhã é um dia difícil que a gente não sabe... Porque eu espero em Deus que não. Mas eu não sei te dizer nem sim, nem não. Por enquanto não... Agora, esperando em Deus o que ele há de fazer comigo, na minha idade. Peço que me dê saúde, que me dê força até o fim da vida. Meu Jesus, meu Deus, Espírito Santo, eu costumo dizer... Já não posso ir para a rua, fazer compras, nada disso. E já não saio sozinha na rua. Acho que eu não tenho mais, não espero mais nada. Eu espero que Êle me dê saúde, que Ele está me dando, pouquinha, mas hoje eu caio, mas amanhã eu levanto, vou para o médico hoje e amanhã eu já estou melhor. Estou bem, sabe, graças a Deus... (Id.5; Id.9; Id.10).

Este discurso reforça o que JOAN ERIKSON 1998 constatou: “...os anciãos são forçados a desconfiar das próprias capacidades. O tempo cobra um preço mesmo daqueles que foram sadios e capazes de manter músculos vigorosos e o corpo inevitavelmente enfraquece...” (p. 90).

Possuir condições físicas para continuar a se responsabilizar pelas atividades cotidianas de sua vida é o que os acalenta diante das inúmeras perdas que acompanham seu ciclo de vida. Novamente citamos GOLDSTEIN e SOMMERHALDER 2002 quando escrevem: “...a religião encoraja o indivíduo e promove a esperança de que, no fim, tudo estará bem" (p. 954).

Gostaríamos de também ponderar que neste discurso foi possível observar uma religiosidade marcante nesses idosos, o que não inviabiliza haver novas representações entre eles onde este fenômeno seja exatamente o oposto. A influência da religião e da espiritualidade na vida das pessoas idosas atualmente são questões pouco estudadas pela gerontologia. Ainda se tem um longo caminho a percorrer em pesquisas para mostrar que o vínculo entre envelhecimento/religiosidade/espiritualidade pode ser positivo e ajudar na vida das pessoas idosas. Seria necessário que os pesquisadores "sugerissem a direção dos ganhos propondo modelos para a compreensão desses resultados" (GOLDSTEIN e SOMMERHALDER, 2002, p. 955). 
Nos discursos pudemos também encontrar uma representação que nomeamos Não precisa, pois também tenho empregada, por ser uma estratégia de arranjo das famílias que possuem condições financeiras para a prestação do cuidado aos seus idosos. A presença deste profissional nos lares onde se encontram os idosos facilita em muito o convívio em família, pois as atividades do cuidado são divididas favorecendo que o cuidador familiar ocupe a função de coordenador e responsável pelo cuidado e pelo idoso, com mais liberdade em sua vida. Nossa experiência profissional no contato com essas famílias favoreceu perceber que as relações ficam mais amenas, visto que o cuidador familiar tem condições de preservar sua individualidade, de continuar a trabalhar, de ter uma vida mais desvinculada do idoso, tendo como resultado uma melhor relação com ele, sem prejuízo para ambos. Este tipo de arranjo familiar proporciona também um cuidado a distância que vários pesquisadores apontam como estratégia usada pelas famílias.

O cuidador profissional via de regra possui dupla função: fica responsável pelos trabalhos domésticos e também pelo cuidado ao idoso. Ao deparar com essa situação de cuidado iniciamos (nós e uma psicóloga do Centro de Saúde) trabalhos em grupos com cuidadores familiares e cuidadores profissionais, que na sua grande maioria eram empregadas domésticas. A experiência mostrou que o grupo ajudava a diminuir o estresse e possibilitava discutir as diferentes formas de olhar o cuidado aos idosos, proporcionando ainda uma troca de informações e de experiências vivenciadas por ambos, que favorecia a confiança e a cumplicidade, despertando nos cuidadores familiares a segurança de que poderiam entregar seus idosos aos cuidados de uma pessoa fora da família. A família fica amparada e livre da execução das atividades cotidianas tanto da casa quanto do idoso. Muitas vezes observamos que o cuidado flui melhor e todos saem ganhando. O cuidador familiar, ao se distanciar do cuidado pesado e desgastante, adquire mecanismos de compensação que ajudam grandemente a sua vida, impedindo que o idoso vá para uma instituição de longa permanência. Contar com o auxílio do empregado muitas vezes é fator preponderante para evitar o asilamento. 
Por enquanto não porque eu tenho (a minha empregada) que cuida muito bem de mim e é muito atenciosa em tudo...me ajuda a limpar a casa, a lavar, a passar porque sozinha eu não faço as coisas. Por exemplo, eu tomo banho sozinha, eu faço a comida, algum servicinho assim, eu faço, mas tudo, tudo, eu não posso fazer. Eu gosto de ficar na minha casa, gosto de sair, gosto de fazer as minhas compras, então isso eu gosto. E quando é assim, eu quero uma pessoa para ir junto comigo, não é verdade? Porque como eu estou desse jeito eu não posso sair sozinha. Agora, se por um acaso, Deus o livre, que ela não venha, aí o meu filho precisa perder dia de serviço. Mas até agora ele nunca perdeu dia de serviço, porque ele trabalha até de domingo. Trabalha de segunda a segunda. Mas eu estou muito bem. E depois, lá, ele telefona de vez em quando e diz "como é que está a minha mãe, como é que vocês estão aí, o que está acontecendo aí?" E tudo isso. Ele é muito bom pra mim. Ele arruma a minha cama... Ele faz tudo. Ele é um ótimo filho graças a Deus ele é muito bom. Graças a Deus não precisa de mais ninguém. Agora eu quero destacar também o carinho dela (empregada). Ela está sempre pronta, digamos, a me atender naquilo que eu preciso. Parece até que a gente tem assim uma linguagem do pensamento e quando eu penso ela já está lá pronta para atender. Então tudo isso são valores que a gente não pode esquecer. Eu estou no céu, tanto por ela como por ele, pelos dois. Eles me cuidam muito bem, e prestam muita atenção comigo e são muito atenciosos todos os dois, graças a Deus. E aí não precisou ele me pôr no asilo... (Id.8; Id.10; Id.17; Id.24)

Observamos neste discurso quão importante é esta figura para as famílias que possuem idosos fragilizados e parcialmente dependentes. Cada vez mais este profissional está sendo requisitado a prestar serviço nos lares. Fica aqui um alerta para a qualificação deste profissional, que deverá possuir aptidões e conhecimentos básicos de cuidado para uma população tão necessitada de ajuda. Há que se ter também atenção redobrada na contratação deste tipo de mão-de-obra para evitar negligência, maus-tratos e violência para com os idosos, que na maioria das vezes estão impossibilitados de se defenderem.

Diferentemente desta representação encontrada em nosso trabalho onde os idosos citam a importância da empregada doméstica, SANTOS 2003, em sua tese de doutorado sobre idosos demenciados e seus cuidadores familiares, diz que só foi possível identificar esta figura do empregado doméstico no trabalho de campo observando a existência do profissional e provocando o cuidador para falar sobre esta figura presente no domicílio. 
O discurso a seguir retrata uma situação de transição da independência para a gradativa dependência a que invariavelmente os idosos estão submetidos. Muito já se falou da autonomia e independência e de quanto estas capacidades são fundamentais para os seres humanos, acima de tudo para os idosos que experimentam perdas no seu cotidiano. O discurso que mostra a representação que denominamos Estaria morando sozinha caso não tivesse o cuidador familiar justifica a exposição clara dos motivos da perda gradativa. O sentimento de resignação perante a situação de fragilidade com comprometimento de sua segurança os convence a aceitar ajuda. Esta situação é muito comum e freqüentemente observada nos serviços de saúde. Assistimos ao pesar que estes idosos sentem quando precisam aceitar suas limitações e concordar em deixar sua casa e seus pertences para viver com outras pessoas na situação de dependentes. Este discurso mostra como o idoso que morava só e que estava parcialmente independente vivia o seu cotidiano construindo uma rede de suporte, que até o início da fragilidade satisfazia suas necessidades de vida. A partir de um evento de sua saúde é obrigado a repensar sua vida, e como possui respaldo familiar é assistido por ela. Vamos ao discurso:

Ah, não sei... Eu só sei que se não fosse essa dor no peito, e a hipoglicemia que começou a me dar eu estava morando sozinha até hoje. Eu passei numa médica, ela falou que por minha mentalidade, inteligência, eu teria condições de ficar sozinha, mas a minha filha falou que não, que não dava. O meu genro também falou "olha, a senhora não vai poder ficar sozinha mesmo, e se cai aí uma hora de noite, que vai no banheiro e cai. Vai ficar a noite toda aí, porque a senhora não vai conseguir chegar no telefone." Onde eu morava era sobrado, apesar de que eu tinha telefone em cima e embaixo, tinha extensão... eu tinha o telefone da venda, da farmácia, do açougue; eu já os conhecia, eu falava para o açougueiro, você me manda dois bifes?. Ele escolhia dois bifinhos bonitos e me mandava. A venda também eu pedia. Muito minha amiga a dona do mercado lá onde eu morava. Eu falava faz o favor de me mandar leite, pão, ou uma bengalinha de pão. O que eu precisava já me mandavam. Então, eu tinha um telefone, e como era meu eu ligava a hora que eu queria. Para as minhas amigas, tarde, ligava, elas me ligavam. Quando era dali a dois ou três dias eu tornava a dar retorno...Então tive que vir junto com ela mais eu nunca incomodei eles... Às vezes eu deixo dinheiro para ela, para comprar alguma coisa que precisa para pagar água, luz... ela fala "não, não quero mãe, não precisa, não... fica para pagar o remédio..." só essa semana de remédio foi 170 reais, só de dois três remedinhos... A minha filha e o meu genro fazem tudo, eles 
não sabem o que fazer mais ficam desesperados por causa dessa dor que eu tenho... Então não sei... (Id.3; Id.4).

Morar só é um fator de risco crucial para o indivíduo muito idoso e com incapacidades. A idade avançada contribui em muito para impedir o idoso de viver em sua casa autônomo e independente, porque ela é fator limitante para ele. Nos países mais desenvolvidos, além de suas características culturais é cada vez mais tardia a necessidade dos idosos de um acompanhamento supervisionado por parte da família, ou por uma instituição de longa permanência, porque sua condição econômica com seu alto padrão de vida, de saúde, e as políticas públicas são fatores favoráveis para mantê-lo independente por muito tempo. No Brasil este tipo de arranjo domiciliar começa a ser percebido através dos censos demográficos, que apontam o aumento do número de divórcios, de idosos solteiros e de viúvos, e também com a universalização dos benefícios da seguridade social. Uma das formas de conseguir manter o idoso em sua própria casa com segurança é a chamada "intimidade a distância," expressão utilizada primeiramente por pesquisadores internacionais e aqui no Brasil mais recentemente por nossos pesquisadores como Debert, Goldani, Camarano dentre outros, para enfatizar a autonomia e a satisfação pessoal que o idoso sente quando o responsável por ele administra o cuidado de uma forma mais livre, mantendo-o sob controle através de contatos por telefone ou visitas mais freqüentes. Este procedimento dá mais liberdade tanto ao idoso como ao cuidador, gerando satisfação em ambas as partes.

Do ponto de vista de GOLDANI 2004 “... diante da possibilidade de viverem separados, pais idosos e filhos adultos optariam por viver independentes, tal como sugere a crescente proporção dos arranjos domiciliares de pessoas que vivem sós" (p.234).

A representação que chamamos de Teria ajuda de amigos e do Centro de Saúde é tímida no sentido de pouca intensidade, ou baixamente compartilhada (termo referendado por Lefèvre e Lefèvre) pois apenas um idoso a mencionou. Esta ajuda é que os pesquisadores denominam de rede de suporte social onde também é reconhecida pelo idoso pelo seu significado de amparo, apoio caracterizando nesta visão como uma 
representação social. Foi uma experiência pessoal em que o suporte social dos amigos e do Centro de Saúde ajudaram o cuidador familiar e o idoso a encontrar outros recursos para o cuidado, fornecendo apoios tanto financeiro como de disponibilidade para fazer companhia a fim de que o cuidador pudesse trabalhar. Esta ajuda foi pontual e evitou, como ele próprio disse, “eu não precisei ficar internado.” Esta experiência e tantas outras que vivenciamos em nosso trabalho nos permitem dizer que quando os serviços sociais e de saúde ajudam esta dupla, amparando-a dando-lhe suporte psicológico e ajudando-a a encontrar o caminho que melhor satisfaça suas necessidades e dos seus idosos, os resultados são positivos para todos. Não defendemos aqui exclusivamente a família como única cuidadora, mas a possibilidade de discutir junto com as partes envolvidas diferentes possibilidades antes de tomar uma decisão definitiva, que na maioria das vezes se faz pela internação em instituição de longa permanência.

Uma rede de suporte social efetiva com comprometimento de todos auxilia em muito as famílias e seus cuidadores. As necessidades sociais e de saúde que os idosos apresentam oneram a família em todos os seus aspectos. O que comprovamos na prática e em relatos de pesquisas com depoimentos de cuidadores é que a ajuda de suporte para as famílias consiste em iniciativas próprias de determinados agrupamentos que encontram apoio da comunidade, como vizinhos, amigos, membros das igrejas. $\mathrm{O}$ discurso a seguir é exemplo disto:

Eu não precisei ser internada porque eu achei muita gente boa, graças a Deus, que me ajudou e me protegeu.... Os primeiros meses foi a assistente social quem pagou a menina que veio para cá... E eu fiquei muito bem. Depois, eu tinha muita visita... A minha amiga japonesa que ficou comigo uma semana... Ela vinha de manhã e ficava até a uma hora, me dava o almoço, almoçava e ficava comigo. Depois vinha a outra a uma hora e saía as seis horas.... Graças a Deus eu nunca fiquei sozinha... ( Id.8).

Diversas leis e medidas governamentais foram criadas a Política Nacional do Idoso, a Política de Saúde da Pessoa Idosa, o Estatuto do Idoso com o objetivo de proteção desta população contra a violência, a discriminação, etc. (GOLDANI, 2004). Contudo, as políticas públicas brasileiras não respondem às inúmeras necessidades dos idosos, mas o que podemos observar é um movimento de preocupação por parte das três 
esferas governamentais no sentido de priorizar esforços para responder às demandas desta população. Muito tem que ser feito para alcançarmos patamares dignos de atenção, onde os idosos e seus familiares possam ter seus direitos adquiridos. Por enquanto o que verificamos é que tanto os setores governamentais como a sociedade responsabilizam exclusivamente as famílias pelo cuidado aos idosos. No Brasil o discurso é de que os gastos são muito grandes para atender esta população, e que cabe à família a responsabilidade do cuidado aos seus membros mais vulneráveis. A própria Constituição de 1988, no seu artigo 230 considera: "responsabilidade da família, da sociedade e do Estado dar suporte aos idosos, assegurar sua participação na comunidade e defender sua dignidade e bem-estar, bem como garantir o seu direito à vida". O $1^{\circ}$ parágrafo deste artigo dispõe que "os programas de apoio para os idosos devem ser realizados, preferencialmente dentro de seus domicílios". Como reforça GOLDANI 2004 "a família para a Constituição é a grande provedora de cuidados para os idosos" (p. 224). Este fato possibilitou uma reação que SANTOS 2003 interpretou: "há um contra-movimento, ou seja, uma reprivatização do cuidado, que significa o retorno do cuidado ao contexto familiar... é como se houvesse uma redescoberta da dimensão afetiva, revalorização das relações domésticas e uma aceitação dos limites de intervenção bio-tecnológica e profissional, especialmente nos casos de doenças crônicas” (p.3). Mediante este cenário fica fácil entender o porquê de os idosos reconhecerem o valor de seus cuidadores familiares em sua vida.

\subsection{1 -Ancoragens}

Com esta política de valorização da família, delegando-lhe a responsabilidade do cuidado, e com medidas de proteção social deficiente e limitada os idosos na sua maioria atribuem à família a exclusividade do seu apoio. Neste panorama apresentaremos quatro ancoragens, que além de mostrarem a importância da família mostram a importância do papel de gênero no cuidado aos idosos. Denominamos estas ancoragens como: 
1. Filha cuida da família, da casa e dos pais;

2. Os filhos homens não cuidam bem dos pais;

3. Nora não cuida como filha;

4. Para a mulher cabe o serviço da casa e do cuidado e para o homem o cuidado das finanças.

Desde os primórdios da família como instituição cabe à mulher a tarefa de cuidar da casa, dos filhos e do companheiro. Ela representa o privado, o núcleo de relações, enfim, a família. O cuidado sempre foi atributo da figura feminina.

Quase todos os idosos entrevistados tinham nascido no início do século XX, quando o Brasil assistia à grande imigração de estrangeiros, mormente de italianos. STOLCKE, 1994. relata que "os fazendeiros paulistas convenceram o governo federal a incentivar a imigração para substituir os escravos nas fazendas de café ... e insistiram desde o início em contratar os trabalhadores em unidades familiares (p. 62). Estes imigrantes trouxeram sua cultura e influenciaram sobremaneira a cultura local. A importância da família e a ajuda mútua entre os seus membros era a cultura tanto dos fazendeiros quanto dos imigrantes. O trabalho era familiar, "reforçando sempre a solidariedade na família e a interdependência entre seus membros...Havia uma nítida separação de papéis por sexo e idade; mulheres e crianças estavam subordinadas ao chefe da família com relação à organização do trabalho" (idem, p. 73).

Com o fim do trabalho no campo e o início da industrialização nos grandes centros as relações sociais - pautadas na solidariedade - sofreram alterações e como diz STOLCKE 1994, "as relações sociais foram totalmente monetarizadas e ninguém tem o suficiente para dar aos outros" (p. 91). Mesmo nesse contexto, "espera-se que os filhos se encarreguem dos pais idosos... Criar filhos alheios juntamente com os próprios era muito freqüente; geralmente eram filhos de parentes mortos. Esta era uma obrigação moral, não obstante, também tinham implicações materiais..." (idem, p. 96). Em nosso trabalho há a presença de filhas adotivas como cuidadoras de seus idosos, confirmando os estudos. 
DEBERT 1999 evidencia que "o século XX testemunhou várias transformações na experiência do envelhecimento" (p. 55). A família sempre foi e é para esses idosos, além da unidade de cuidado, a unidade que acolhe e que provê suas necessidades.

CAMARANO e KANSO, 2003 reiteram: “...dada a predominância, em quase todo o mundo, de um modelo de políticas sociais que privilegia o enxugamento do Estado, as famílias estão sendo cada vez mais requeridas para cuidar dos seus segmentos vulneráveis..." (p. 2).

Cabe à figura feminina, principalmente a filha ou a esposa a tarefa de cuidar da casa e dos membros mais fragilizados. A preferência pela filha na prestação do cuidado é mencionada também por SAAD 2004, em seu estudo com idosos de Fortaleza. Os discursos de nossos idosos mostram claramente a divisão de tarefas para os homens e para as mulheres, dando ênfase ao cuidado da família exclusivamente pela figura feminina.

...É a filha, então desde sempre, por estar mais perto, tem que cuidar mais da gente. É a família da gente... ela é a responsável do serviço da casa... vai tudo na mão dela. Ela sabe como vai fazer, como há de fazer... (Id 20).

Ao homem cabe a responsabilidade do sustento, da manutenção e proteção da prole. Ele representa o público, o da rua.

...eu tenho a minha mulher que me cuida também... Ela também ajuda. Ela faz a comida, me dá tudo em ordem, a tempo. Isso eu não posso me queixar, porque ela é uma boa dona de casa... Ele (filho) também me ajuda faz muitas coisas... Ele é a minha mão direita aqui... Vou para cá, faço os meus recibos de inquilinos que eu tenho... E tenho mais liberdade com a pessoa de casa do que com pessoa de fora... Para falar e para fazer as coisas também... porque muitas vezes mexe com dinheiro, com uma coisa e outra...então tem mais confiança...(Id. 2).

SANCHÉS-AYÉNDES 1993, em seu estudo de Puerto Rico, encontrou semelhanças no que se refere ao papel das filhas na preferência tanto dos homens como das mulheres em idade avançada eles; "esperam que suas filhas ajudem no cuidado pois 
percebem que são mais compreensivas, confiáveis e mais capacitadas que os filhos para ajudá-los em seus problemas” (p. 288).

Os nossos idosos verbalizam isto de uma forma clara, quando não esperam dos filhos homens a prestação do cuidado:

...Porque os outros dois filhos, um está trabalhando em Santos, o outro trabalha também, e outra, são homens, não vai ficar cuidando da mãe... (Id. 16).

Outro fator impeditivo de cuidado executado pelos filhos homens refere-se à falta de confiança no cuidado desempenhado pelas noras. Nossos idosos mencionam como duvidoso esse trabalho se comparado ao das filhas. Não esperam nada das noras e focam toda a expectativa no cuidado desempenhado pelas filhas. Esta situação é verificada rotineiramente nos ambientes com a presença de idosos. A sobrecarga tanto das filhas quanto das esposas é visível nesses arranjos familiares. A verbalização dos idosos é interessante quando mencionam:

...Olha, para dizer a verdade, para ir para a casa dos meus filhos eu acho que não. Porque nora é diferente de filho, de filha. Acho que não tem o que falar... (Id. 27).

CAMARANO et al. 2004 também mencionam outros estudos brasileiros onde as filhas são as eleitas para o cuidado: "foi observada uma preferência das mães em morarem na casa das filhas... As expectativas da população idosa eram de morar com filhas e não com filhos" (p. 145).

Os estudos mostram as preferências dos idosos para com suas filhas e observamos cada vez mais estas mulheres se esquivando da função do cuidado por necessidades financeiras, e até mesmo por aspirações pessoais de sucesso na vida profissional e sentimental. Participar do mercado de trabalho e da competição acirrada é inversamente proporcional ao cuidado aos membros mais vulneráveis.

A expectativa da sociedade e dos idosos para que a mulher assuma a tarefa do cuidado é muito comum nas unidades familiares, sociais e de saúde, proporcionando uma tensão e uma cobrança por parte de todos. 
GOLDANI 2004 pondera que “...até hoje, as mulheres têm sido as principais cuidadoras das crianças e dos idosos, realizando as tarefas rotineiras e dando coesão às relações entre as gerações. Os homens e as mulheres brasileiros têm direitos iguais perante a lei, mas, no que diz respeito ao cuidado dos dependentes nossas normas culturais ainda refletem uma expectativa maior sobre as mulheres do que sobre os homens" (p. 239).

Os cuidadores e suas famílias necessitam verdadeiramente de parceiros competentes para o auxílio no cuidado de seus idosos. CAMARANO et al. 2004 citando os arranjos familiares em uma perspectiva internacional, verificam que nos países como: Alemanha, Canadá, Japão, Reino Unido e USA os familiares, principalmente os filhos, reconhecem seu papel de cuidar de seus velhos. Conforme comentário das autoras, "1/3 dos jovens europeus acredita que sua geração tem responsabilidades para com seus idosos..." ( p. 143).

A diferença que verificamos nesses países é que estes idosos e seus filhos possuem o respaldo de políticas sociais direcionadas às populações mais vulneráveis.

Todos os dias assistímos à terrível situação de idosos que não possuem respaldo familiar para auxílio de suas necessidades. O quadro é pintado em cores muito negras e assustadoras, sem nenhuma condição de dignidade humana.

O aumento de pessoas idosas nesta condição está alarmante e visível a todos, com medidas sociais muitas vezes desconectadas, ineficazes e ineficientes de amparo.

A velhice e suas implicações para os cidadãos brasileiros é um grande desafio para o Estado, que parece caminhar devagar na sua função de proporcionar condições sociais, de saúde, de lazer, de justiça, entre outras, para o bem-estar dessa população que a cada dia cresce, contando apenas com as soluções que seus familiares encontram para o desempenho do cuidado. Para aqueles indivíduos que não possuem tal respaldo cabe apenas contar com a boa vontade de amigos, vizinhos e também de Deus, como disseram alguns idosos de nosso estudo. 


\subsection{OBSERVAÇÕES SOBRE A EXPERIÊNCIA DE ABORDAGEM COM OS IDOSOS ENTREVISTADOS}

Após a etapa do pré-teste e com o instrumento adequado, demos início ao trabalho de campo em 31 de janeiro de 2005. Respeitando os critérios de exclusão (mencionados anteriormente na metodologia), iniciamos a investigação para a escolha dos idosos, para compor o universo da pesquisa através da coleta de informações do prontuário, do contato com o cuidador e do contato com os demais profissionais do serviço.

Vale salientar que a composição da amostra foi intencional, baseada nos pressupostos metodológicos de LEFÈVRE et al. (2000). Identificado o idoso, fazíamos o contato primeiramente com seu cuidador, no próprio CSE no momento da consulta do idoso, ou através de contato telefônico, com o objetivo de obter sua aprovação para estar entrevistando o seu familiar e para explicar-lhe os objetivos do trabalho, como seria a condução da entrevista e o local onde seria realizada. Esta consulta ao cuidador foi uma medida de extrema importância para que a pesquisa pudesse se concretizar, pois acreditamos que com isto seria possível estabelecer uma relação de confiança entre o pesquisador e o cuidador, elemento-chave para chegar ao idoso.

Vencida essa etapa e somente após a permissão dos cuidadores foi feito o contato com os idosos, quando também foram explicados os objetivos da pesquisa, como seria conduzida, e também foi solicitada a sua autorização para a participação e gravação da entrevista. Como os idosos possuíam pequenas dependências e sua autonomia estava preservada, a obtenção do seu consentimento era de suma importância para o prosseguimento da exploração do trabalho de campo. Pudemos observar que em muitos casos era o incentivo do cuidador que favorecia a participação do idoso na pesquisa.

Outro fato que merece ser destacado é que o acesso ao idoso e a seu cuidador foi facilitado porque ambos conheciam o trabalho da pesquisadora no CSE, o que influenciou muito a sua adesão, sendo possível abordar com tranqüilidade o assunto pesquisado. Somente com o consentimento do idoso e do cuidador familiar é que foi 
marcada a visita no domicílio no melhor dia e horário, respeitando as necessidades e desejos de ambos. A escolha do domicílio como local da pesquisa se deu pelo fato de ser mais fácil para o idoso, e para o seu cuidador, considerando-se as fragilidades e dependências que dificultariam a locomoção do idoso, e também por acreditar que em sua casa ele teria mais liberdade para expressar-se e sentiria mais segurança em falar sobre o assunto. Apenas dois idosos preferiram fazer a entrevista no CSE, e foi respeitada a sua vontade.

No domicilio os maiores desafios foram: quebrar o constrangimento da pesquisadora de estar abordando o assunto, principalmente nas primeiras entrevistas; preencher os dados de identificação do idoso; preencher o instrumento da escala de avaliação funcional; solicitar a assinatura do termo de consentimento; e, por fim, a execução do teste o`clock, que para muitos foi um fator estressante e de grande dificuldade para a sua confecção. Quanto à questão do constrangimento da pesquisadora, gostaríamos de comentar que no início da pesquisa houve um sentimento de incômodo e de dificuldade por estar abordando de forma tão direta a questão da importância do cuidador na vida do idoso, em especial no seu contexto de vida e de cuidado, com questões bastante delicadas sobre sua vida. Nossa surpresa, e o que nos ajudou a superar esse constrangimento foi como os idosos reagiram no final de cada entrevista, quando era solicitado como medida de avaliação o seu comentário concernente à entrevista e como se sentiam ao falar sobre o tema. A avaliação era sempre positiva, sem manifestar constrangimento e invasão. Uma idosa que se sentiu incomodada no início da entrevista, ao final, em seu comentário expressou sua satisfação em falar sobre o assunto. Com os retornos dos idosos e com o transcorrer da pesquisa, este sentimento de intrusão foi se diluindo e com isto fomos vencendo esse desafio pessoal.

Como os idosos na sua maioria possuíam idades acima de 75 anos e pouca escolaridade, para alguns o fato de terem que assinar o termo de consentimento causou stress porque tinham dificuldade em assinar o documento, por falta de destreza, por timidez, ou por analfabetismo. Os idosos com mais escolaridade não se estressaram na assinatura do termo. 
O preenchimento dos dados de identificação (para compor o perfil dos idosos e de sua família (Anexo 4) e da escala de avaliação funcional (para avaliar a capacidade funcional dos idosos (Anexo 5) tomava algum tempo dos idosos causando-lhes apreensão sobretudo quando tinham que escolher entre as alternativas propostas. O teste óclock (para rastreamento de alterações cognitivas (Anexo 3) não se mostrou muito adequado para essa população, pois seus membros eram bem idosos, com pouca escolaridade (1 - 4 anos) e num limiar de fragilidade que os impedia de executar facilmente o teste, e quando o faziam muitos apresentaram resultados alterados de acordo com o padrão estabelecido. Autores como FUZIKAWA, 2002 e LOURENÇO et al. 2003, também questionam o seu uso em idosos com pouca escolaridade, sugerindo maiores investigações. Durante a análise dos dados da pesquisa fizemos a opção de não considerar o teste baseado nas ponderações desses autores, e também pelo conteúdo dos discursos dos idosos que se mostraram coerentes e ricos em significados e representações. A riqueza dos depoimentos está registrada nos resultados e na discussão. A presença do gravador não foi fator gerador nem de constrangimento e nem de stress para os idosos. Apenas um deles que se recusou a dar entrevista referiu como impedimento o gravador. Todas as entrevistas foram feitas pela pesquisadora e a média de permanência no domicílio foi de aproximadamente 2 horas. A necessidade desta permanência foi para que se pudesse obter um ambiente tranqüilo durante a entrevista, e que o idoso tivesse tranqüilidade e confiança para falar sobre sua vida, seus anseios e sobretudo o que achasse importante falar sobre o cuidador e sua família, e também para o preenchimento de todos os instrumentos. O assunto abordado era delicado para eles, pois o que era solicitado envolvia sentimentos, história de vida, relacionamentos, cuidado, disponibilidades de ambos para a convivência diária, conflitos, etc.

O tempo e a descontração foram aliados da pesquisadora.

Evitar o constrangimento e situações de desconforto por parte dos idosos foi uma constante nas visitas. Verificamos desde a primeira entrevista que o tempo anterior à gravação era fundamental como aquecimento para as entrevistas propriamente ditas, que em média duravam 10 minutos. 
A gravação era anunciada e novamente era dada a possibilidade de desistência caso o idoso se sentisse constrangido. Houve apenas uma recusa.

Um outro fato que merece ser destacado é que foi solicitado ao cuidador que permanecesse no domicílio no momento da entrevista, mas foi-lhe dito que a entrevista seria mais proveitosa se fosse apenas com o idoso, sem a sua presença para evitar algum viés ou constrangimentos, pelo fato de que ele, cuidador, era o sujeito principal mencionado na entrevista. Em duas entrevistas isto não foi possível.

Durante o processo do trabalho de campo e analisando os depoimentos pudemos perceber e constatar que o cuidador é o elemento-chave entre os serviços e o idoso. É ele quem abre as portas da casa e o acesso ao idoso. Ele possui o poder de decisão do cuidado, o controle da vida cotidiana do idoso, mas muitas vezes não controla sua vontade e sua autonomia. Por maior que seja o conflito, é através desse cuidador que os serviços - sejam sociais ou de saúde - chegam a esse idoso. 


\section{CONCLUSÕES}

Através dos discursos dos idosos pudemos conhecer o universo das relações de cuidados com seus familiares cuidadores. Para eles o cuidado desempenhado tem vários significados.

O afeto foi um componente fundamental mencionado por eles. Era imprescindível para o cuidado. Ele vinha acompanhado de dedicação, de preocupação, de atenção, e muitas vezes de sacrifício.

A obrigação/retribuição possuiu dois significados diferentes: o primeiro tinha um caráter natural da obrigação/retribuição deste cuidado onde justificavam serem merecedores de cuidados porque o fizeram quando podiam e quando foi necessário e solicitado; o segundo tratava-se de uma expectativa de comportamento em relação ao cuidador familiar quando os idosos exigiam a cobrança do cuidado principalmente por parte dos filhos. $\mathrm{O}$ fato de serem pais lhes dava o direito de receber e obrigar os filhos a cuidarem deles na velhice.

A tensão e o desgaste foram mencionados e percebidos pelos idosos onde pudemos verificar que eles muitas vezes lamentavam e aceitavam as imposições de seus cuidadores.

A constatação da vocação para o cuidado também pode ser identificada nos depoimentos dos idosos. Eles reconheceram os cuidadores que sempre estiveram disponíveis para o cuidado.

A solidão que sentiam no seu cotidiano de vida com seus cuidadores foi uma representação mencionada quando relatavam as dificuldades que enfrentavam sozinhos quando o cuidador precisava se ausentar por necessidades de trabalho ou mesmo para ter um pouco de privacidade. O discurso possibilitou avaliar quão difícil é envelhecer e quanto é temível a sombra da incapacidade.

A troca de papéis na relação de cuidados é também muito mencionada pelos estudiosos e foi encontrada nos discursos dos idosos. O diálogo franco e aberto 
possibilitou a harmonia entre eles favorecendo a reflexão de uma nova experiência de cuidados e interação entre eles.

Quanto ao significado da importância do cuidador familiar a competência do mesmo foi uma representação que teve um peso importante sendo altamente compartilhada no universo pesquisado. Para os idosos, seus cuidadores eram competentes porque: eram cuidadosos, calmos, confiáveis, atendiam-nos, em suas atividades cotidianas, possuíam conhecimentos técnicos. Sentiam-se protegidos e confiantes do cuidado que eles prestavam.

Outra manifestação da importância destes cuidadores pode ser verificada em duas representações encontradas que foram nomeadas Seria difícil, pois não tenho ninguém onde referiram o valor dos mesmos não apontando outra alternativa que não fosse ficar sozinhos. Não reconheceram outros cuidadores. A outra forma de expressão de sua importância pode ser observada no discurso Eu só tenho ele para cuidar de mim onde presenciamos através da fala dos idosos o fenômeno referendado pelos demógrafos e estudiosos do envelhecimento quando constatam os cônjuges idosos cuidando de seus parceiros idosos. A responsabilidade pelo cuidado fica exclusivamente voltada para o cônjuge que conta com pouca ajuda dos filhos ou de outra pessoa.

A presença da dependência física (não a cognitiva, pois é muito pior) foi fator de reconhecimento da importância dos cuidadores quando os idosos referiram Sou dependente preciso dele. Esta dependência foi fator impeditivo do autocuidado, das AVD e AIVD para os idosos necessitando que outras pessoas ajudassem no cuidado pois não eram capazes de executar sozinhos. A dependência do idoso e suas implicações para a vida de seus cuidadores são exaustivamente referidas nos trabalhos acadêmicos. Os nossos idosos também reconheceram o quanto fica difícil para ambos o cotidiano de cuidados quando são severamente dependentes.

A representação Sou objeto fácil para o cuidado, pois sou independente mostrou também a importância do cuidador na medida que os idosos justificaram que também faziam sua parte tentando agradar e poupar o cuidador de aborrecimentos e 
contrariedades. A descrição de suas habilidades e competências foram mencionadas como fundamentais para o desempenho de suas atividades cotidianas de cuidado.

O reconhecimento da importância da família ficou explicitado na representação Tenho minha família quando verificamos que no imaginário dos idosos na hipótese de não haver mais o cuidador principal haveria outros familiares para lhes prestar ajuda proporcionando uma rede de suporte para eles. A presença de outros membros familiares foi mencionada com bastante ênfase pelos idosos. Reconheceram a importância do convívio e as trocas intergeracionais entre eles.

Os idosos apontaram algumas alternativas para o cuidado na hipótese de não haver mais o cuidador familiar: encontrar outro cuidador; ir para uma instituição de longa permanência; contratar uma empregada doméstica; contar com a ajuda de Deus; morar sozinho; contar com a ajuda da rede de suporte social.

Foi também possível encontrar nos discursos, através das ancoragens Filha cuida da família, e dos pais; Os filhos homens não cuidam bem dos pais; Nora não cuida como filha; Para a mulher cabe o serviço da casa e do cuidado e para o homem o cuidado das finanças, a importância do papel de gênero no cuidado aos idosos. A preferência pela filha e pela esposa foi veementemente referenciada.

Pudemos depreender dos discursos de nossos idosos a busca contínua da liberdade de escolha para uma sobrevivência autônoma e digna.

Foi possível também extrair o cotidiano de cuidados entre eles e como se estabeleceram estas relações de cuidados. 


\section{CONSIDERAÇÕES FINAIS}

No Brasil o envelhecimento é um tema recente de discussão porque até poucas décadas éramos um país jovem. Atualmente os meios de comunicação estão se empenhando em mostrar uma velhice saudável, com qualidade de vida, e muitas vezes diferente da realidade de muitos idosos brasileiros. Os estudiosos do envelhecimento alertam para as implicações que este fenômeno acarretará para a sociedade, com seus desdobramentos tanto de saúde como da seguridade social, de economia, lazer e turismo, de educação, quando vislumbram um cenário preocupante. Medidas eficazes para acolher esta camada crescente da população brasileira serão bem-vindas e se fazem necessárias.

Outro lado da moeda do envelhecimento, mais problemático, trata daqueles idosos que estão fragilizados pelas doenças decorrentes da idade, que necessitam de cuidados, e daqueles que sofreram agravos sérios de saúde tornando-se dependentes e onerosos para a família e para o Estado.

No Brasil, como nos demais países latino-americanos, o cuidado com os elementos mais vulneráveis fica principalmente restrito ao âmbito familiar, e por isto, pesquisar o que pensa o idoso fragilizado sobre o seu cuidador familiar, e como se estabelecem as relações de cuidado nesta díade foi o objetivo deste estudo.

A riqueza dos discursos proporcionou entrar no universo de cuidados familiares pela ótica dos idosos. O que verificamos foi que através destes discursos os idosos que se encontravam na condição de receptores dos cuidados puderam mencionar fatos, acontecimentos e situações cotidianas de sua vida e da de seus cuidadores. Cabe aqui citar o que DEBRET (1999) diz: "A velhice é retratada de maneira distinta em função do tipo de interação focalizada. Pensar na relação entre o idoso e a família é ora fazer um retrato trágico da experiência de envelhecimento, ora minimizar o conjunto de transformações ocorridas nas relações familiares" (p. 55).

A legitimidade das falas fica evidente na medida em que os idosos de uma forma simples e natural enumeram suas atividades e atitudes, como também de seus 
cuidadores, que julgam ser importantes para a sua vida nos momentos em que necessitam de ajuda para continuar vivendo.

A emoção muitas vezes percebida ocorreu por se tratar de pesquisa qualitativa, e ter como análise dos dados o Discurso do Sujeito Coletivo - DSC -, que possibilitou fazer emergir as representações dos idosos através dos discursos, respeitando sua fidedignidade sem prejuízo do conteúdo.

Com a técnica do DSC foi possível trazer à luz seus pensamentos, idéias, conceitos, crenças e atitudes.

Como explicitam LEFÈVRE e LEFÈVRE 2005, “...por ser um discurso, por constituir uma cadeia argumentativa e pelo discurso estar enunciado na primeira pessoa, em termos peirceanos, acaba constituindo um poderoso interpretante para estas representações na medida em que viabiliza metodologicamente o acesso a elas tornandoas claras e explícitas, e também porque potencializa sua comunicabilidade e seu impacto nos receptores"(p. 35).

Os idosos entrevistados eram em média muito idosos, mulheres na sua maioria, tinham pouca escolaridade, apresentavam doenças crônicas do tipo hipertensão, diabetes, problemas oculares e de audição, problemas cardíacos, ou seja, possuíam incapacidades para realizar Atividades Instrumentais de Vida Diária (AIVDs), e alguns para as Atividades de Vida Diária (AVDs). Muitos tiveram dificuldade em realizar o teste o`clock o que não os impediu de mostrar suas capacidades emocionais e cognitivas, em nomear suas virtudes e potencialidades, e também em superar as dificuldades cotidianas de vida que em geral eram mencionadas de forma contundente e realista.

$\mathrm{O}$ fato de terem rendimentos do tipo poupança ou pensão deixava-os em situação confortável perante suas famílias.

A lucidez desses idosos em enumerar e justificar seus pontos de vista, seus valores, suas crenças, seu modo de ver o mundo, nos alerta de quanto ainda temos que caminhar na construção de políticas públicas eficazes que realcem medidas protetoras de atenção à população idosa e suas famílias, e por extensão aos cuidadores. Com estas representações tão ricas em significados tivemos a oportunidade de conhecer suas 
alegrias e temores, a importância da família e a necessidade de um cuidador para os idosos fragilizados.

A presença maciça da figura feminina na posição de filhas ou esposas como cuidadoras não se diferenciou de todos os estudos sobre o assunto.

A importância dos cuidadores e da família para os idosos está exaustivamente presente em seus discursos. Para aqueles do nosso trabalho a família é o seu maior bem. Seu reconhecimento sobre esta instituição está fortemente registrado nos discursos de maneira clara e precisa. A família aparece bem caracterizada nas três questões elaboradas e em uma ancoragem demonstrando a força da sua representação.

Ao nos aprofundarmos no universo dos idosos pudemos perceber que possuíam uma nítida percepção das dificuldades da prestação do cuidado para a vida de seu familiar. Percebiam e tinham noção da sua importância, com a certeza de que sem eles provavelmente seria muito difícil encontrar outro para assumir tal responsabilidade.

Ao lermos os discursos temos a possibilidade de observar a força que esses idosos fazem para preservar sua autonomia e independência. A importância da realização das atividades de vida diária é a última manifestação de controle de sua capacidade de independência. O temor de depender totalmente de seus cuidadores é penoso para eles e expressado de modo muito singular. As diferentes alternativas de cuidado, na ausência do cuidador, são mencionadas de modo interessante e realista.

O reconhecimento da perda gradativa da autonomia, com a enumeração de capacidades que ainda estão preservadas, nos possibilita imaginar como é difícil conviver com essas perdas e deficiências, compreendendo a razão de tamanho desgaste e tensão para eles.

Ser alvo do cuidado e necessitar do cuidador para sobreviver é percebido e valorizado por eles, e expressado no momento em que reconhecem quanto o cuidador é imprescindível. Este reconhecimento está documentado pela maioria dos idosos (23) quando enumeram a competência e eficácia do cuidador em realizar o cuidado. Também vemos essa importância quando reconhecem só terem esse cuidador e mais ninguém para cuidar deles. 
Um fato interessante observado também foi quando relativizam o cuidado, considerando que cuidar deles é fácil, pois não dão muito trabalho e ainda são independentes. Foi possível entrever nos discursos a oposição de independência e dependência, quando mostramos a apreensão dos idosos ao reconhecerem suas deficiências. A compreensão de que o cuidado acarreta dificuldades para os cuidadores é percebida no momento que têm a noção de que outros meios poderão ser acionados caso o cuidador não possa mais exercer o cuidado. As possibilidades apontadas pelos idosos são variadas: casa de repouso, outro cuidador, Deus, morar só, suporte de amigos e do Centro de Saúde.

A presença marcante do empregado doméstico que em muito auxilia as famílias e sobretudo o cuidador, merece ser ressaltada. Contar com este sujeito nos domicílios é um fator decisivo para a manutenção do idoso em sua casa junto com seus familiares. A sombra do asilamento é temível, fato verificado em seus discursos.

Os sentimentos que os cuidadores despertam nos idosos são quase sempre positivos, malgrado às vezes sejam permeados de desgaste e tensão. $\mathrm{O}$ afeto que sentem e recebem de seus familiares é valorizado e considerado. A consciência da reciprocidade entre os membros da família é algo incontestável e natural, como notamos nos discursos esclarecedores. A solidão foi uma representação que apareceu nesta pesquisa, e nos permite entender como é dolorosa para os idosos. Embora o idoso possua cuidador, a falta de uma companhia desperta nele um sentimento de abandono. O conteúdo do discurso é perturbador e rico de significado, possibilitando uma reflexão sobre o sentido da velhice e suas conseqüências, geralmente acompanhada de importantes perdas pessoais (autonomia e independência) e de relações (cônjuge, amigos, parentes).

A extensa literatura sobre cuidadores de idosos dependentes ou fragilizados, com a enumeração das dificuldades no trabalho cotidiano e as variadas representações encontradas no significado do cuidado prestado por eles confrontada com as representações que os idosos têm sobre o que significa este cuidado, poderá servir como norteadora de políticas de amparo a esta díade no sentido de protegê-la com estratégias de suporte como: melhoria do acesso desta população aos serviços sociais e de saúde; 
criação de centros-dia de atendimento, lazer e cultura; expansão e acesso a atendimentos especializados, como fisioterapia, odontologia, exames complementares, psicologia, nutrição, fonoaudiologia, e principalmente acesso aos hospitais na necessidade de uma possível internação, com o direito de ser atendido com dignidade. Ainda no Brasil a única alternativa de atendimento de saúde para muitos idosos são os prontos-socorros dos hospitais públicos, onde em geral é prestado um atendimento desumano e ineficiente, por incapacidade do sistema de amparo tanto social como de políticas públicas.

O fenômeno do envelhecimento populacional é mundial e os países desenvolvidos possuem mecanismos de proteção a esta população mais eficazes que os países em desenvolvimento, mas a unanimidade em todas as recomendações mundiais dos órgãos internacionais que ditam as diretrizes das políticas para esta faixa etária é a importância do papel da família no cuidado dessas pessoas. O reconhecimento desse parceiro fica explícito em todas as recomendações desses órgãos quando justificam ser inviável o custeio financeiro, de recursos humanos, internações a cargo do poder público exclusivamente, para o atendimento digno e qualificado dessa população.

O desafio do Brasil neste século XXI será o de lidar com este crescente contingente de seres humanos num contexto social e de saúde desigual, com políticas públicas excludentes e desumanas.

As dificuldades em se concretizar as diretrizes básicas do Sistema Único de Saúde (SUS) - que é o grande norteador das políticas públicas brasileiras - intensificam mais a problemática da assistência à população idosa. No momento em que o modelo de atenção à saúde não considera a promoção e a prevenção no atendimento voltado a esta camada da população, os resultados ficam aquém do esperado. Sabemos que este segmento da sociedade é possuidor de muitas demandas sociais, de saúde, de seguridade social, de lazer, e mesmo de economia que, uma vez ausentes ou ineficazes, geram grandes dificuldades tanto para os idosos quanto para suas famílias.

Estando os idosos e suas famílias desamparados num contexto tão adverso, resta apenas o conformismo e a aceitação em prestar o cuidado como podem. 
Os depoimentos dos idosos nos mostram um universo pessoal, no qual, apesar de suas fragilidades e da necessidade de ajuda para suas atividades cotidianas, possuem vontade própria, desejos, esperança de um futuro junto aos seus membros familiares.

Resta agora perguntar como fica o cuidado desta população num contexto onde estão em jogo atores como a família, o Estado, a iniciativa privada e a sociedade?

A família, vivenciando uma crise onde cada vez mais a mulher se distancia da função de cuidadora de seus membros; o Estado, não assumindo mais seu papel de gestor das políticas públicas, cuja função é formular e criar medidas de proteção aos segmentos mais vulneráveis da população; a iniciativa privada, já vislumbrando lucro neste vácuo que não está sendo preenchido, posicionando-se com medidas de caráter estritamente curativo, oferecendo alta tecnologia de cuidado tanto hospitalar como domiciliar, com a manutenção do paradigma de medicina intervencionista centrada na construção de hospitais para a terceira idade com sofisticadas instalações; e, por fim, compondo este cenário, a sociedade, que não quer discutir a questão da velhice e suas implicações, preferindo acreditar na juventude eterna que os meios de comunicação exaustivamente apregoam, vendendo uma falsa noção de felicidade centrada no corpo musculoso, jovem, a qualquer custo.

Nesse contexto, a velhice e suas fragilidades são veementemente rechaçadas e ignoradas. O indivíduo velho é "o outro que não faz parte de mim”.

Na verdade, a cultura brasileira atual está centrada no consumo exagerado e num estilo de vida individual e egoísta, onde o que é valorizado é o bem-estar próprio. Não se valoriza mais a generosidade entre as gerações. O que se verifica é o que DEBERT 1999 mostra: "impõe-se novo estilo de vida criando uma série de regras de comportamento e de consumo de bens específicos que indicam como aqueles que não se sentem velhos devem proceder" (p. 213).

Neste cenário a família encontra-se sozinha com a obrigação de cuidar de seus idosos, comprometendo todos os seus membros, e muitas vezes sem suporte nenhum para desenvolver o cuidado, e o que verificamos é um jogo de empurra onde cada um quer se esquivar do problema, comprometendo o cuidado ao idoso. 
De fato, exercer o cuidado na maioria das vezes é desgastante e despende muita energia, tempo e disposição para o seu exercício, sendo a figura feminina desde os tempos remotos atrelada ao cuidado dos membros mais vulneráveis da família. Ora, o novo papel da mulher na competição do mercado de trabalho e as suas aspirações, sonhos de realização profissional e sexual estão distanciando-a deste papel tradicional. Todos os dias assistimos ao conflito a que estão submetidas quando são chamadas a exercer o papel que toda a família e a sociedade esperam dela, embora nas classes menos privilegiadas este movimento de encontrar um cuidador pareça menos problemático nas famílias com pequenos rendimentos a solidariedade parece estar mais presente, pois não contam com outros recursos a não ser o respaldo familiar.

O cuidado é um tema intrigante e propicia caloroso debate entre os estudiosos do envelhecimento porque é ponto central da díade idoso - cuidador familiar.

É através do cuidado que o homem é dignificado na sua condição de Ser Humano, e sem ele transforma-se em ser amorfo, sem significado, sem identidade, sem valor, sem dignidade. Precisamos dele para ser respeitados e ter a certeza de que valeu ter vivido, e que nossa história valeu para alguma coisa. Através dele sentimos o calor de um abraço, de um olhar afetuoso, de um sorriso, de um falar carinhoso e acolhedor, enfim, de um aconchego que nos acalente quando precisarmos para sentir que estamos vivos.

Por outro lado, sabemos também que esse cuidado é muito desgastante e estressante, principalmente quando se trata de idosos com severas dependências. Após ouvirmos os discursos dos idosos, alguns dados ficam claros: sua luta obstinada em manter sua autonomia, mesmo apresentando dependências físicas, está fortemente presente; o cuidado a um indivíduo frágil por si só acarreta desgaste e desconforto ao cuidador, pois este deverá abdicar de sua vida em detrimento do outro; este novo papel para o cuidador causa-lhes transtornos pessoais, profissionais, físicos e mentais; o trabalho solitário do cuidado, que é uma constante nas famílias, gera sensação de desânimo e impotência diante da vida. 
Mas é o cuidado dispensado aos idosos que dignifica a sua existência. Esta dignidade para eles está intimamente relacionada ao tipo de cuidado que recebem, seja da família, de profissionais, de amigos, ou mesmo de instituições. O que verificamos neste estudo é que para os idosos a família é a grande escolhida para fornecer-lhes o cuidado de que necessitam.

Sendo assim, é oportuno reproduzirmos o que SANCHES, 2000 diz: “...a convivência satisfatória e o bem-estar da pessoa que envelhece em condição de fragilidade demandam que os arranjos familiares se constituam por valores construídos por seus integrantes entre os quais se inclui os idosos" (p. 51).

O impasse fica então claro, e a exposição detalhada de necessidades, anseios, desejos de ambas as partes nos leva à reflexão do que é envelhecer num contexto social e cultural tão adverso como o nosso.

Assim, acreditamos que o início deste árduo trabalho esteja na reeducação das gerações que virão com o objetivo de olhar com outra ótica a velhice e o idoso, nas suas diferentes facetas. A nova geração de profissionais - de qualquer profissão - deverá ser sensibilizada para que possa exercer suas funções com mais respeito a essas pessoas que muito contribuíram para suas famílias e para o Brasil.

Pesquisa nacional recente do DataFolha (outubro 2007) aponta que para os brasileiros a família é a instituição mais valorizada no País. Podemos questionar os dados da pesquisa quanto às questões metodológicas, ideológicas, de mídia, etc., mas não podemos negar que de maneira geral eles refletem a opinião do povo. Sobre esta mesma pesquisa, Camarano e Mello argumentam que há diferença entre a valorização da importância da família para as mulheres das classes mais abastadas e para as mais pobres, sendo o valor maior para as primeiras.

Não pretendemos aqui fazer uma apologia à família, mas não podemos negar que ela para o idoso e para as pessoas vulneráveis é um decisivo respaldo. Neste sentido, estamos presenciando um movimento em congressos e na sociedade, com debates discutindo esta problemática e constatando a necessidade do retorno do cuidado no 
âmbito familiar, como medida urgente para a prestação de cuidados aos idosos, com propostas de acompanhamento monitorado, tanto para o idoso como para seu familiar.

Ao final deste trabalho ficam algumas perguntas inquietantes:

Como idosos brasileiros no século XXI, seremos valorizados e respeitados pela sociedade em nossas deficiências e incapacidades? As políticas públicas serão eficientes para nos proteger caso estejamos sozinhos? Se tivermos uma família, seremos competentes para criar adequadas relações afetivas com nossos familiares?

As respostas a estes questionamentos merecem ser refletidas individualmente, e também nos debates políticos, fóruns, encontros acadêmicos, seminários e no Congresso Nacional, nas Assembléias Estaduais e nas Câmaras Municipais.

A velhice, o envelhecimento e seus desdobramentos são temas que devem merecer ampla discussão envolvendo toda a sociedade, com o propósito de urgentemente encontrar soluções práticas para a resolução de suas implicações na vida de todos os brasileiros. CAMARANO e PASINATO 2004 aconselham: "As políticas para a população idosa devem promover a solidariedade entre as gerações. Isto significa equilibrar as prioridades das necessidades dos idosos com a de outros grupos populacionais" (p. 288).

O envelhecimento, portanto, importa a todos nós. 


\section{REFERÊNCIAS}

Abric JC. A abordagem estrutural das representações sociais. In: Moreira ASP, Oliveira DC, organizadoras. Estudos interdisciplinares de representação social. 2. ed. Goiânia: AB Editora; 2000. p. 27-38.

Almeida AMO, Cunha GG. Representações sociais do desenvolvimento humano. Psicol Reflex Crit. 2003; 16(1):147-55.

Andrade OG. Suporte ao sistema de cuidado familiar do idoso com AVC a partir de uma perspectiva holística de saúde [tese de doutorado]. Ribeirão Preto: Escola de Enfermagem da USP; 2001.

Angelo M. O contexto familiar. In: Duarte YAO, Diogo MJDE, organizadores. Atendimento domiciliário: um enfoque gerontológico. São Paulo: Atheneu; 2000. p.2731.

Aquino FTM, Cabral BES. O idoso e a família. In: Freitas EV, Py L, Néri AL, Cançado FAX, Gorzoni ML, Rocha SM. Tratado de geriatria e gerontologia. Rio de Janeiro: Guanabara; 2002. p.1056-60.

Arantes AA, Bianco BF, Brandão CR, Correia M, Slenes R, Kofes S, Stolcke V. Colcha de retalhos: estudos sobre a família no Brasil. 3. ed. Campinas: Ed. Unicamp; 1994.

Arruda A. Teoria das representações sociais e teorias de gênero. Cad Pesq. 2002; (117):127-47.

Ayéndes-Sanches M. La mujer como provedora principal de apoyo a los ancianos: el caso de Puerto Rico. In: Goméz-Goméz E, editor Gênero, mujer y salud en las Américas. Washington (DC): OPS; 1993. p.286-91 (OPS - Publicación científica, 541). 
Baltes MM, Silverberg S. A dinâmica dependencia-autonomia no curso da vida. In: Neri AL, organizadora. Psicologia do envelhecimento: temas selecionados na perspectiva de curso de vida. São Paulo: Papirus; 1995. p. 73-110.

Boff L. Saber cuidar: ética do humano - compaixão pela terra. 6. ed. Petrópolis: Vozes; 2000.

Caldas CP. Envelhecimento com dependência: responsabilidades e demandas da família. Cad Saúde Pública. 2003; 19(3):773-8.

Camarano AA. Envelhecimento da população brasileira: uma contribuição demográfica. In: Freitas EV, Py L, Néri AL, Cançado FAX, Gorzoni ML, Rocha SM. Tratado de geriatria e gerontologia. Rio de Janeiro: Guanabara; 2002. p.58.

Camarano AA, Ghaouri Sk. Famílias com idosos: ninhos vazios? Rio de Janeiro: IPEA; 2003. (Textos para Discussão, 950).

Camarano AA, Pasinato MT. O envelhecimento populacional na agenda das políticas públicas In: Camarano AA, organizadora. Os novos idosos brasileiros: muito além dos 60? Rio de Janeiro: IPEA; 2004. p.253-92.

Camarano AA, Kanso S, Mello JL. Como vive o idoso brasileiro. In: Camarano AA, organizadora. Os novos idosos brasileiros: muito além dos 60? Rio de Janeiro: IPEA; 2004. p. 25-73.

Camarano AA, Kanso S, Mello JL, Pasinato MT. Famílias: espaço de compartilhamento de recursos e vulnerabilidades. In: Camarano AA, organizadora. Os novos idosos brasileiros: muito além dos 60? Rio de Janeiro: IPEA; 2004. p. 135-67. 
Cano MAT, Ferriani MGC. A organização social da vida familiar através dos tempos. Acta Paul Enferm. 2000; 13(3):25-34.

Cardoso MHCA, Gomes R. Representações sociais e história: referenciais teóricometodológicos para o campo da saúde coletiva. Cad Saúde Pública. 2000; 16(2):499506.

Carvalho JAM, Garcia RA. O envelhecimento da população brasileira: um enfoque demográfico. Cad Saúde Pública. 2003; 19(3):725-33.

Chaimowicz F. A saúde dos idosos brasileiros às vésperas do século XXI: problemas, projeções e alternativas. Rev Saúde Pública. 1997; 31:184-200.

Debert GG. A reinvenção da velhice: socialização e processos de reprivatização do envelhecimento. São Paulo: EDUSP/Fapesp; 1999.

Debert GG. A construção e a reconstrução da velhice: família, classe social e etnicidade. In: Néri AL, Debert GG, organizadoras. Velhice e sociedade. Campinas: Papirus; 1999. p.41-68.

Derntl, AM, Almeida MHM, Castro CGJ, Litvoc J, Watanabe HAV. Projeto de assistência ao idoso no domicílio fundamentado num sistema de vigilância da incapacidade e dependência. 2002. [Projeto financiado pelo MS-Brasil].

Duarte SJH. Representação social da gestante residente no Marabá a respeito do prénatal [dissertação de mestrado em saúde coletiva]. Campo Grande: Universidade Federal do Mato Grosso do Sul, 2007.

Duarte YAO. Cuidadores de idosos: uma questão a ser avaliada. Mundo Saúde 1997; 21: 226-30. 
Duarte YAO. Família: rede de suporte ou fator estressor. a ótica de idosos e cuidadores familiares [tese de doutorado] São Paulo: Escola de Enfermagem da USP, 2001.

Duveen G. O poder das idéias: introdução. In: Moscovici S. Representações sociais: investigações em psicologia social. Petrópolis: Vozes; 2003.p. 7-28.

Erikson EH. O ciclo de vida completo: versão ampliada com novos capítulos sobre o nono estágio do desenvolvimento, por Joan M. Erikson. Porto Alegre: Artes Médicas; 1998.

Falcão DVS. Doença de Alzheimer: um estudo sobre o papel das filhas cuidadoras e suas relações familiares [tese de doutorado] Brasília: Instituto de Psicologia da Universidade de Brasília, 2006.

Falcão DVS, Dias CMSB, Buscher-Maluschke JSNF, Salomão NMR. As relações familiares entre as gerações: possibilidades e desafios In: Falcão DVS, Dias CMSB,organizadoras. Maturidade e velhice: pesquisa e intervenções psicológicas. São Paulo: Casa do Psicólogo; 2006. v. 1.

Faro ACM. Aspectos teóricos sobre a família em um contexto histórico e social. Nursing. 2000; 3(3):26-8. [edição brasileira].

Fonte IB. Diretrizes internacionais para o envelhecimento e suas conseqüências no conceito de velhice. In: Anais do 12: Encontro da Associação Brasileira Estudos Populacionais; 2002 nov 4-8; Ouro Preto, MG, Brasil. p.1-15.

Fundação SEADE. Anuário estatístico do Estado de São Paulo: Sumário dos Dados 2004; São Paulo, 2007. [acesso em 16/2/2007]. Disponível em: http://www.seade.sp.gov.br. 
Fuzikawa CS. Projeto Bambui um estudo de base populacional da confiabilidade intra e entre observadores do teste do relógio [dissertação de mestrado]. Belo Horizonte: Universidade Federal de Minas Gerais; 2002.

Goldani AM. Relações intergeracionais e reconstrução do estado de bem-estar. Por que se deve repensar essa relação para o Brasil? In: Camarano AA, organizadora. Os novos idosos brasileiros: muito além dos 60? Rio de Janeiro: IPEA; 2004. p. 211-40.

Goldenberg M. A arte de pesquisar: como fazer pesquisa qualitativa em ciências sociais. 4. ed. Rio de Janeiro: Record; 2000.

Goldstein LL, Sommerhalder C. Religiosidade, espiritualidade e significado existencial na vida adulta e velhice. In: Freitas EV, Py L, Neri AL, Cançado FAX, Gorzoni ML, Rocha SM. Tratado de geriatria e gerontologia. Rio de Janeiro: Guanabara; 2002. p. 9506.

Gonzalez TBD, Andrade AME, Vea HB. Caracterización de las relaciones familiares del anciano. Rev Cubana Med Gen Integr 2001; 17(5): 418-22.

IBGE - Instituto Brasileiro de Geografia e Estatística - Perfil dos idosos responsáveis pelos domicílios, Rio de Janeiro - 2006, p.1-8. [acesso em 12/4/2006]. Disponível em: http://www.ibge.gov.br/home/presidência/noticias/25072002pidoso.shtm.

Jodelet D. As representações sociais: um domínio em expansão. In: Jodelet D, organizadora. As representações sociais. Rio de Janeiro: Ed. UERJ; 2001. p. 17-44.

Karsch USM, organizadora. Envelhecimento com dependência: revelando cuidadores. São Paulo: EDUC; 1998. 
Karsch USM. Apoio familiar aos idosos. São Paulo; 2002. [Paper distribuído no Programa de Verão: Promoção da Saúde no Envelhecimento: contribuição da epidemiologia (PSE) da Faculdade de Saúde Pública da USP].

Lefèvre F, Lefèvre AMC, Teixeira JJV, organizadores. O discurso do sujeito coletivo: uma nova abordagem metodológica em pesquisa qualitativa. Caxias do Sul: EDUCS; 2000.

Lefèvre AMC, Lefèvre F. O discurso do sujeito coletivo: teoria e prática. São Paulo; 2002. [Apostila distribuída no Programa de Verão: Pesquisa qualitativa: novas metodologias de análise de discurso.da Faculdade de Saúde Pública da USP].

Lefèvre AMC, Lefèvre F, Cardoso MRL, Rossetto Mazza, MMP. Assistência pública à saúde no Brasil: estudo de seis ancoragens. Saúde Soc 2002; 11(2):12-5, 2005.

Lefèvre F, Lefèvre AMC. Depoimentos e discursos: uma proposta de análise em pesquisa social. Brasília: Líber Livro Editora; 2005.

Litvoc J, Derntl AM. Capacidade funcional do idoso: significado e aplicações. In: Cianciarullo TI, Gualda DMR, Silva GTR, Cunha ICKO, organizadores. Saúde na família e na comunidade. São Paulo: Robe Editorial; 2002. p. 268-318.

Lourenço RA, Ribeiro Filho ST, Irene FH, Paradela EMP, Miranda AS. O teste do desenho do relógio. desempenho entre idosos com baixa escolaridade. (Cuidado Integral à Pessoa Idosa/ Universidade Aberta da Terceira Idade / Universidade do Estado do Rio de Janeiro) (Resumo do Congresso GERP 2003).

Marques S. Cuidadores familiares de idosos: relatos de histórias [dissertação de mestrado]. Ribeirão Preto: Escola de Enfermagem da USP,1999. 
Mazzotti-Alves AJ. O debate contemporâneo sobre os paradigmas. In: Mazzotti-Alves AJ, Gewandsznajder F. O método nas ciências naturais e sociais: pesquisa quantitativa e qualitativa. 2. ed. São Paulo: Pioneira; 1999. cap. 6.

Medeiros M, Osório R. Arranjos domiciliares e arranjos nucleares no Brasil: classificação e evolução de 1977 a 1998. Brasília: IPEA; 2001. (Textos para Discussão, 788).

Medeiros M, Osório R. Mudanças nas famílias brasileiras: a composição dos arranjos domiciliares entre 1978 a 1998. Brasília: IPEA;2002. (Textos para Discussão, 886).

Medeiros M, Diniz D. A nova maneira de se entender a deficiência e o envelhecimento. Brasília: IPEA; 2004. (Textos para Discussão, 1040).

Minayo MCS, organizadora. Pesquisa social: teoria, método e criatividade. 21. ed. Petrópolis: Vozes; 2002. Ciência, técnica e arte: o desafio da pesquisa social; p. 10-25.

Mioto RCT. Famílias hoje: o começo da conversa.... Texto Contexto Enferm. 1999; 8:211-9.

Moreira ASP, Oliveira DC, organizadoras. Estudos interdisciplinares de representação social. 2. ed. Goiânia: AB editora; 2000. Apresentação; p.xii.

Moscovici S. Das representações coletivas às representações sociais: elementos para uma história. In: Jodelet D, organizadora. As representações sociais. Rio de Janeiro: Ed. UERJ; 2001. cap. 2, p. 45-66.

Mota V. Bolsa de valores. Folha de São Paulo, 2007 out 7; Família brasileira retrato falado: 16 . 
MPAS - Ministério da Previdência e Assistência Social. Secretaria de Estado e Assistência Social. Programa Nacional de Cuidadores de Idosos. Brasília (DF); 2000.

Néri AL. Palavras-chave em gerontologia. Campinas: Editora Alínea; 2001.

Neri AL, Carvalho VAML. O bem-estar do cuidador: aspectos psicossociais. In: Freitas EV, Py L, Neri AL, Cançado FAX, Gorzoni ML, Rocha SM. Tratado de geriatria e gerontologia. Rio de Janeiro: Guanabara; 2002. p. 778-90.

Nunes IA. O cuidar do idoso com trauma ortopédico realizado pelo cuidador familiar no domicílio [dissertação de mestrado]. São Paulo: Escola de Enfermagem da USP, 2002.

Organização Pan-Americana de Saúde/Organização Mundial da Saúde. 26 Conferência Sanitária Pan-Americana. Washington (DC); 2002. (54 Sessão do Comitê Regional).

Papaléo-Neto M. O estudo da velhice no século XX: histórico, definição do campo e termos básicos. In: Freitas EV, Py L, Neri AL, Cançado FAX, Gorzoni ML, Rocha SM. Tratado de geriatria e gerontologia. Rio de Janeiro: Guanabara; 2002. p.2-12.

Paschoal SMP. Qualidade de vida na velhice. In: Freitas EV, Py L, Neri AL, Cançado FAX, Gorzoni ML, Rocha SM. Tratado de geriatria e gerontologia. Rio de Janeiro: Guanabara; 2002. p. 79-84.

Ramos LR. Epidemiologia do envelhecimento. In: Freitas EV, Py L, Neri AL, Cançado FAX, Gorzoni ML, Rocha SM. Tratado de geriatria e gerontologia. Rio de Janeiro: Guanabara; 2002. p. 72-8.

Ramos LR. Fatores determinantes do envelhecimento saudável em idosos residentes em centro urbano: projeto epidoso, São Paulo. Cad Saúde Publica. 2003; 19(3):793-8. 
Rodrigues NC, Rauth J. Os desafios do envelhecimento no Brasil. In: Freitas EV, Py L, Neri AL, Cançado FAX, Gorzoni ML, Rocha SM. Tratado de geriatria e gerontologia. Rio de Janeiro: Guanabara; 2002. p.106-10.

Rossetto Mazza MMP. Cuidar em família: análise da representação social da relação do cuidador familiar com o idoso [dissertação de mestrado]. São Paulo: Faculdade de Saúde Pública da USP; 2002.

Saad PM. Transferência de apoio intergeracional no Brasil e na América Latina. In: Camarano AA, organizadora. Os novos idosos brasileiros: muito além dos 60 ? Rio de Janeiro: IPEA; 2004. p. 169-212.

Sanches MAS. A dependência e suas implicações para a perda da autonomia: estudo das representações para idosos de uma unidade ambulatorial geriátrica. Textos Envelhecimento. 2000; 3(3):35-54.

Santos SMA. Idosos, familia e cultura: um estudo sobre a construção do papel do cuidador. Campinas: Ed. Alínea; 2003.

Sayão R. De geração em geração. Folha de São Paulo, 2007 jun 14; Equilibrio:12.

Simioni AMC et al. Metodologia qualitativa nas pesquisas em saúde coletiva: considerações teóricas e instrumentais. São Paulo: Departamento de Prática de Saúde Pública da Faculdade de Saúde Pública da USP; 1997.( Série Monográfica do HSP, 2).

USP/FSP/HSP - Universidade de São Paulo. Faculdade de Saúde Pública. Departamento de Prática de Saúde Pública. Projeto Capacidade: Programa de Assistência ao Idoso no Domicílio fundamentado num sistema de vigilância à incapacidade funcional e dependência. São Paulo; 1998-2001. 
Velásquez MD, Dal Rio MC, Marques DD, Medeiros SAR. As trajetórias de vida dos cuidadores principais. In: Karsch UMS, organizadora. Envelhecimento com dependência: revelando cuidadores. São Paulo: EDUC; 1998 p. 87-145.

Veras R. Em busca de uma assistência adequada à saúde do idoso: revisão da literatura e aplicação de um instrumento de detecção precoce e de previsibilidade de agravos. Cad Saúde Pública. 2003; 19(3):705-15.

Wagner W. Sócio-gênese e características das representações sociais. In: Moreira ASP, Oliveira DC, organizadoras. Estudos interdisciplinares de representação social. 2. ed. Goiânia: AB Editora; 2000. p.3-25.

Wanderley MB, coordenador. A publicização do papel dos cuidadores domiciliares: uma questão em debate. São Paulo: Instituto de Estudos Especiais - PUC; 1998.

Watson YL, Arkfen CL, Birge SJ. Clock completion: an objective screening test for dementia. J Am Geriatr Soc. 1993;41(11):1235-40. 


\section{BIBLIOGRAFIA COMPLEMENTAR}

Beauvoir S. A velhice. Rio de Janeiro: Nova Fronteira; 1990.

Fuster AB. Aspectos psicológicos del envejecimento. In: Organización Panamericana de Salud. La atención de los ancianos: un desafio para los años noventa. Washington (DC); 1994. p.67-73. (OPS - Publicación Científica, 546).

Imbassahy M. O cuidado em uma relação muito delicada. Textos Envelhecimento 2000; 3(4):7-12.

Kalache A. ? Qué repercusiones tiene el envejecimento de la populación en el futuro previsible? In: Organización Panamericana de Salud. La atención de los ancianos: un desafio para los años noventa. Washington (DC); 1994. p.453-67. (OPS - Publicación Científica, 546).

Leitão GCM, Almeida DT da. O cuidador e sua qualidade de vida. Acta Paul Enferm. 2000; 13:80-5.

Leme LEG. A gerontologia e o problema do envelhecimento: visão histórica. In: Papaléo Neto M, organizador. Gerontologia. São Paulo: Atheneu; 1996. p.13-25.

MPAS - Ministério da Previdência e Assistência Social. Secretaria de Estado e Assistência Social. Idosos: problemas e cuidados básicos. Brasília (DF); 1999.

Quintero OM. El autocuidado. In: Organización Panamericana de la Salud. La atención de los ancianos: un desafio para los años noventa. Washington (DC); 1994. p.352-59. (OPS - Publicación Científica, 546). 
Restrepo HE, Pérez EA. Promoción de la salud de los ancianos. In: Oranizacion Panamericana de la Salud. La atención de los ancianos: un desafio para los años noventa. Washington (DC); 1994. p.383-88. (OPS - Publicación Científica, 546).

Rodrigues RAP, Diogo MJD, organizadores. Como cuidar dos idosos. Campinas: Papirus; 1996.

Silva EBN, Neri AL. Questões geradas pela convivência com idosos: indicações para programas de suporte familiar. In: Neri AL, organizador. Qualidade de vida e idade madura. Campinas: Papirus; 1993. p. 213-36.

Silva MJP da. O amor é o caminho:maneiras de cuidar. São Paulo: Editora Gente; 2000.

Teixeira INAO. Definições de fragilidade em idosos: uma abordagem multidisciplinar. [dissertação de mestrado]. Campinas: Faculdade de Educação da UNICAMP; 2006.

Volich RM. O cuidar e o sonhar Mundo Saúde 2000; 24:237-45. 


\section{ANEXO 1 \\ TERMO DE CONSENTIMENTO LIVRE E ESCLARECIDO}

O presente estudo objetiva conhecer o que pensa o idoso com 70 anos e/ou mais, portador de alguma forma de dependência física, sobre o cuidado que a ele é prestado pelo seu cuidador familiar, e qual a sua percepção sobre esse cuidado.

A população do estudo é de idosos matriculados no Centro de Saúde Escola Geraldo de Paula Souza da Faculdade de Saúde Pública da USP.

A coleta de dados será realizada através de entrevistas individuais e gravadas no domicílio desses idosos e cuidadores.

Será garantido o anonimato do(a) entrevistado(a) e a confidencialidade das informações. A participação não é obrigatória ficando o entrevistado(a) livre para desistir a qualquer momento.

A pesquisadora compromete-se a esclarecer todas as dúvidas acerca da pesquisa, assim como a divulgar os resultados para as pessoas que desejarem.

Isto posto, declaro que, após ter sido convenientemente esclarecido(a) pela pesquisadora, que aceito participar desta pesquisa, estando ciente de que, com minha autorização, a entrevista será gravada.

São Paulo, de de 2005

assinatura do participante

assinatura da pesquisadora 


\section{ANEXO 2}

\section{ROTEIRO DE ENTREVISTA}

Nome do idoso(a):

Endereço:

Tel:. data de nascimento:

Sexo: escolaridade:

Morbidade e incapacidade:

Relação de parentesco com o cuidador:

Quem é o provedor da família:

Teste O'Clock.

Escala de Akhtar.

\section{QUESTÕES}

$1 \mathrm{O} / \mathrm{A} \mathrm{Sr}$ (a) é cuidado(a) pelo(a). ele(a) é um bom cuidador(a)? (pausa) Fale um pouquinho para mim sobre isso.

2. Como seria se o/a sr(a) não estivesse sendo cuidado pelo(a) ?

3. O(A) sr(a) acha que além da(o) .......... precisaria de mais alguém para cuidar do sr(a)? Por quê? (se houver necessidade) 


\section{ANEXO 3}

TESTE O`CLOCK

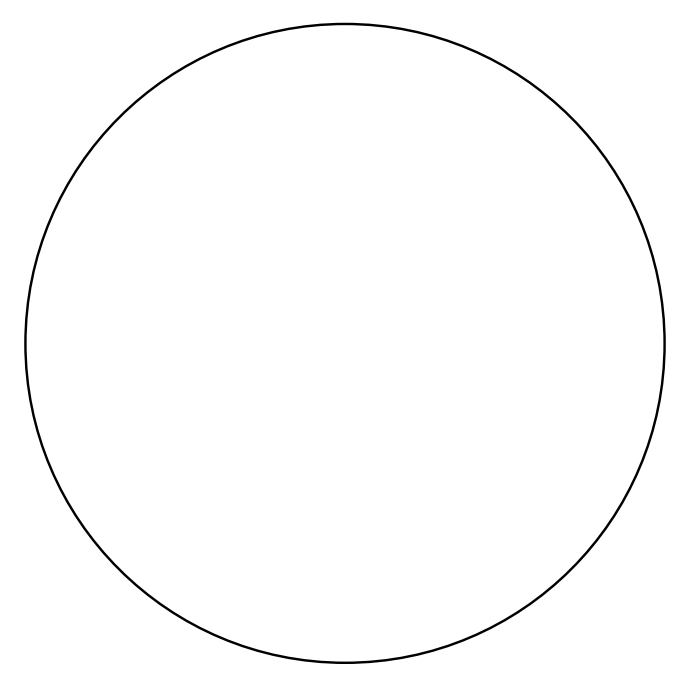





\section{Ficha de Identificação}

Data da entrevista: _____ Nome do entrevistador:

Horário de início:

Nome do idoso: $\mathrm{FF}$

Endereço: Tel. :

Data de Nascimento:

Sexo:

Estado civil:

Mora só? Sim ( ) Não ( )

Quantas pessoas têm no domicílio ?

E quantos idosos incluindo o idoso ?

O idoso tem filhos, independente de morarem com ele ? Sim ( ) Não ( ) Quantos?

Em caso de necessidade, quem o (a) ajuda? Ninguém ( )

Caso haja pessoas que ajudem o (a) idoso(a), preencher quadro abaixo. Cada linha destina-se a uma pessoa

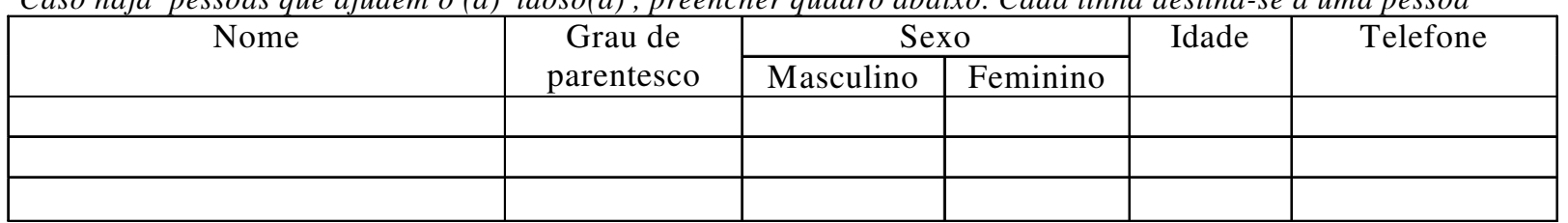

Propriedade da moradia

( ) própria, do idoso ( ) própria, de familiares que moram junto

( ) alugada ( ) cedida ( ) outra

Tipo de moradia
( ) casa
( ) apartamento
( ) outro tipo

Freqüentou escola? Sim ( ) Não ( ) Quantos anos estudou?

Qual profissão que o idoso considera como a principal em sua vida?

Exerce essa profissão atualmente? Sim ( ) Não ( )

Se o (a) idoso (a) não exerce a profissão atualmente, aplicar a questão abaixo

Ganha dinheiro com algum outro trabalho atualmente? ( ) Sim ( ) Não.

Qual ?

Realiza algum trabalho voluntário? Sim ( ) Não ( ) Qual?

Quais são seus recursos financeiros atualmente?

Assinale com um $X$ os recursos financeiros do (a) idoso (a) (múltipla escolha)

A poupança é considerada recurso se o (a) idoso(a) tira dinheiro da poupança para as suas despesas

\begin{tabular}{|l|l|}
\hline Salário & \\
\hline Aposentadoria & \\
\hline Pensão & \\
\hline Benefício assistencial & \\
\hline Aluguel & \\
\hline Atividades informais & \\
\hline Poupança & \\
\hline Recebe ajuda em dinheiro ou espécie & \\
\hline
\end{tabular}

Com sua situação econômica como satisfaz suas necessidades de alimentação, moradia, saúde, etc?

Assinale com um X a forma com o (a) idoso (a) retirar satisfaz suas necessidade

\begin{tabular}{|l|l|}
\hline Muito bem & \\
\hline Bem & \\
\hline Mal & \\
\hline Muito mal & \\
\hline
\end{tabular}

Segue alguma religião? Sim ( ) Não ( ) Qual?

Possui convênio de saúde. Sim $\quad(\quad$ Não $\quad(\quad$ Qual?

Faz parte de algum grupo de Terceira idade? ( ) Sim ( ) Não.

Gostaria de participar de um grupo do CSE? ( ) Sim ( ) Não 


\begin{tabular}{|c|c|c|c|c|}
\hline \multirow{2}{*}{\multicolumn{2}{|c|}{ MOBILIDADE }} & $\begin{array}{l}\text { (1) movimenta-se completamente } \\
\text { (2) movimenta-se dentro e fora de casa com dificuldade }\end{array}$ & & \\
\hline & & $\begin{array}{l}\text { (3) movimenta-se em casa sem ajuda } \\
\text { (4) movimenta-se em casa com aparelho, sem ajuda } \\
\text { (5) movimenta-se com ajuda } \\
\text { (6) permanece no leito ou em cadeira de rodas }\end{array}$ & & \\
\hline \multirow{2}{*}{\multicolumn{2}{|c|}{$\begin{array}{l}\text { CONTROLE DE } \\
\text { ELIMINAÇÕES }\end{array}$}} & $\begin{array}{l}\text { (1) continência completa } \\
\text { (2) incontinência ocasional ou incontinência por estresse }\end{array}$ & & ) \\
\hline & & $\begin{array}{l}\text { (3) incontinência urinária noturna } \\
\text { (4) incontinência urinária diurna e noturna } \\
\text { (5) incontinência urinária e fecal }\end{array}$ & & \\
\hline \multirow[t]{4}{*}{ AIVDs } & COZINHAR & $\begin{array}{l}\text { (1) capaz de preparar todas as refeições } \\
\text { (2) capaz de preparar alguns mas não todos os alimentos } \\
\text { (3) incapaz de preparar alimentos/refeições }\end{array}$ & ( & ) \\
\hline & $\begin{array}{l}\text { TRABALHOS } \\
\text { DOMÉSTICOS }\end{array}$ & $\begin{array}{l}\text { (1) capaz de realizar todos os trabalhos domésticos } \\
\text { (2) requer ajuda para trabalhos domésticos } \\
\text { (3) requer ajuda em tempo integral }\end{array}$ & ( & ) \\
\hline & COMPRAS & $\begin{array}{l}\text { (1) capaz de fazer todas as compras } \\
\text { (2) requer ajuda com as compras } \\
\text { (3) incapaz de fazer compras }\end{array}$ & ( & ) \\
\hline & $\begin{array}{l}\text { LAVAR E PAS- } \\
\text { SAR ROUPAS }\end{array}$ & $\begin{array}{l}\text { (1) capaz de cuidar de todas as roupas } \\
\text { (2) requer ajuda para cuidar das roupas } \\
\text { (3) incapaz de cuidar das roupas }\end{array}$ & & ( \\
\hline \multirow{2}{*}{\multicolumn{2}{|c|}{$\begin{array}{l}\text { AVALIAÇÃO } \\
\text { DAS AIVDs }\end{array}$}} & $\begin{array}{l}\text { (1) pontuação } 1 \text { em todas as atividades } \\
\text { (2) pontuação } 2 \text { em não mais do que uma atividade }\end{array}$ & ( & ) \\
\hline & & $\begin{array}{l}\text { (3) pontuação } 2 \text { em duas ou mais atividades ou } 3 \text { em uma atividade } \\
\text { (4) pontuação } 3 \text { em duas ou mais atividades }\end{array}$ & & \\
\hline \multirow[t]{3}{*}{$\begin{array}{l}\text { AUTO- } \\
\text { CUIDADO }\end{array}$} & VESTIR & $\begin{array}{l}\text { (1) independente } \\
\text { (2) requer ajuda apenas para calçar sapatos e meias } \\
\text { (3) capaz de ajudar no vestir-se } \\
\text { (4) incapaz de ajudar no vestir-se }\end{array}$ & & ) \\
\hline & ALIMENTAÇÃO & $\begin{array}{l}\text { (1) independente } \\
\text { (2) requer ajudar apenas para cortar alimentos } \\
\text { (3) capaz de ajudar na sua alimentação } \\
\text { (4) incapaz de ajudar na sua alimentação }\end{array}$ & & ) \\
\hline & ELIMINAÇÕES & $\begin{array}{l}\text { (1) independente dia e noite } \\
\text { (2) requer ajuda apenas à noite } \\
\text { (3) requer alguma ajuda mas permanece continente } \\
\text { (4) incontinente a despeito da ajuda }\end{array}$ & & ) \\
\hline \multirow{2}{*}{\multicolumn{2}{|c|}{$\begin{array}{l}\text { AVALIACCÃO DO } \\
\text { AUTOCUIDADO }\end{array}$}} & $\begin{array}{l}\text { (1) totalmente independente, pontuação } 1 \text { em todas as atividades } \\
\text { (2) incapacidade mínima, pont. } 1 \text { em todas atividades exceto vestir-s }\end{array}$ & $\begin{aligned}( \\
\text { e com }\end{aligned}$ & $\begin{array}{c}\text { ) } \\
\text { pont.2 }\end{array}$ \\
\hline & & $\begin{array}{l}\text { (3) independência parcial, pont. } 2 \text { ou } 3 \text { na alimentaç. e eliminação ou } \\
\text { (4) dependente: pontuação } 4 \text { em uma das atividades } \\
\text { (5) totalmente dependente: pontuação } 4 \text { em duas ou mais atividades }\end{array}$ & & estir \\
\hline
\end{tabular}




\begin{tabular}{|c|c|c|}
\hline \multirow[t]{6}{*}{ AIVDs } & TELEFONAR & $\begin{array}{l}\text { (1) Independente tanto para atender ao telefone quanto para } \\
\text { procurar o número na lista ou discar } \\
\text { (2) Atende ao telefone mas requer ajuda para procurar o número na lista e/ou } \\
\text { discar } \\
\text { (3) Incapaz de usar o telefone }\end{array}$ \\
\hline & $\begin{array}{l}\text { TOMAR } \\
\text { REMÉDIOS } \\
\text { RECEITADOS }\end{array}$ & $\begin{array}{l}\text { (1) Independente (na identificação do remédio, dosagem e horário) ( } \\
\text { (2) Requer ajuda no preparo do remédio ou necessita ser lembrado de tomá-lo } \\
\text { (3) incapaz de tomar os remédios por si }\end{array}$ \\
\hline & $\begin{array}{l}\text { ADMINISTRAR } \\
\text { AS PRÓPRIAS } \\
\text { FINANÇAS }\end{array}$ & $\begin{array}{l}\text { (1) Independente para receber pagamentos, pagar contas e controlar } \\
\text { o orçamento } \\
\text { (2) Requer alguma ajuda na administração das próprias finanças } \\
\text { (3) Incapaz de administrar as próprias finanças }\end{array}$ \\
\hline & $\begin{array}{l}\text { USO DE MEIOS } \\
\text { DE TRANSPOR- } \\
\text { TE }\end{array}$ & $\begin{array}{l}\text { (1) independente para usar } \\
\text { (2) requer ajuda para usar } \\
\text { (3) incapaz de usar }\end{array}$ \\
\hline & $\begin{array}{l}\text { AVALIAÇÃO } \\
\text { DAS AIVDs }\end{array}$ & $\begin{array}{l}\text { (1) pontuação } 1 \mathrm{em} \text { todas as atividades } \\
\text { (2) pontuação } 2 \mathrm{em} \text { não mais do que uma atividade }\end{array}$ \\
\hline & & $\begin{array}{l}\text { (3) pontuação } 2 \text { em duas ou mais atividades ou } 3 \text { em uma atividade } \\
\text { (4) pontuação } 3 \text { em duas ou mais atividades }\end{array}$ \\
\hline \multirow[t]{2}{*}{\begin{tabular}{|l|l} 
AUTO \\
CUIDADO
\end{tabular}} & \multirow[t]{2}{*}{$\begin{array}{l}\text { TOMAR } \\
\text { BANHO }\end{array}$} & \begin{tabular}{|l} 
(1) Independente \\
(2) Requer ajuda apenas para lavar uma parte do corpo como costas ou pernas
\end{tabular} \\
\hline & & $\begin{array}{l}\text { (3) Requer ajuda para lavar mais que uma parte do corpo } \\
\text { (4) Incapaz de ajudar no banhar-se }\end{array}$ \\
\hline
\end{tabular}

Teve alguma queda nos últimos 6 meses? ( ) sim ( ) não 